\title{
MARKOVIĆEVA KRITIKA HEGELOVE LOGIKE ${ }^{1}$
}

\begin{abstract}
Rukopisna Logika Franje pl. Markovića (1845. - 1914.), prvoga profesora filozofije na obnovljenome Zagrebačkome sveučilištu (1874.), čuva se u Arhivu Hrvatske akademije znanosti i umjetnosti u Zagrebu, i to autograf pod oznakom XV 37/1, a pod oznakom XV 37/2 šest litografiranih primjeraka ( $a-f)$, od kojih je najopsežniji onaj s oznakom $2 a$ (obaseže oko 820 stranica). Marković je logiku predavao »ciklički«, od 1875., pa sve do 1907., dakle pune 32 godine. Rukopis se Logike, grubo uzevši, sastoji od dvaju dijelova: prvi je uvodni, a drugomu je naslov Sustav logike. Prvi se dio potom dijeli na sedam, a drugi dio na jedanaest odsjeka. U članku se razmatra šesti odsjek prvoga (uvodnoga) dijela pod naslovom Razlozi proti absolutnoj logici (u primjerku 2a str. 94-119), u kojem Marković iznosi svoju kritike Hegelove logike. Pri tome se najprije opisuje sam rukopis Logike, a potom se Marković dovodi u vezu s filozofskim i duhovnim okružjem u drugoj polovici 19. stoljeća. Zatim se raspravlja o dvama osnovnim Markovićevim prigovorima Hegelu: prvo, da nije moguće iz jednoga (najapstraktnijega) pojma, koji bi bio početak svih ostalih pojmova, razviti sveukupnost pojmova (te ujedno sveukupnost cjeline svega što jest) bez pomoći opažajnih pomisli; i drugo, da je postupak apsolutne logike sam u sebi »nelogičan«, tj. protivan neoborivim zakonima logike. Na kraju se zaključuje da Marković Hegelovu logiku, koja je zapravo metafizika, kritizira isključivo iz logičkoga obzora, jer ne prihvaća »pretvorbu« logike u metafiziku. Posebno se ističe Markovićeva namjera da se (filozofski) »odredi« prema Hegelu, jer se mnogi protivnici Hegelova filozofiranja, kojima i sam pripada, uglavnom nerado bave Hegelovom filozofijom. U Dodatku se donosi taj šesti odsjek uvodnoga dijela Markovićeve Logike u prijepisu.

Ključne riječi: Franjo Marković; logika; Georg Wilhelm Friedrich Hegel; kritika Hegelove logike; protuhegelovstvo; Robert Zimmermann; Friedrich Adolf Trendelenburg; aristotelizam; Franz Brentano; austrijski realizam.
\end{abstract}

\section{O Markovićevoj Logici}

U Arhivu Hrvatske akademije znanosti i umjetnosti u Zagrebu čuva se rukopis Logike hrvatskoga filozofa, klasičnoga filologa, književnika, kazališnoga i književnoga kritičara Franje pl. Markovića (1845. - 1914.), i to autograf (koji je vrlo

\footnotetext{
Ovaj je rad financirala Hrvatska zaklada za znanost projektom IP-2016-06-6762.
} 
teško čitliv) pod oznakom XV 37/1, a pod oznakom XV 37/2 šest litografiranih primjeraka $(a-f)$, od kojih je najopsežniji onaj s oznakom $2 a$ (obaseže oko 820 stranica). Svi su litografirani primjerci vrlo čitljivi. U svakome se od njih nalaze Markovićevi ispravci, no uzajamno se razlikuju po potpunosti te po količini navedenih ispravaka. Potonjih ima najviše u primjercima $a, b$ i $c$. Svi su ispravci i dopune pisani Markovićevom rukom. ${ }^{2}$

Marković je logiku predavao od 1875. (prvo je predavanje održao 18. listopada), ${ }^{3}$ pa sve do godine 1907., dakle pune 32 godine, »ciklički«, u pravilnim razmacima od po dviju ili triju godina, i to kako slijedi: ${ }^{4}$

- u zimskome poljeću ${ }^{5}$ 1875./1876. (4 sata tjedno)

- u ljetnome poljeću 1876. (2 sata tjedno)

- u zimskome poljeću 1877./1878. (5 sati tjedno)

- u ljetnome poljeću 1877./1878. (1 sat tjedno; »Logičke vježbe za kandidate«)

- u zimskome poljeću 1880./1881. (7 sati tjedno) ${ }^{6}$

- u zimskome poljeću 1883./1884. (6 sati tjedno)

- u ljetnome poljeću 1883./1884. (2 sata tjedno; nastavak i završetak)

- u zimskome poljeću 1885./1886. (4 sata tjedno)

- u ljetnome poljeću 1885./1886. (3 sata tjedno)

- u zimskome poljeću 1887./1888. (4 sata tjedno)

- u ljetnome poljeću 1887./1888. (2 sata tjedno; nastavak i završetak)

- u zimskome poljeću 1890./1891. (4 sata tjedno)

- u ljetnome poljeću 1890./1891. (3 sata tjedno; nastavak)

- u zimskome poljeću 1891./1892. (2 sata tjedno; »Njeke odabrane česti iz logike«)

- u ljetnome poljeću 1891./1892. (3 sata tjedno; »Njeke odabrane česti iz logike«; završetak)

- u zimskome poljeću 1894./1895. (5 sati tjedno)

2 Općenito o rukopisnoj ostavštini Franje pl. Markovića vidi Bojan Marotti, O Markovićevim filozofskim rukopisima u arhivima HAZU, u časopisu Civitas Crisiensis, vol. 2., 2016., str. 109-152.

3 Vidi u primjerku $2 a$ prvu stranicu, gdje u zagradi piše ovako: (Uvodno predavanje još od 18. listopada 1875.), što je potom precrtano.

4 Navodim prema Ivan Peklić, Život i djelo Franje Markovića, Hrvatska akademija znanosti i umjetnosti - Zavod za znanstveno-istraživački rad Koprivničko-križevačke županije u Križevcima, Zagreb - Križevci, 2014., str. 49-54.

5 Riječ poljeće znači 'semestar', 'polugodište'. Česta je u Markovića. Vidi npr. Dragutin Parčić, Vocabolario croato-italiano, terza edizione corretta ed aumentata, Tipografia editrice »Narodni List«, Zara, 1901., str. 691 (pretisak: ArTresor studio, Zagreb, 1995.), ili Julije Benešić, Rječnik hrvatskoga književnoga jezika, sv. 10., za tisak priredili Josip Hamm, Milan Moguš, Josip Vončina, Jugoslavenska akademija znanosti i umjetnosti, Zagreb, 1989., str. 2167. Benešić ima naglasak pòljeće, a navodi za tu riječ dvije potvrde, jednu iz djela Ante Kovačića, a drugu iz djela Vjenceslava Novaka.

6 U tome je poljeću prema tome predavao samo logiku. 
- u ljetnome poljeću 1894./1895. (6 sati tjedno)

- u zimskome poljeću 1896./1897. (3 sata tjedno)

- u ljetnome poljeću 1896./1897. (3 sata tjedno; nastavak)

- u zimskome poljeću 1897./1898. (3 sata tjedno; završetak)

- u ljetnome poljeću 1899./1900. (4 sata tjedno)

- u zimskome poljeću 1900./1901. (4 sata tjedno; nastavak)

- u ljetnome poljeću 1900./1901. (3 sata tjedno; završetak)

- u zimskome poljeću 1902./1903. (4 sata tjedno)

- u ljetnome poljeću 1902. /1903. (5 sati tjedno; završetak)

- u zimskome poljeću 1905./1906. (2 sata tjedno; »Izabrane česti logike«)

- u ljetnome poljeću 1905./1906. (3 sata tjedno; »Izabrane česti logike«; nastavak)

- u zimskome poljeću 1906./1907. (3 sata tjedno; »Izabrane česti logike«)

- u ljetnome poljeću 1906./1907. (3 sata tjedno; »Izabrane česti logike«; završetak).

Kada je počeo predavati logiku, Marković je zacijelo već tada svoja predavanja imao u nekome obliku zapisana. No taj je osnovni ili, recimo, jezgreni oblik postupno proširivao i nadopunjavao različitim dodatcima i umetcima, što se jasno vidi po pozivanju na pojedina djela, među kojima se gdjekada pojave i ona objavljena nakon 1900. Zbog toga su ta predavanja s vremenom rasla te su napokon dostigla navedenih (oko) 820 rukopisnih stranica, s jasnim naznakama da ih je Marković namjeravao objaviti.?

\footnotetext{
Općenito o Markovićevu životu i radu vidi u spomenutoj monografiji Ivana Peklića Život i djelo Franje Markovića, posebice str. 11-42. Vidi također: Vjekoslav Klaić, Dr. Franjo Marković, u časopisu Vienac, god. 16., br. 21. (str. 335-337), br. 24. (str. 384-386), br. 38. (str. 608-611), 1884.; Branko Vodnik, Franjo Marković, u časopisu Savremenik, god. 1., knj. 2. (str. 81-96), knj. 3. (str. 161-178), 1906.; Ljuboje Dlustuš, Dr. Franjo Marković: Njegov život i rad, Izvanredno izdanje Kluba hrvatskih književnika u Osijeku, Osijek, 1915.; Krsto Pavletić, Život i pjesnička djela Franje Markovića, Matica hrvatska, Zagreb, 1917; potom poznatu raspravu: Albert Bazala, Filozofijski portret Franje Markovića, u Radu JAZU, knj. 224., 1921., str. 221-312 (kao knjiga: Albert Bazala, Filozofijski portret Franje Markovića, Institut za filozofiju Sveučilišta u Zagrebu, Zagreb, 1974.); zatim Antun Barac, Članak o Franji Markoviću, u knjizi Članci o književnosti, Binoza, Zagreb, 1935., str. 9-52; Ivan Čehok, Franjo Marković, u knjizi: Franjo Zenko, Novija hrvatska filozofija, Školska knjiga, Zagreb, 1995., str. 31-45 (Hrestomatija filozofije, sv. 10.); Vladan Švacov, Franjo Marković, u časopisu T \& T, god. 1., br. 2., 1995., str. 27-47; Srećko Kovač, Die kroatische Philosophie des 19. Jahrhunderts, Č učić und Marković: Ein Überblick, u knjizi: Jure Zovko (Hrsg.), Kroatische Philosophie im europäischen Kontext, Gardez! Verlag, Sankt Augustin, 2003., str. 93-110; Valentina Papić Bogadi - Ivan Peklić, Kazališna umjetnost i Franjo Marković, s posebnim osvrtom na recepciju u novinama na njemačkom jeziku, u časopisu Podravina, god. 11., br. 21., 2012., str. 77-97, posebice str. 77-85. Vidi k tomu i Bojan Marotti, Franjo pl. Marković, pogovor knjizi: Franjo pl. Marković, Etika, kritičko izdanje priredio i pogovor napisao Bojan Marotti, Matica hrvatska, Zagreb, 2016., str. 199-241, posebice str. 199-205, kao i moju neveliku leksikografsku jedinicu o Markoviću u Filozofskome leksikonu (glavni urednik Stipe Kutleša, Leksikografski zavod »Miroslav Krleža«, Zagreb, 2012., str. 725-726).
} 
Markovićevu Logiku, grubo uzevši, čine dva dijela: prvi je uvodni, a drugomu je dijelu naslov Sustav logike. Uvodni se ili prvi dio potom dijeli na sedam, a drugi dio na jedanaest odsjeka. Evo od kojih se sedam odsjeka sastoji uvodni dio ( $u$ uglatim zagradama navodim stranice u litografiranome primjerku $2 a$ ):

- I. odsjek. [str. 1-21]

- Drugi odsjek. Razlozi proti čistoj ili pukoj formalnoj logici. [str. 22-44]

- Treći odsjek. Obrana čisto formalne logike nedostatna. [str. 44-49]

- Četvrti odsjek. Primicanje čiste formalne logike realnoj ili objektivnoj. [str. 49-61]

- Peti odsjek. Zadatak logike po valjanom njezinom pojmu, t. j. logike k jednu deduktivne (formalne) i induktivne (realne), pak razmedje njezino prama metafizici, psihologiji i prama posebnim stvarnim znanostim. [str. 61-94]

- Šesti odsjek. Razlozi proti absolutnoj logici. [str. 94-119]

- VII. odsjek. Psihologijska podloga logici. [str. 119-154]

\section{Filozofsko i duhovno okružje Franje pl. Markovića}

Premda je dakle kritiku Hegelove »absolutne« logike Marković iznio u šestome odsjeku, pa je taj odsjek pravi predmet ovoga rada, ${ }^{8}$ stanovitu najavu te kritike nalazimo već u petome odsjeku toga uvodnoga dijela. ${ }^{9}$ Naime $\mathrm{u}$ tome odsjeku Marković postavlja pitanje koji je, kako veli, »valjan smjer logike«, te ujedno na to pitanje pruža i odgovor, pa kaže da je to onaj »koji ide po sriedi medju čisto-

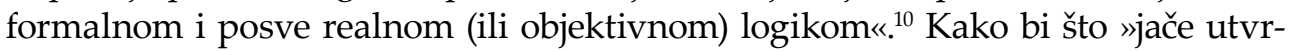
dio« da je upravo to »valjan smjer«, Marković se pozivlje na logička djela Johna

8 U Dodatku donosim taj odsjek u prijepisu. Pri tome u kosim zagradama navodim broj stranice u izvorniku (tj. u litografiranome primjerku 2a).

9 Iz Markovićeve su rukopisne Logike dosad objavljena četiri ulomka. Dva je priredio Srećko Kovač, i to: Logika, u časopisu Prilozi za istraživanje hrvatske filozofske baštine, god. 18., br. 35. - 36., 1992., str. 247-258, te Vrsti sudova po njihovih oblicih, u istome časopisu, god. 19., br. 37. - 38., 1993., str. 251-265. Preostala sam dva priredio kao posebne priloge uz dva svoja članka, i to: Psihologijska podloga logici, u zborniku Filozofijsko djelo Franje pl. Markovića, priredio Stipe Kutleša, Matica hrvatska, Zagreb, 2016., str. 101-130 (to je sedmi odsjek uvodnoga dijela), te O riečih, u spomenutome časopisu Civitas Crisiensis, vol. 2., 2016., str. 125-147 (to je prvi odsjek Sustava logike). Sto se pak tiče ostaloga dijela Markovićeve ostavštine, iz posebnoga rukopisa Uvod u pedagogiku objavljena su dosad dva ulomka. Priredio ih je Ivan Čehok, i to: Uvod u pedagogiku, u knjizi: Franjo Zenko, Novija hrvatska filozofija, Školska knjiga, Zagreb, 1995., str. 115-121 (Hrestomatija filozofije, sv. 10.), te Sustav općenite pedagogike, $\mathrm{u}$ istoj knjizi, str. 122-128. Objavljen je i rukopis pod naslovom Posebna gimnazijska pedagogika, a priredio ga je Ante Bežen, i to pod naslovom: Gimnazijska pedagogika Franje Markovića (prvotisak prema izvornom rukopisu), u časopisu Napredak, god. 149., br. 3., 2008., str. 351-368. 
Stuarta Milla (1806. - 1873.), ${ }_{1}^{11}$ Alexandera Baina (1818. - 1903.) ${ }^{12}$ i Guillaumea Tiberghiena (1819. - 1901.). ${ }^{13}$ A njima valja pridodati i spomenuti predgovor Gabriela Compayréa francuskomu prijevodu Bainove Logike. Marković dakle u petome odsjeku nastoji održati taj »srednji« smjer, ili put, između posve formalne i posve realne logike, ne priklanjajući se nijednoj od tih dviju skrajnosti. ${ }^{14}$ Stoga, nakon potankih razmatranja navedenih filozofa i njihovih stajališta, sam zaključuje ovako (str. 92):

»Poslije razgleda, izvedenoga $\mathrm{u}$ ovom odsjeku, naziramo osnovanost onakove logike, koja nije čisto formalna, t. j. koja se ne steže na motrenje samih oblikâ misli, oblikâ čistih, podpuno odlučenih od sadržine stvarne, nego se uz oblike mislene obazira i na stvarne sadržine tih oblika, logika dakle, koja se obzire na stvarnu zbiljnost, a ta nije puka formalna, nego je formalno-objektivna, oblikovno-predmetna, ali tako, da je logici obzir na predmete samo radi veće jasnoće oblikâ mislenih potreban, a ne upušta se ona u spoznavanje samih predmeta; s toga ostaje ona ipak formalnom, obćenitom, odlučenom (abstraktnom) znanošću, te je tako razmedjena od posebnih predmetnih (objektivnih) znanosti.«

$\overline{11}$ Znamenitu Millovu logiku, koja je pod naslovom A System of Logic, Ratiocinative and Inductive, Being a Connected View of the Principles of Evidence, and the Methods of Scientific Investigation objavljena u dva sveska 1843. (John W. Parker, West Strand, London), Marković navodi u njemačkome prijevodu J. Schiela, također u dva sveska. Vidi John Stuart Mill, System der deductiven und inductiven Logik: Eine Darlegung der Principien wissenschaftlicher Forschung, insbesondere der Naturforschung, in's Deutsche übertragen von J. Schiel, Dritte deutsche, nach der fünften der Originals erweiterte Auflage, Druck und Verlag von Friedrich Vieweg und Sohn, Braunschweig, 1868.

Škotski filozof Alexander Bain bio je profesor logike na Sveučilištu u Aberdeenu. Poznat je kao utemeljitelj časopisa Mind. Njegovo djelo Logic, objelodanjeno 1870. (Longmans, Green, Reader, \& Dyer, London) u dva sveska, od kojih je prvomu naslov Deduction, a drugomu Induction, Marković navodi u francuskome prijevodu Gabriela Compayréa (1843. - 1913.), koji je objavljen također u dva sveska. Vidi Alexander Bain, Logique: Déductive et inductive, traduit de l'anglais par Gabriel Compayré, Librairie Germer-Baillière, Paris, 1875., sv. 1. Déduction, sv. 2. Induction. Compayré je bio profesor filozofije na Sveučilištu u Toulouseu. Posebno se je bavio filozofijom odgoja i pedagogijom. Prijevodu Bainove Logike dodao je svoj predgovor (Préface du traducteur, sv. 1., str. V-XL), na koji se Marković također u znatnoj mjeri oslanja.

13 Belgijski filozof Guillaume Tiberghien bio je profesor filozofije na Sveučilištu u Bruxellesu. Godine 1865. objavio je knjigu Logique: La science de la connaissance (Librairie internationale, Paris - A. Lacroix, Verboeckhoven et $\mathrm{C}^{\mathrm{ie}}$, Bruxelles - Livourne - Leipzig), i to prvi (i ujedno jedini) dio pod naslovom Théorie générale de la connaissance: Ses origines, ses lois, sa légitimité. Bio je član Belgijske kraljevske akademije, a od 1891. i njezin predsjednik.

14 Vidi o tome i Srećko Kovač, Formalizam i realizam u logici: Franjo pl. Marković i Gjuro Arnold, u časopisu Prilozi za istraživanje hrvatske filozofske baštine, god. 18., br. 35. - 36., 1992., str. 141-182. Usp. također Srećko Kovač, Logika u filozofiji Franje pl. Markovića, u spomenutome zborniku Filozofijsko djelo Franje pl. Markovića, str. 57-73. 
No koliko god da je Markoviću stalo do toga da pokaže »osnovanost« takva poimanja logike, možda još i više nastoji upozoriti na potpunu neutemeljnost Hegelova pristupa i uopće njegova shvaćanja logike, jer taj »najoštriji zastupnik njemačkoga idealisma (samopojamstva), ${ }_{1}^{15}$ pretvara znanost $\mathrm{u}$ puku umovinu ${ }^{16}$ (spekulaciju), veleći, da su pojmovi prava bića svieta (str. 88-89). S time se u vezi pozivlje i na jedan ulomak iz Compayréova predgovora francuskomu prijevodu Bainove Logike, pa kaže ovako (str. 84-85):

»Kako Compayré pobija čisto formalistično podpuno razstavljanje logike od psihologije i od stvarnih znanosti, tako on odsudjuje i podpuno spajanje logike s metafizikom, iliti, pravije rekavši, pretvaranje logike u metafiziku, koje hoće Hegel i njegova škola. Hegelova logika bavi se mišlju podpuno abstraktnom, posve odlučenom od zbiljnoga stvarstva, ${ }_{17}^{17}$ čistom idejom (pojmovinom $)^{18}$ t. j. najabstraktnijom čistom formom mislî; ali toj podaje Hegel takovu realnu stvornu snagu, da ona, t. j. čista pojmovina (ideja), čista abstraktna forma misli, svojim samosvojnim razvojem sve zbiljno stvarstvo, sve realne predmete upravo [\# tek] stvara.«

A evo što o Hegelovoj logici u navedenome predgovoru kaže sam Gabriel Compayré (navodim malo veći ulomak): ${ }^{19}$

»La logique, pour lui [= Hégel - B. M.], se confond avec la métaphysique. Elle est la science de l'idée en soi et pour soi. Elle doit être tout à fait séparée de la philosophie de la nature ou science de l'idée dans son existence concrète. Elle peut être délinie : la science de l'idée pure, de l'idée

15 Primijetiti je ovdje Markovićevu riječ samopojamstvo kao hrvatski prijevod za međunarodnu riječ idealizam (tj. idealisam, kako navodi Marković). Tako ima i samotvarstvo za materijalizam (tj. materialisam) i samoosjetstvo za senzualizam (tj. sensualisam). Te riječi ne donose ni Hrvatsko-njemačko-talijanski rječnik znanstvenoga nazivlja Bogoslava Šuleka (sv. I. - II., Tiskom Narodne tiskare dra. Ljudevita Gaja, Zagreb, 1874. - 1875.; pretisak: Globus, Zagreb, 1990.), ni Neues Wörterbuch der kroatischen und deutschen Sprache Ivana Filipovića (sv. 1. - 2., Verlag von Leop. Hartmán's Buchhandlung, Agram, 1875.), ni Vocabolario croato-italiano Dragutina Parčića, a nema ih ni Akademijin Rječnik hrvatskoga ili srpskoga jezika (sv. I. - XXIII., Jugoslavenska akademija znanosti i umjetnosti, Zagreb, 1880. - 1976.). I inače je dobro poznato da je Marković jedan od onih hrvatskih filozofa koji je osobitu skrb posvećivao nazivlju. O tome sam pisao na više mjesta, ali vidi primjerice Bojan Marotti, Nazivlje u Markovićevoj Etici, u časopisu Nova prisutnost, god. 16., br. 3., 2018., str. 487-507. Premda se u ovome radu ne raspravlja o logičkome nazivlju, upozoravam mjestimice na kakvu osobitu Markovićevu riječ.

Također Markovićeva riječ, koju uglavnom rabi kao prijevod za teorija, ali katkada i kao hrvatsku otpovjednicu za spekulacija. Ni ta se riječ ne nalazi u spomenutim rječnicima.

Ponovno jedna Markovićeva riječ, koja znači 'cjelokupnost (svih) stvari'. Ni tu riječ ne donose navedeni rječnici. Još jedna Markovićeva riječ, kao prijevod za ideja. Ni tu riječ nemaju navedeni rječnici.

19 Vidi Préface du traducteur, u knjizi: Alexander Bain, Logique: Déductive et inductive, traduit de l'anglais par Gabriel Compayré, str. XXX-XXXI. 
dans l'élément abstrait de la pensée. Au premier abord on se demande s'il n'y a pas là tout simplement une exagération emphatique, dissimulée par de grands mots, de cette vérité banale que la logique doit étudier uniquement les lois générales et communes à toute science. Mais, en y regardant de plus près, on s'assure vite qu'il n'y a aucun rapport entre les idées de Hégel et celles de la plupart des logiciens. Ce ne sont pas les lois fondamentales de la pensée, c'est la pensée pure, en dehors de ses déterminations empiriques, de ses applications à la réalité finie, c'est la pensée vide de tout contenu, ou n'ayant pour contenu que le monde supra-sensible, que Hégel veut étudier dans sa logique. Ce n'est pas ici le lieu d'examiner si dans de pareilles recherches Hégel aboutit à des résultats qui aient quelque solidité, ou à de pures chimères verbales.«

Premda se Marković dakle ne slaže s Hegelom, pa bi se za nj moglo reći ne samo to da nije hegelovac, nego štoviše da je i protuhegelovac, on ipak »osjeća potrebu za tim da ukratko prikaže Hegelovo stajalište, tj. taj njegov osobit pristup logici. No budući da u drugome dijelu, tj. u Sustavu logike, to više neće biti moguće, jer se Hegel, jednostavno rečeno, u takav sustavni prikaz logike ne uklapa, Marković u prvi, uvodni dio »dodaje«, ili »ubacuje« jedan poseban, posve zaokružen i u određenome smislu izdvojen odsjek, posvećen samo Hegelovoj logici, zapravo kritici Hegelove logike. Evo što o tome kaže sam Marković na kraju petoga odsjeka uvodnoga dijela (str. 93-94):

»Da je presezanje logike u zadatke metafizične po logiku samu štetno, to nam najjače pokazuje neuspjeh Hegelove absolutne logike, koja je najdotjeranija pretvorba logike u metafiziku. Zato ćemo u sliednjem odsjeku na kratko i jednostavno (po obsežnoj razpravi u Trendelenburgovu djelu Logička iztraživanja u I. svezku pag. 37-129) prikazati pogrešnost logike Hegelove, pošto je pogled na tu logiku samo na ovom razglednom mjestu uhoran, a poslije u samom sustavu logike ne bi tomu bilo više prilike.«

Taj je Markovićev postupak, sam po sebi, neobično važan, i to zato što ima logičara (i općenito filozofa) koji o Hegelovoj logici vrlo nerado govore. Primjerice, $u$ jednome od najpoznatijih priručnika iz povijesti logike, onome Williama i Marthe Kneale, pod naslovom The Development of Logic, a koji obaseže nešto manje od 800 stranica, ${ }^{20}$ Hegel se gotovo uopće ne spominje. ${ }^{21} \mathrm{~S}$ druge opet

$20 \quad$ Vidi William Kneale - Martha Kneale, The Development of Logic, At the Clarendon Press, Oxford, 1962. Navodim prema pretisku (s ispravcima) od godine 1971.

21 U Kazalu ga nema, ali se spominje primjerice u poglavlju From Saccheri to Hamilton (str. 345-358) tako reći usput, zajedno sa Schellingom (kojega također nema u Kazalu). Naime, potkraj se toga poglavlja, gdje je riječ o Kantu, kaže ovako (str. 358): »Already in 1844 the mathematician Gauss, writing to a 
strane, u svojevrsnome zborniku pod naslovom The Rise of Modern Logic: From Leibniz to Frege, 22 što je zapravo treći svezak uglednoga niza Handbook of the History of Logic, ${ }^{23}$ nalazimo poglavlje o Hegelu, koje je napisao John W. Burbidge. ${ }^{24}$ Na početku svoga priloga o Hegelovoj logici Burbidge kaže ovako:

"Although two of Hegel's works are called Logics, he is seldom considered a major figure in the history of logic. For the Science of Logic and the Encyclopedia Logic do not focus on the terms, propositions and syllogisms that make up the bulk of logic textbooks, but range through a number of concepts that sound more like traditional metaphysics, such as being, quality, quantity, essence, actuality, teleology and life. In addition, the discussion is cloaked in a dense and obscure language that appears to abandon the traditional conventions of argument that start from accepted premises and move on to justified conclusions."

Burbidge dakle misli da Hegelova logika »zvuči« u stvari »više kao tradicionalna metafizika", a to se slaže s onim što kaže i naš Marković, naime da je $u$ Hegela riječ o "pretvaranju logike u metafiziku«.

$\mathrm{U}$ »najavi« svoje kritike Hegela Marković izrijekom spominje poznato djelo Logische Untersuchungen Adolfa Trendelenburga (1802. - 1872.), ${ }^{25}$ na koje se ujedno u velikoj mjeri i oslanja. Trendelenburg je bio profesor filozofije u Berlinu, no bio je i klasični filolog. Bavio se je Platonom ( $\lambda \lambda \alpha ́ \tau \omega v)$ te osobito Aristotelom

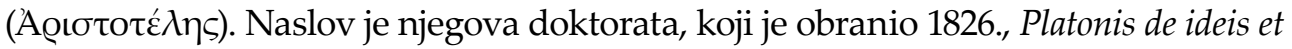
numeris doctrina ex Aristotele illustrata, ${ }^{26}$ a godine 1833. priredio je kritičko izdanje

friend about the absurdity of the pronouncements on mathematics by Schelling, Hegel, and a number of other philosophers, said [...].«

Vidi The Rise of Modern Logic: From Leibniz to Frege, edited by Dov M. Gabbay, Elsevier, North Holland, Amsterdam - Boston - Heidelberg - London - New York - Oxford - Paris - San Diego - San Francisco - Singapore - Sidney - Tokyo, 2004. Taj svezak ima 770 stranica.

Dosad je objelodanjeno 11 svezaka, približno istoga broja stranica. Posljednji je izašao 9. svezak, pod naslovom Computational Logic (edited by Jörg H. Siekmann), godine 2014.

Vidi John W. Burbidge, Hegel's Logic, u knjizi: The Rise of Modern Logic: From Leibniz to Frege, edited by Dov M. Gabbay, str. 131-175.

Marković se pri tome služi trećim izdanjem Trendelenburgovih Logičkih istraživanja, kojih je prvo izdanje objavljeno 1840. u dva sveska. Vidi Adolf Trendelenburg, Logische Untersuchungen, dritte vermehrte Auflage, Verlag von S. Hirzel, Leipzig, 1870. Posrijedi je poglavlje pod naslovom Die dialektische Methode u prvome svesku (str. 36-129). Vrijedno je pogledati i dvije rasprave koje je Trendelenburg objelodanio godine 1843. pod naslovom Die logische Frage in Hegels's System: Zwei Streitschriften (F. A. Brockhaus, Leipzig, 1843.), koje su prethodno izašle u časopisu Neue Jenaische allgemeine Literatur-Zeitung, prva u travnju 1842. (Zur Geschichte von Hegel's Logik und dialektischer Methode, br. 97., 98. i 99.), a druga u veljači 1843. (Die logische Frage in Hegels's System, br. 45., 46. i 47.)

Vidi Adolf Trendelenburg, Platonis de ideis et numeris doctrina ex Aristotele illustrata, Sumtibus Frid. Chr. Guil. Vogelii, Lipsiae, 1826. 
Aristotelova spisa $O$ duši (Пє@i $\psi v \chi \tilde{\eta} \varsigma)$. U Berlinu je Trendelenburgov slušač bio Franz Brentano (1838. - 1917.), koji mu je posvetio svoj znameniti doktorat pod naslovom Von der mannigfachen Bedeutung des Seienden nach Aristoteles, objelodanjen $1862 .{ }^{27}$ Kao što je poznato, ta je knjiga izvršila velik utjecaj na Martina Heideggera (1889. - 1976.). Brentano je godine 1874. postao profesorom filozofije $u$ Beču. ${ }^{28}$ Profesuru je preuzeo 22. travnja, a pet dana poslije, 27. travnja, car Franjo Josip I. imenovao je Franju pl. Markovića prvim »redovitim javnim profesorom za filozofiju teoretičku i praktičku i za poviest filozofije« na Mudroslovnome fakultetu Sveučilišta u Zagrebu. ${ }^{29} \mathrm{Na}$ jesen iste godine, u zimskome poljeću 1874./1875., Marković započinje s predavanjima, i to s uvodom u filozofiju (4 sata) i s predavanjima iz estetike (4 sata). ${ }^{30}$ Marković je pak doktorirao dvije godine prije, 8 . ožujka 1872., također u Beču, ${ }^{31}$ i to kod Roberta Zimmermanna (1824. - 1898.). Zimmermann je dakle bio Brentanov (stariji) »kolega« na Sveučilištu, a obojicu je, za vrijeme svoga studija filozofije u Beču (1884. - 1886.), slušao recimo jedan Edmund Husserl (1859. - 1938.). Husserla je dakako oduševio Brentano, koji ga je, među ostalim, upoznao s radovima Bernarda Bolzana (1781. - 1848.). No Bolzanov je slušač bio upravo Robert Zimmermann, taj Markovićev »učitelj«. Kažem »slušač«, premda to i nije posve dobra riječ. Valjalo bi naime reći da je pripadao »krugu oko Bolzana (Bolzanokreis). Pravi je Bolzanov učenik bio Zimmermannov otac, Johann August, profesor na gimnaziji i pjesnik, koji je postao doživotnim Bolzanovim prijateljem. No budući da je od siječnja godine 1820., odlukom samoga cara, Bolzanu bilo zabranjeno predavati, propovijedati i objavljivati, ${ }^{32}$ on je postao svojevrsnim duhovnim i intelektualnim mentorom mladoga Roberta. ${ }^{33}$

27 Vidi Franz Brentano, Von der mannigfachen Bedeutung des Seienden nach Aristoteles, Herder'sche Verlagshandlung, Freiburg im Breisgau, 1862. Vrijedno je navesti tu posvetu u cjelini (str. 3): »Meinem I verehrtesten Lehrer, I dem I um das Verständniß des Aristoteles I hochverdienten Forscher, I Dr. Adolph Trendelenburg, I ordentlichem Professor der Philosophie an der Berliner Universität, I in Ehrfurcht und Dankbarkeit I gewidmet.«

Iste je godine izašao prvi svezak njegova znamenitoga djela Psychologie vom empirischen Standpunkte (Verlag von Duncker \& Humblot, Leipzig, 1874.).

Vidi o tome potanje u spomenutoj knjizi Ivana Peklića Život i djelo Franje Markovića, str. 48.

Isto, str. 49

Isto, str. 23.

Otpušten je s Praškoga sveučilišta na sam Badnjak, 24. prosinca 1819., u 39. godini života.

Štoviše, oporukom mu je ostavio nedovršeni rukopis pod naslovom Grössenlehre (engleski Theory of Quantity), zamišljen kao filozofsko utemeljenje matematike, koji je međutim Robert Zimmermann držao kod sebe sve do 1882., kada ga je istom predao Austrijskoj akademiji znanosti (Österreichische Akademie der Wissenschaften), a ova ga, deset godina poslije, darovala Austrijskoj nacionalnoj knjižnici (Österreichische Nationalbibliothek). Pokazalo se je međutim, ali kakvih sedamdeset i pet godina nakon Bolzanove smrti, da je do nekih otkrića, primjerice u matematičkoj analizi, Bolzano došao znatno prije drugih matematičara, kojima su se inače ta otkrića pripisivala. (Ovaj dio bilješke 
To je dakle misaoni obzor, ili duhovni milieu, iz kojega dolazi i unutar kojega se kreće Franjo pl. Marković. Tu su još, dakako, i Johann Friedrich Herbart (1776. - 1841.), te donekle u pozadini Jakob Friedrich Fries (1773. - 1843.) i Friedrich Eduard Beneke (1798. - 1854.). ${ }^{34}$ A sve su to filozofi koji se u prvoj polovici devetnaestoga stoljeća, svatko od njih na svoj način, suprotstavljaju Hegelovu spekulativnomu idealizmu.

Što se pak Brentana tiče, njegov je utjecaj golem. ${ }^{35}$ Nije naime posve jednostavno ni nabrojiti komu je sve Brentano, posebice u Beču, bio profesorom. Stoga se često govori i o »Brentanovoj školi«(Brentanoschule). Još prije Beča, dok je predavao u Würzburgu, njegovi su slušači potkraj šezdesetih godina 19. stoljeća bili, primjerice, Carl Stumpf (1848. - 1936.) . $^{36}$ i Anton Marty (1847. - 1914.). ${ }^{37} \mathrm{~A}$ u Beču su mu bili slušači, osim već spomenutoga Edmunda Husserla, među ostalim, i Alexius Meinong (1853. - 1920.), Christian von Ehrenfels (1859. - 1932.), ${ }^{38}$ Kazimierz Twardowski (1866. -1938.), ${ }^{39}$ Sigmund Freud (1856. - 1939.), Tomáš Masaryk (1850. - 1937. $)^{40} \mathrm{i}$ - last but not least - Rudolf Steiner (1861. - 1925.). ${ }^{41}$ Taj bi

prenosim iz spomenutoga članka O Markovićevim filozofskim rukopisima u arhivima HAZU, str. 114, bilj. 14.) O odnosu Bolzana i Roberta Zimmermanna vidi Robert Zimmermanns philosophische Propädeutik und die Vorlagen aus der Wissenschaftslehre Bernard Bolzanos: Eine Dokumentation zur Geschichte des Denkens und der Erziehung in der Donaumonarchie, eingeleitet und herausgegeben von Eduard Winter, Verlag der Österreichischen Akademie der Wissenschaften, Wien, 1975., str. 14-16 (Winterov se Einleitung nalazi na str. 7-35). Usp. primjerice ovu rečenicu (str. 14): »R. Zimmermann hat seine Liebe zu Bolzano sozusagen mit der Muttermilch eingesogen.«

O tome potanje govorim u rečenome članku O Markovićevim filozofskim rukopisima u arhivima HAZU, str. 110-115 (poglavlje Je li Marković bio herbartovac?). Usp. i Vladimir Filipović, Franjo Marković - rodoljubni pjesnik i učitelj filozofije: Koliko u filozofiji Herbartovac?, u časopisu Prilozi za istraživanje hrvatske filozofske baštine, god. 8., br. 15. - 16., str. 7-24.

Općenito o tome vidi Barry Smith, Austrian Philososphy: The Legacy of Franz Brentano, Open Court Publishing Company, Chicago - LaSalle, Illinois, 1994.

Bio je, među ostalim, profesor u Berlinu, gdje ga je slušao i Robert Musil.

Marty je bio profesor na Praškome sveučilištu. Posebno se je bavio filozofijom jezika, filozofijom psihologije i ontologijom. Znatno je utjecao na Praški lingvistički krug. U Pragu ga je na sveučilištu slušao i Franz Kafka.

Bio je profesor u Pragu. Uveo je pojam Gestalta, čime je posredno utjecao na osnivanje i razvoj geštalt-psihologije.

Twardowski je doktorirao kod Roberta Zimmermanna. Bio je profesor u Lavovu. Smatra se utemeljiteljem Lavovske filozofsko-logičke škole (ili pak Lavovsko-varšavske logičke škole).

Naslov je njegove habilitacije (1879.) bio Der Selbstmord als sociale Massenerscheinung der modernen Civilisation.

41 Pojam antropozofije (tj. samu riječ) Steiner je preuzeo od Roberta Zimmermanna, iz njegove knjige objelodanjene 1882. pod naslovom Anthroposophie im Umriss: Entwurf eines Systems idealer Weltansicht auf realistischer Grundlage (Wilhelm Braumüller, Wien, 1882.). Usp. npr. sljedeću Zimmermannovu rečenicu iz njegova Predgovora (Vorrede, str. VII): »Anthroposophie ist der Name des Buches. Die Philosophie, welche denselben wählt, will damit angedeutet haben, dass es weder ihr Ziel sei, wie das der spekulativen Schule, Theosophie, noch ihr genüge, wie empirischer Unphilosophie, kritiklose Anthropologie zu sein.« 
se razvoj, kao i odnosi među filozofima koje spominjem, mogli ovako prikazati (punim su crtama naznačeni izravni utjecaji, a isprekidanima posredni):

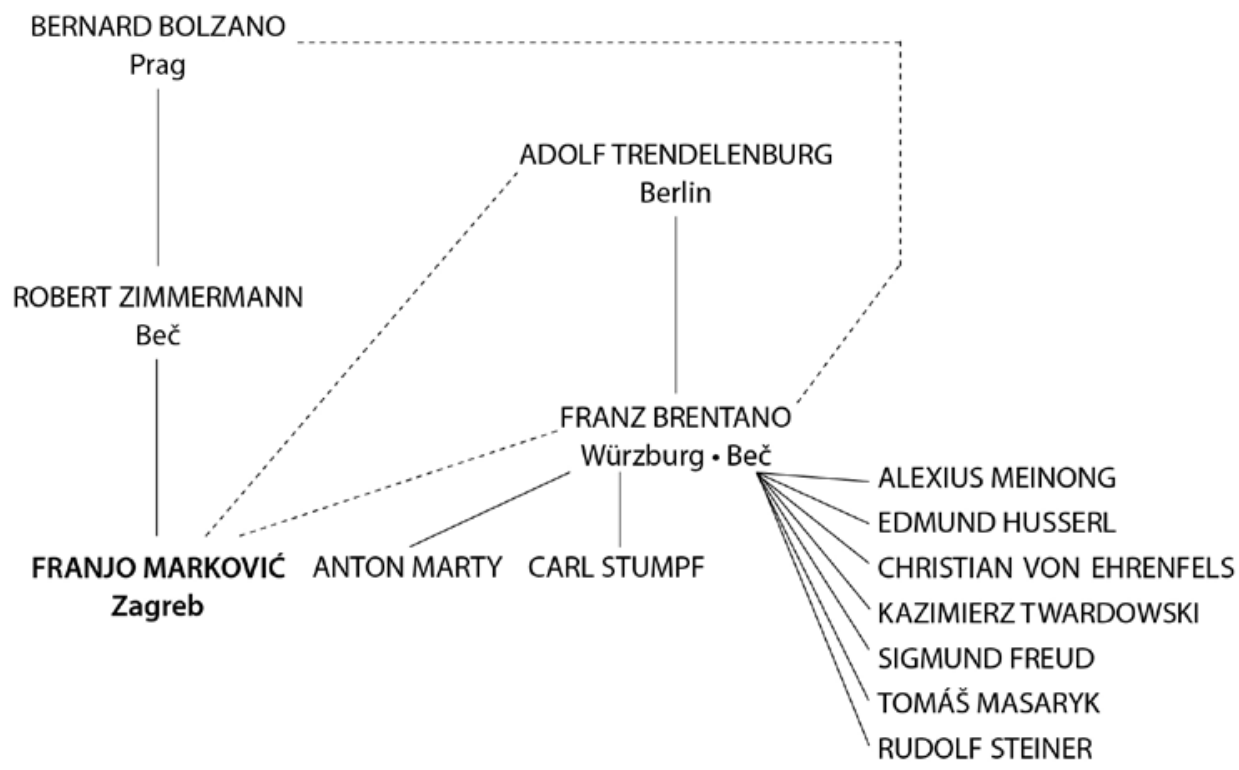

Marković je dakle, preko Zimmermanna, neizravno bio povezan i s Bolzanom, dok je, u drugu ruku, i sam Brentano bio u posrednoj vezi s Bolzanovom filozofijom. Stoga se može reći da u pozadini čitavoga toga razvoja, naime onoga što se katkada voli zvati »austrijskom filozofijom « (u razlici spram »filozofije $u$ Austriji $\ll$ ili »austrijskim realizmom « ${ }^{42}$ stoji zapravo Bernard Bolzano. A ovako o Bolzanu rasuđuje Jan Berg, jedan od urednika izdanja koje obuhvaća cjelokupno Bolzanovo djelo (Bernard-Bolzano-Gesamtausgabe): ${ }^{43}$

Vidi primjerice časopis The Monist, god. 83., br. 1. Taj je cijeli svezak navedenoga časopisa posvećen »austrijskoj filozofiji«, $\mathrm{i}$ to pod naslovom Austrian Realism: From Aristotelian Roots to the Vienna Circle.

43 Vidi Jan Berg, From Bolzano's Point of View, u časopisu The Monist, god. 83., br. 1., str. 47-67, navodak na str. 67. Usp. i moj spomenuti članak O Markovićevim filozofskim rukopisima u arhivima HAZU, str. 114, gdje također navodim Berga. U izdanju Bernard-Bolzano-Gesamtausgabe dosad je objelodanjeno 99 svezaka. 
»Bolzano is indubitably one of the greatest philosophers of the German language. His world view was a universal one in the sense that philosophy, mathematics, physics, and metaphysics should build upon the same logical foundations. In fact, he already recognized many of the essential things to come in logic and the foundations of mathematics. Hamlet's assessment would suit this truly universal mind accurately: "What a piece of work is a man! How noble in reason! How infinite in faculty!"«

$\mathrm{S}$ druge strane, uzme li se $\mathrm{u}$ obzir Trendelenburgov utjecaj na Brentana, valja uočiti i to da znatni poticaji za spomenutu struju, ili za takav pristup, a to $\mathrm{u}$ osnovi znači za protuhegelovstvo, dolaze ne samo s filozofske nego i s klasičnofilološke strane. To je posve shvatljivo, jer ako $u$ temelju, $u$ »korijenima«, toga »austrijskoga realizma« leži Aristotelova filozofija, tj. jedno osobito razumijevanje Aristotela, jasno je da je pretpostavka za takvo razumijevanje ponajprije temeljito čitanje Aristotelovih filozofskih djela. $S$ toga je stajališta također posve shvatljiva tvrdnja jednoga Michaela Dummetta kada primjerice kaže: ${ }^{44} »$ The term 'Anglo-American' is a misnomer that does a great deal of harm." Naime, nije posrijedi »anglo-američka tradicija«, nego je i ta struja zapravo »kontinentalna«. Jer, kako nastavlja Dummett: ${ }^{45}$

»Not only does it have the vicious effect of encouraging those who would accept the label for their work to believe that they have no need to read, let alone to write in, any language but English, but it gives a wholly false impression [istaknuo B. M.] of how analytical philosophy originated. [...] The sources of analytical philosophy were the writings of philosophers who wrote, principally or exclusively, in the German language [...].«

Napokon, Dummett ustvrđuje sljedeće: ${ }^{46}$ "What is more, they are the same roots [tj. »roots of analytical philosophy«- B. M.] as those of the phenomenological school, which appears to many the antithesis of analytical, or of what they think of as 'Anglo-American', philosophy.«

\section{Temeljno obilježje Hegelove filozofije}

No kako dakle izgleda ta Markovićeva kritika Hegelove logike? Ključno je pitanje pri tome, kao i općenito kada je riječ o kritici Hegela i njegove filozofije, odakle uopće samu kritiku započeti. Drugačije rečeno, s kojega je motrišta tu kritiku moguće poduzeti? Gdje pronaći uporište za jedan mogući kritički pristup?

\footnotetext{
Vidi Michael Dummett, Origins of Analytical Philosophy, Duckworth, London, 1993., str. ix (Preface).

45

Isto.

46 Isto.
} 
Da bi došao do takva uporišta, ili da bi ga na neki način uspostavio, Marković u prvome odjeljku šestoga odsjeka uvodnoga dijela Logike prije svega nastoji uklopiti Hegelov pristup logici, a bolje bi bilo reći - Hegelovu filozofiju u cjelini, upravo Hegelovo poimanje svega što jest, $u$ jedan širi okvir, naime $u$ obzor povijesti filozofije. Stoga podastire jedan vrlo sažeti prikaz onoga pravca u povijesti filozofije kojemu, po njegovu mišljenju, pripada i sam Hegel. To ga

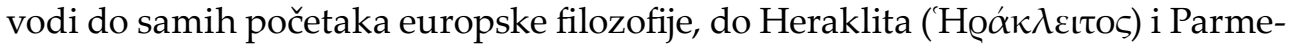
nida (П $\alpha \varrho \mu \varepsilon v i \delta \eta \varsigma) .{ }^{47}$ Pošto je ukratko naznačio njihove osnovne tvrdnje, prelazi zatim na Platona, za kojega kaže da »je postavio nauku, koja nadovezuje na one dvie medjusobom suprotne« (str. 94). Platon zapravo, po Markovićevu mišljenju, nastoji »pomiriti«, ili »premostiti« te dvije suprotstavljene filozofije, naime s jedne strane Heraklitovu, »da je vječita neprestana promjena jedino stalno i bićno (substancijalno) u svietu « (str. 94), te s druge strane Parmenidovu, »da je jedno jedino, vječito, nepromjenljivo, beztvarno biće, koje ima sámo pravi bitak, a da su sve pojedinačne tvarne promjenjive stvari puki prolazni prividi bez bitka« (str. 94). Tako Platon smatra, veli Marković, da ono što ima nepromjenljiv bitak, što je doista biće ili »nješto«, ne može biti tvarno, jer sve što je tvarno, neprestano se mijenja. No »iznad« tvari opstoje netvarne ideje (Marković kaže »beztvarne«), i one su prava bića, jer su nepromjenljive i vječne. Utoliko svaki naš pojam, npr. pojam stola, ima svoj "pralik« u ideji, ali pri tome taj pralik nije puka misao, bilo ljudskoga bilo božanskoga duha, nego je samostalno biće, koje »obstoji kao biće od vieka do vieka u nadnebesju« (str. 95). Tako primjerice jedan određeni stol nosi na sebi »palik«ideje i samo zato ima bitak, naime zato što je palik svoga (idealnoga) pralika. Cjelina pak svih takvih pralikova, tj. ideja, zapravo je cjelokupno tò óv, ili, kako kaže Marković, bićje, a tvar nije drugo negoli tò $\mu \eta \eta$ óv, naime nebićje. Naš je pak pojavni svijet "spojevina idejâ i tvari, bićja i nebićja» (str. 96).

Platon je dakle, nastavlja dalje Marković, naše pojmove »obićio«, tj. uzdigao ih

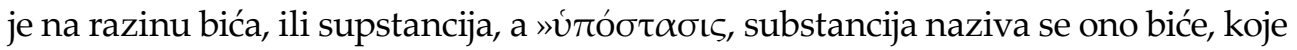
stoji i obastaje vječito pod pojavnom prolaznom tvari« (str. 96). Time pak što ih je obićio, pojmovi su postali »pojmovine«. I valja odmah dodati da je to, ta "pretvorba« pojmova u »pojmovine«, nešto s čime se Marković ne slaže. Istina, to na ovome mjestu još ne kaže izrijekom, ali daljnji će izvod pokazati da jest tako.

Potom Marković prelazi na srednjovjekovnu filozofiju, i to na skolastiku. Pri tome razmatra dvije oštro suprotstavljene struje: nominalizam i realizam. Pristaše nominalizma smatraju, veli Marković, da samo pojedine stvari imaju bitak, tj. da ono što je pojedinačno, doista jest, a da pojmovi nisu bića, nego da su samo naše misli, koje su izražene riječima, tj. da su pojmovi upravo puke riječi. Prista-

Govori zapravo o »Elejskoj školi« (str. 94). 
še pak realizma tvrde obrnuto, naime da pojmovi nisu puke misli (a još manje puke riječi), nego da su bića, tj. res ('stvari').

Valja uočiti da Marković, u vezi s tzv. srednjovjekovnim "problemom univerzalija«, navodi isključivo dvije skrajnosti: (dosljedni) nominalizam i (pretjerani) realizam (latinski realismus exaggeratus, tj. »exaggerated realism«, ili »ultra-realism«, kako ga zove Frederick Copleston). ${ }^{48}$ No njihove umjerene inačice (na ovome mjestu) ne spominje, naime tzv. konceptualizam i umjereni realizam (»moderate realism", kako veli Copleston). ${ }^{49}$ Dakako, nominalizmu i konceptualizmu zajedničko je izrazito proturealističko stajalište, no umjereni se realizam i sam javlja u više inačica. $\mathrm{Na}$ taj se način, budući da je protivnik (pretjeranoga) realizma, stječe dojam kao da bi Marković bio blizak nominalizmu. To međutim ne stoji. Što se tiče spomenutoga "problema univerzalija«, moglo bi se ustvrditi da je vjerojatno najbliži bio konceptualizmu jednoga Pierrea Abélarda (koliko god da je imao određene primjedbe i na konceptualizam, kako se vidi iz sedmoga odsjeka uvodnoga dijela Logike). ${ }^{50} \mathrm{No}$ ovdje mu je očevidno stalo do toga da što je moguće više zaoštri navedenu suprotnost, kako bi nakon razmatranja nominalizma i realizma mogao iznijeti svoj glavni stavak (str. 97): »Na Platonovu nauku, da su ideje ili pojmovine t. j. obićeni pojmovi prava bića, i na sholastičnu realističnu nauku, da su sami pojmovi prave stvarevine, res t. j. bića, nadovezuje Hegelova nauka absolutne logike.«

Prema tome, taj pravac u povijesti filozofije kojemu pripada Hegel, tj. u koji se Hegel može uvrstiti, izgleda ovako: Platon (i novoplatonizam) - srednjovjekovni realizam - Hegel. Jer, kako kaže Marković, za Hegela čisti pojam neke stvari, »to

$\overline{48}$ Vidi Frederick Copleston, A History of Philosophy, sv. II. Medieval Philosophy, Image Books - Doubleday, New York - London - Toronto - Sydney - Auckland, 1993., str. 140, te npr. str. 141. No vidi i čitavo poglavlje pod naslovom The Problem of Universals (str. 136-155). Usp. također Friedrich Ueberweg, Die patristische und scholastische Philosophie, herausgegeben von Dr. Bernhard Geyer, 12. Auflage, unveränderter Nachdruck der völlig neubearbeiteten 11. Auflage, Akademische Drucku. Verlagsanstalt, Graz, 1951., str. 205-213 [poglavlje Die Universalienfrage (Nominalismus und Realismus)]. Posrijedi je dakle 11. izdanje znamenite Ueberwegove Povijesti filozofije (Friedrich Ueberwegs Grundriss der Geschichte der Philosophie), koje je uredio Bernhard Geyer, pa se često navodi kao »Ueberweg-Geyer«. Taj je dio izvorno objelodanjen 1928., tj. prije kakvih devedesetak godina, međutim to je do danas posljednja preradba toga drugoga sveska.

Vidi Frederick Copleston, A History of Philosophy, sv. II. Medieval Philosophy, npr. str. 151. U vezi s time zanimljiva je nevelika knjiga Meyricka H. Carréa pod naslovom Realists and Nominalists (Oxford University Press, Oxford, 1946.), koja se sastoji od ovih četiriju poglavlja: Saint Augustine, Peter Abaelard, Saint Thomas Aquinas i William of Ockham. Ta poglavlja odgovaraju pak četirima spomenutim (temeljnim) gledištima na "problem univerzalija«.

Vidi o tome Bojan Marotti, O pojmu znaka u Markovićevoj Logici, u spomenutome zborniku Filozofijsko djelo Franje pl. Markovića, priredio Stipe Kutleša, str. 75-139. O Abélardovu pristupu vidi Bojan Marotti, Kako oriječiti misao?: O jednome Krstićevu prigovoru Šančevoj Filozofiji srednjega vieka, u časopisu Scopus, god. 4., br. 13. - 14., 2000., str. 33-44, posebice str. 39-40. Usp. također Bojan Marotti, Pojam jezika u Kruna Krstića (članci 1940. - 1945.), u časopisu Prolegomena, god. 4., br. 1., 2005., str. 71-92. 
jest pojam njezin odlučen od svih osjetivih oznakâ njezinih« (str. 97), nije samo bivstvo (tj. sama sućina) nego i bitak te stvari. To opet znači da čista misao o stvari, »odlučena (abstraktna) od svih osjetnih pomišljaja stvari, nije od stvarî odvojena nego je istovjetna sa stvarju « (str. 97). Hegel dakle također »obićava« pojmove, čini ih bićima, onime što doista jest. I to je zapravo temeljno obilježje Hegelove filozofije. A na osnovi takva shvaćanja istom je moguće, ako "počnemo s najodlučenijim (najabstraktnijim) pojmom« (str. 97), razviti iz njega neprekinuti niz pojmova, »koji će u svojoj cjelokupnosti i u svom razvoju biti istovjetni s cjelokupnošću pravih bića i pravoga bitka ter razvitka svega svieta« (str. 98). Marković napokon zaključuje ovako (str. 98):

\begin{abstract}
»Osnovna načelna tvrdnja te logike jest: najodlučeniji (najabstraktniji) pojam, kao početak svih ostalih pojmova, razvija sam iz sebe, bez ikakve pomoći opažajnih, osjećanjem stvarnim nastalih pomisli, sveukupnost pojmova, dakle sveukupnost bića svega svieta.«
\end{abstract}

A upravo se s time Marković ne slaže. Naime to je isto ono, rečeno na drugačiji način, što je već bio ustvrdio krajem petoga odsjeka, tj. da je Hegelova logika »najdotjeranija pretvorba logike u metafiziku«. Istina, treba primijetiti da je Hegel toga posve svjestan. Tako, primjerice, u Uvodu (Einleitung) u Znanost logike (Wissenschaft der Logik), u dijelu pod naslovom Opća razdioba logike (Allgemeine Einteilung der Logik) kaže ovako: ${ }^{51}$ »Die objektive Logik tritt damit vielmehr an die Stelle der vormaligen Metaphysik, als welche das wissenschaftliche Gebäude über die Welt war, das nur durch Gedanken aufgeführt sein sollte.« Poznato je naime da Hegel logiku dijeli na dva dijela: na objektivnu i na subjektivnu (tj. nauk o pojmu), a objektivnu potom također na dva dijela, tj. na nauk o bitku i na nauk o biti, pa se može govoriti i o trodijelnoj razdiobi njegove logike (i ujedno Znanosti logike). Ili pak, kako to sam kaže na kraju Uvoda: ${ }^{2}$

51 Sva Hegelova djela navodim prema izdanju Georg Wilhelm Friedrich Hegel, Werke in zwanzig Bänden, Suhrkamp Verlag, Frankfurt am Main. U tome je izdanju Znanost logike objavljena u dva sveska (Wissenschaft der Logik I i Wissenschaft der Logik II) godine 1969., i to: sv. 5. Erster Teil: Die objektive Logik: Erstes Buch, te sv. 6. Erster Teil: Die objektive Logik: Zweites Buch; Zweiter Teil: Die subjektive Logik. Gornji se navodak nalazi u Wissenschaft der Logik I, str. 61. Hrvatski je prijevod Hegelove Znanosti logike objelodanjen u tri sveska (Demetra, Zagreb, 2003.), i to: sv. 1. Prvi dio: Objektivna logika. Prvi svezak: Nauk o bitku (1832), preveo Sulejman Bosto, redaktura Željko Pavić i Dimitrije Savić, sv. 2. Prvi svezak: Objektivna logika. Knjiga druga: Nauk o bîti (1813), preveo Željko Pavić, te sv. 3. Drugi svezak: Subjektiona logika ili Nauk o pojmu (1816), preveo Željko Pavić. Navedeno mjesto Sulejman Bosto prevodi ovako (sv. 1., str. 48): „Time objektivna logika štoviše stupa na mjesto negdašnje metafizike, kakvo bijaše znanstveno zdanje o svijetu koje je trebalo biti izvedeno samo mislima.«

Vidi Georg Wilhelm Friedrich Hegel, Wissenschaft der Logik I, str. 62. Usp. i hrvatski prijevod (Znanost logike, sv. 1., str. 49): »Logika se, dakle, uopće dijeli na objektivnu i subjektionu logiku, ali, određenije, ona ima tri dijela: | I. Logiku bitka | II. logiku bîti i I III. logiku pojma.« 
»Die Logik zerfällt also zwar überhaupt in objektive und subjektive Logik; bestimmter aber hat sie die drei Teile:

I. Die Logik des Seins,

II. die Logik des Wesens und

III. die Logik des Begriffs.»

Ta je trodijelnost možda vidljivija u Enciklopediji filozofskih znanosti (Enzyklopädie der philosophischen Wissenschaften), gdje se kaže ovako: ${ }^{.3}$

»Die Logik zerfällt in drei Teile:

I. Die Lehre von dem Sein,

II. Die Lehre von dem Wesen,

III. Die Lehre von dem Begriffe und der Idee."

Marković međutim strogo luči logiku i metafiziku. On želi povući čvrstu granicu između onoga što se u mišljenju (sämo) misli (a ne mora uistinu i biti) i onoga što doista jest. Stalo mu je naime do toga da se jasno razlikuje mišljevina bilo pomisao, bilo predodžba i sl. - od (pojedinačnoga) bića. Recimo onako kako to sažeto kaže Beneke: ${ }^{54}$

»Die Grundaufgabe der Metaphysik ist: “das Verhältniß unseres Vorstellens zu Sein" zu bestimmen, und die so ganz entgegengesetzten Behauptungen, welche man als Lösung dieser Aufgabe hingestellt, haben in Vielen die Meinung erzeugt, als sei dieselbe für unser Erkennen überhaupt nicht möglich. Diese Meinung muß durch die gegebene Auseinanderseztung für jedes klare Denken widerlegt werden.«

$\overline{53}$ U navedenome je izdanju Enciklopedija [Enzyklopädie der philosophischen Wissenschaften im Grundrisse (1830)] objavljena u tri sveska godine 1970., i to: sv. 8. Erster Teil: Die Wissenschaft der Logik: Mit den mündlichen Zusätzen, sv. 9. Zweiter Teil: Die Naturphilosophie: Mit den mündlichen Zusätzen, te sv. 10. Dritter Teil: Die Philosophie des Geistes: Mit den mündlichen Zusätzen. Gornji se navodak nalazi u prvome od triju svezaka, tj. u Die Wissenschaft der Logik, str. 179. Usp. i hrvatski prijevod, koji je objelodanjen u jednome svesku (Enciklopedija filozofijskih znanosti, preveo Viktor D. Sonnenfeld, 2. izdanje, »Veselin Masleša - Svjetlost, Sarajevo, 1987., str. 102): »Logika se dijeli na tri dijela: I I. na nauku o bitku, I II. nauku o biti, I III. nauku o pojmu i ideji.« Die Wissenschaft der Logik, koja je jedan od triju dijelova Hegelove Enciklopedije, često zovu i »malom« Logikom (u razlici spram »velike« Logike, tj. spram Wissenschaft der Logik).

54 Vidi Friedrich Eduard Beneke, Neue Grundlegung zur Metaphysik, In Commission bei E. S. Rittler, Berlin - Posen, 1822., str. 8. Posrijedi je nevelika rasprava, koja je trebala biti nekom vrstom nacrta, ili »programa«, za njegova predavanja kada je postao Privatdozent. Usp. i moj članak O Markovićevim filozofskim rukopisima u arhivima HAZU, str. 113, gdje također navodim Benekea. 
I zatim malo dalje: ${ }^{5}$

»Wir können den vollen Idealismus am besten auf seinem eigenen Standpunkte fassen. Wir geben ihm scheinbar zu, was er behauptet, daß wir nämlich nur Vorstellungen haben (keine Vergleichung derselben mit ihrem Sein).«

Na taj je način Marković sebi otvorio prostor, tj. pronašao »mjesto u sustavu«, te time zadobio uporište odakle može započeti pravu kritiku Hegelove logike. Ta se kritika svodi na dva osnovna prigovora:

- Nije moguće iz jednoga (najapstraktnijega, tj. »najodlučenijega«) pojma, koji bi bio početak svih ostalih pojmova, razviti sveukupnost pojmova (te ujedno sveukupnost cjeline svega što jest) bez pomoći opažajnih pomisli.

- Postupak apsolutne logike sam je u sebi »nelogičan«, tj. protivan neoborivim zakonima logike.

Marković se pri tome ponajviše zadržava na Hegelovoj objektivnoj logici, što je i razumljivo, jer upravo se tu najjasnije očituje ta "pretvorba logike u metafiziku«. Evo kako izgledaju ta dva prigovora.

\section{4. »Podmetanje« osjetnoga opažanja}

Svoju kritiku Marković započinje raščlambom posve jednostavnih, tzv. egzistencijalnih sudova, poput »Bog jest«, »čovjek jest«. Ti, kako ih Marković zove, »existencijni ${ }^{56}$ sudovi« tvrde samo bitak subjekta, ili bitak podmeta. Od njih bi još bili jednostavniji jedino tzv. »bezsubjektni sudovi« (ili »bezsubjektne izreke«), poput »grmi «, koji tvrde samo bitak osjeta, tj. samo »osjećanje grmljavine«. No ako se $\mathrm{u}$ »existencijskim« sudovima uklone svi subjekti, ostane samo predikat, ili prirok »jest«, koji dakle tvrdi bitak. I to je taj najjednostavniji pojam, naime pojam bitka, jer ako bismo uklonili i taj pojam, ne bi više bilo ničega. To je razlog, prema Markovićevu mišljenju, što Hegel započinje u Znanosti logike od toga pojma, tj. od pojma bitka, koji, pošto je apstrahiran (»odlučen«) od svih subjekata, jest zapravo sam čisti bitak (dakle ne sämo pojam bitka, nego sámo bïti).

Međutim, budući da su od toga pojma čistoga bitka (i ujedno od bitka samoga) uklonjeni svi subjekti, što znači da su svi oni zanijekani, taj je pojam čistoga bit-

\footnotetext{
Vidi Friedrich Eduard Beneke, Neue Grundlegung zur Metaphysik, str. 9.
}

56 Uočiti je odnosni pridjev existencijni, a ne egzistencijalni, ni egzistencijski (u Markovićevu bi zapisu bilo

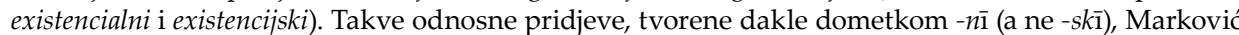
često rabi, poput apercepcijni, bezreflexijni, funkcijni, interferencijni, kategorijni, substancijni i sl. O porabi takvih pridjeva vidi Bojan Marotti, Rječnik hrvatskoga filozofskoga nazivlja, u časopisu Prilozi za istraživanje hrvatske filozofske baštine, god. 35., br. 69. - 70., 2009., str. 123-180, posebice str. 139-140, te str. 156-158 
ka istodobno i čisti (ili najpotpuniji) nijek, dakle čisto ništo (Marković kaže upravo tako: ništo, tj. »ni što«, naime »ni jedno jedino što«, jer je svaki subjekt zanijekan). I na tome mjestu Marković navodi znameniti stavak iz Hegelove Znanosti logike, naime »"das reine Sein und das reine Nichts ist dasselbe"« (str. 100). ${ }^{57}$ Bitno je pri tome uočiti, želimo li razumjeti Hegelovo shvaćanje logike, da taj prvi, početni pojam sam iz sebe razvija, tako reći, "zahtijeva« taj drugi pojam. I budući da su ta dva pojma, smatra Marković, po svome »bivstvu« (ili po svojoj sućini) »istovjetna«, oni se, veli dalje Marković, »ujedine « u novi, treći pojam, naime u pojam bivanja, ili pojam postajanja (das Werden). Hoteći to pobliže objasniti, Marković kaže da "postajanje sastavlja i ujedinjuje s nebitkom bitak (str. 100), te u vezi s time podastire i jedan primjer (str. 100): »[...] dok biva (postaje) dan, on još nije, a i jest već; postajanje njegovo je postupno prelaženje iz nebitka u bitak, iliti spajanje nebitka s bitkom.«

Valja međutim primijetiti da to nije u potpunosti ono što tvrdi Hegel. Nije naime dobro reći da su ta dva pojma po svome bivstvu istovjetna (tj. da se ne razlikuju, da nisu »razlikovana«, kako bi rekao Hegel). Prije bi se moglo ustvrditi da je posrijedi istovjetnost istovjetnosti i razlike (identitet identiteta i diferencije), te da zbog toga ta dva pojma, sama iz sebe, razvijaju (ili opet - »zahtijevaju«) taj treći pojam. Zapravo, sama istovjetnost (te istovjetnosti i razlike) tako »zahtijeva«, a ta istovjetnost (te istovjetnosti i razlike) i nije drugo nego pojam bivanja (i ujedno bivanje samo). Evo kako to kaže Hegel: ${ }^{58}$

"Was die Wahrheit ist, ist weder das Sein noch das Nichts, sondern daß das Sein in Nichts und das Nichts in Sein - nicht übergeht, sondern übergegangen ist. Aber ebensosehr ist die Wahrheit nicht ihre Ununterschiedenheit, sondern daß sie nicht dasselbe, daß sie absolut unterschieden, aber ebenso ungetrennt und untrennbar sind und unmittelbar jedes in seinem Gegenteil verschwindet. Ihre Wahrheit ist also diese Bewegung des unmittelbaren Verschwindens des einen in dem anderen: das Werden; eine Bewegung, worin beide unterschieden sind, aber durch einen Unterschied, der sich ebenso unmittelbar aufgelöst hat.«

57 Rečenica zapravo glasi ovako: »Das reine Sein und das reine Nichts ist also dasselbe « Vidi Georg Wilhelm Friedrich Hegel, Wissenschaft der Logik I, str. 83. Usp. i hrvatski prijevod (Znanost logike, sv. 1., str. 72): "Čisti bitak i čisto Ništa jest dakle isto.«

Isto. U hrvatskome je prijevodu ovako (isto): „To što je istina nije ni bitak ni Ništa, nego da bitak - ne: prelazi - nego da je prešao u Ništa a Ništa [prešlo] u bitak. Ali jednako toliko istina nije njihova razlikovanost [tj. nerazlikovanost, naime Ununterschiedenheit - B. M.] nego da oni nisu isto, da su apsolutno različiti, ali jednako tako jesu nerazdvojeno i nerazdvojivo i neposredno svako iščezava $u$ svojoj suprotnosti. Njihova je istina, dakle, kretanje neposrednoga iščezavanja jednoga u drugomu: postajanje, jedno kretanje, u kojem su oboje razlikovani, ali kroz jednu razliku koja se jednako tako neposredno ukinula.« 
Prema tome, ta su dva pojma, bitak i ništo, posve razlikovana (»absolut unterschieden«), ili bezuvjetno razlikovana, ili u potpunosti razlikovana (drugačije rečeno: posve se razlikuju, bezuvjetno se razlikuju, u potpunosti se razlikuju), jer nije istina njihova nerazlikovanost (»ihre Ununterschiedenheit«), nego je istina neposredno iščezavanje, ili nestajanje razlikovanosti, tj. (jedne) istovjetnosti i (jedne) razlike $\mathrm{u}$ istovjetnosti koja se zove bivanje.

Pošto je razmotrio prva tri pojma, ili, kako kaže, "prvu trojnu skupinu«, tj. »1. čisti bitak, 2. čisti nebitak, 3. postajanje« (str. 100), Marković upozorava na Hegelovu vezu s Platonom. Naime, čistomu bitku odgovaraju u Platona ideje,

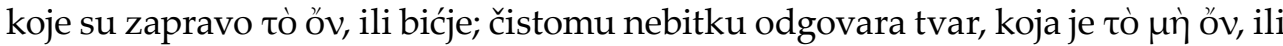
nebićje; a »sastavak idejâ i tvari, bićja i nebićja je tò $\gamma$ $\gamma$ vó $\mu \varepsilon v o v$, ono, što postaje, a to je sve pojavno stvarstvo « (str. 100). Ta se povezanost i određena usporednost može ovako prikazati u preglednici:

\begin{tabular}{|c|c|}
\hline HEGEL & PLATON \\
\hline čisti bitak & 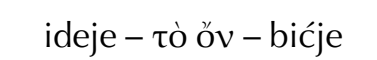 \\
\hline čisti nebitak & 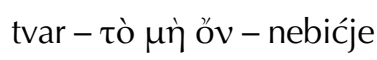 \\
\hline postajanje (bivanje) & 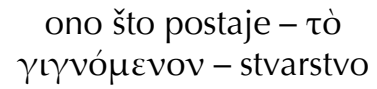 \\
\hline
\end{tabular}

Markoviću je u toj »trojnoj skupini« ponajviše prijeporan treći pojam, tj. postajanje ili bivanje, i to zato što smatra da taj treći pojam, iz onih prvih dvaju, nije moguće izvesti čistim mišljenjem, a bez pomoći osjetnoga opažanja. Drugim riječima, ne stoji da pojam bivanja (i dosljedno, bivanje samo) "proistječe« iz pojma čistoga bitka i iz pojma čistoga nebitka. To bi značilo da je posrijedi određena Hegelova "proizvoljnost«, ako ne i neka vrsta "prikrivanja«. Marković to izriče ovako (str. 101): »Pojam postajanja doznan (dobiven) je osjetnim opažanjem zbiljnih promjenljivih pojavnih stvari, pak je odatle kriomce primetnut čistomu bitku i nebitku, a nije domišljen samim čistim mišljenjem.« Štoviše, riječ je zapravo o »podmetanju«.

Dakle već je kod prve »trojke « prijeporan treći pojam, i to zato što je čisto mišljenje nemoćno: ono samo, bez pomoći iskustva, tj. opažanja, ne može dospjeti do toga trećega pojma. No to se, smatra Marković, ponavlja i dalje, »diljem svega razvoja pojmovâ absolutne logike« (str. 102), jer je takav Hegelov »metodni postup«, 
naime ovakav tročlani: »najprije tvrdnja (pozicija), onda nijek njezin (negacija), zatim, radi nutarnje istote nijeka s tvrdnjom, sastav (sinteza) obojega u treći pojam ječan« (str. 103).

Uočiti je ovdje pridjev ječan, koji Marković rabi u značenju 'potvrdan', 'jestan', 'afirmativan'. To je naime jedna od ključnih riječi u Markovićevoj Logici. Taj pridjev, kao i imenicu jek, glagol jekati i glagolnu imenicu jekanje nalazimo u Šulekovu $\mathrm{Hr}$ vatsko-njemačko-talijanskome rječniku znanstvenoga nazivlja (kojemu je dakle prvi svezak objavljen godinu dana prije negoli je Marković započeo predavati logiku, tj. 1874.). Šulek ima ovako: $5^{59}$

- Ječan, phil. affirmativ, bejahend, lat. affirmativus; ječna izreka, Behauptungssatz; $v$. Affirmativus; ${ }^{60}$ Aussagesatz, tal. proposizione affermativa.

- Jek, phil. lat. positio, Satz, (opp. negatio).

- Jekanje, phil. gr. ${ }^{61}$ lat. affirmatio, Affirmation, Bejahung, tal. affermazione.

- Jekati, gr. lat. affirmare, affirmiren, bejahen, tal. affermare, dir di si.

Filipović ima ječan, jekanje i jekati, a jek nema u navedenome značenju, dočim Parčić ima ječan, jek i jekati, a nema glagolnu imenicu jekanje. ${ }^{62}$ Akademijin rječnik navodi međutim sve četiri riječi. ${ }^{63}$ Taj je svezak obrađivao Petar Budmani. Pri tome je obilježio i naglasak, osim na pridjevu ječan. Tako ima jêk (genitiv bi bio jêka), jékâné (tj. jékāné) i jékati, jêčêm (tj. jêčēm). Za pridjev veli »kojijem se kaže da što jest, suprotno:

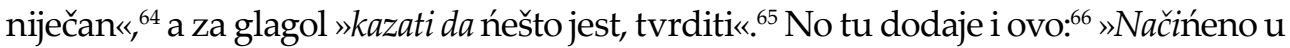
naše vrijeme kao protivno nijekati (uprav govoriti nije); ali treba promisliti da nije jednako dobra riječ kao i ova, jer se doista kaže nije kad se što poriče, ali kad se što tordi ne kaže se jë nego jest (ovako je kod onoga dijela našega naroda na čijemu je govoru osnovan kńiževni jezik, vidi dalı kod jesam).« I zatim se pozivlje na spomenuti Šulekov rječnik.

59 Vidi Bogoslav Šulek, Hrvatsko-njemačko-talijanski rječnik znanstvenoga nazivlja, sv. I., (redom) str. 453, str. 457.

No tu Šulek navodi i ječan i jestan (str. 19).

61 Kratica gr. znači 'grammatica' (str. XXIX), tj. 'gramatički', 'koji se tiče gramatike'.

62 Vidi Ivan Filipović, Neues Wörterbuch der kroatischen und deutschen Sprache, II. Kroatisch-deutscher Theil, sv. 1., (redom) str. 397-398, str. 407; Dragutin Parčić, Vocabolario croato-italiano, (redom) str. 302, str. 307.

63 Vidi Rječnik hrvatskoga ili srpskoga jezika, sv. IV., 1892. - 1897., (redom) str. 505, str. 571-572. Dotični je "sveščić« izašao upravo 1895.

Isto, str. 505.

65 Isto, str. 571.

66 Isto. 
Poznati bi dakle Hegelov tročlani niz u dijalektici, naime teza (afirmacija) antiteza (negacija afirmacije) - sinteza (negacija negacije), prema Markoviću glasio: jek - nijek - sastav (koji je ponovni jek). ${ }^{67}$ Štoviše, Marković podastire i jedan shematični prikaz toga Hegelova »metodnoga postupa ${ }^{68}$ a moguću primjedbu da oslikava, da upravo »crta« nešto što inače pripada čistomu mišljenju, otklanja pozivljući se pri tome na Eduarda Zellera (1814. - 1908.) i na njegovu knjigu Geschichte der deutschen Philosophie seit Leibniz, objelodanjenu 1873. (tj. dvije godine prije negoli je Marković započeo s predavanjima iz logike). ${ }^{69}$ Budući da sam crtež nalikuje na kostur (njemački das Gerippe), Marković veli da i Zeller tvrdi da je logika »"po Hegelu okostnica, kostur svieta"« (str. 103). No evo što kaže sam Zeller: ${ }^{70}$

»Er verlangt daher, daß die Logik mit der Metaphysik, oder genauer: mit dem ontologischen Theile der Metaphysik [...] zusammenfalle, und ebendadurch soll sich seine Logik als spekulative von der gewöhnlichen, blos formalen, unterscheiden. Sie soll, wie er sagt, das System der reinen Vernunft, das Reich des reinen Gedankens sein. Sie soll die Wahrheit darstellen, wie sie ohne Hülle an und für sich selbst ist, den ganzen Organismus der Denkbestimmungen, welche, so zu sagen, den innern Kern, das logische Gerippe der Welt bilden [istaknuo B. M.]; oder wie dieß populärer ausgedrückt wird: sie soll die darstellung Gottes sein, wie er in seinem ewigen Wesen vor der Erschaffung der Natur und eines endlichen Geistes ist.«

Pošto je pokazao prijepornost trećega pojma, Marković svoj dokazni postupak, moglo bi se reći, okreće unatrag. Naime ne samo da je treći pojam dobiven uz pomoć iskustva, tj. na osnovi zbiljnoga opažanja, nego je i drugi, tj. nijek, dobiven na isti način, a jednako tako i sam prvi pojam, tj. onaj ječni. Stoga Marković zaključuje ovako (str. 105):

\footnotetext{
67 Govoreći u svojoj Estetici o Hegelovoj »metodi trostupnjevnoga razvoja« Marković kaže ovako: »Tu metodu, koja prikazuje razvoj absolutnoga svebićja tezom, antitezom i sintezom (riekom, porjekom i sriekom), preuzima Hegel od Fichtea [...].« Tu bismo dakle imali: riek - porjeka - sriek. Vidi Franjo Marković, Razvoj i sustav obćenite estetike, Nakladom kr. hrv.-slav.-dalm. zemaljske vlade, Zagreb, 1903., str. 184 (pretisak: Izdavačka radna organizacija LOGOS, Split, 1981.).

68 Vidi taj prikaz u Dodatku.

69 Vidi Eduard Zeller, Geschichte der deutschen Philosophie seit Leibniz, R. Oldenbourg, München, 1873. Knjiga je izašla kao 13. svezak u nizu pod naslovom Geschichte der Wissenschaften in Deutschland, $\mathrm{u}$ kojem je prvi svezak objelodanjen 1864. (do 1913. izašla su 24 sveska).

70

Isto, str. 793 .
} 
»Kako je Hegel mogao razviti, prometnuti čisti bitak u čisti nebitak, iznaći njihovu istotu? Samo tako, da je čisti bitak, koji je bezsubjektan, poredio sa stvarnim bitkom, koji ima za subjekt njeku stvar, n. pr. ČOVJEK jest - pak je našao, da je prema stvarnomu bitku onaj čisti bitak posve prazan, ništav, te je jednak ničemu, nebitku.«

Marković zatim razmatra »obastanak «" ${ }^{71}$ (das Dasein), kao i sljedeću pojmovnu trojku iz Hegelove Znanosti logike, no i ovdje, kao i u daljnjoj raščlambi, dolazi do iste tvrdnje, $\mathrm{tj}$. do istoga prigovora, naime da »razvoj ječnoga pojma u niječni logika ne može čistim mišljenjem dobiti« (str. 105-106), nego da je pri tome svagda »kriomce upotrebljeno opažanje stvarno« (str. 107).

Napokon, Marković posebno rapravlja o dvama, kako kaže, »pokretalima« u Hegelovoj metodi, naime o nijeku i o istovjetnosti, ili istoti.

\subsection{O kakvu je nijeku riječ u Hegelovu misaonome postupku?}

Da bi pokazao »snagu nijeka« (str. 108) u Hegelovoj logici, Marković razmatra ova dva primjera: pojam Nečega (njemački Etwas; Marković ima lik nješto, nječega) te odnos duha i prirode. Nešto je, kaže Marković, »neodređena pojedinka« (str. 106), ili, kako je prvotno bilo zapisano, "pojedinica pojavna «. ${ }^{72}$ Postavlja se pitanje kako se Nešto dalje razvija, recimo jedan krug, koji je jedno takvo Nešto, i ujedno je Nešto koje je ječno. Budući da je svako Nešto, pa tako i navedeni krug, neka pojedinačnost, to znači da ono ima granicu, zapravo njegov bitak ima granicu, a to je, kada je riječ o krugu, njegov obod. Premda je granica nijek bitka Nečega, u ovome slučaju obod je nijek bitka kruga, ta granica, tj. obod, ipak još pripada samomu bivstvu (tj. sućini) kruga. To pak znači da bitak kruga prima u se svoj vlastiti nijek. Bitak Nečega unutar njegovih granica zove Marković samòbitak (njemački Ansichsein), a bitak Nečega izvan njegovih granica zove inòbitak (njemački Anderssein). Prema tome, samòbitak prima u se (svoj vlastiti) inòbitak, što opet znači da se samòbitak i inòbitak poistovjećuju (Marković kaže »istovjete«) i spajaju, pa tako neko određeno Nešto iz svoga samòbitka razvija (svoj vlastiti) inòbitak, tj. mijenja se. Stoga je svako Nešto, budući da je pojedinačno i utoliko ograničeno, ujedno i mjenljivo. Marković taj svoj izvod zaključuje na ovaj način (str. 107): »Tako je Hegel čisto misaonim razvojem samih čistih pojmova, bez ikakva obzira na stvarni sviet, dobio živi svjetovladni pojam neprestane promjene: svako se nješto ili svašto se

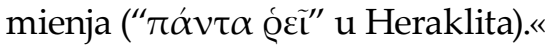

\footnotetext{
71 I to je jedna Markovićeva riječ koju spomenuti rječnici ne navode. 
Valja ipak primijetiti da u navedenome izvodu Marković iznosi samo jednu stranu te »dijalektike« Nečega i Drugoga, koja se »odvija« na njihovoj granici. No u Hegela je pojam granice znatno zamršeniji. Jer granica nije samo nebitak Nečega, u smislu da Nešto (tj. bitak Nečega) prima u se svoj vlastiti nijek, nego je i nebitak toga Drugoga, što znači da njome i Drugo (tj. bitak Drugoga) prima u se svoj vlastiti nijek (jer i Drugo je neko Nešto), a time se zapravo održava (prvo) Nešto kao upravo ono sámo. Hegel naime kaže ovako: ${ }^{73}$

»Etwas also ist unmittelbares sich auf sich beziehendes Dasein und hat eine Grenze zunächst als gegen Anderes: sie ist das Nichtsein des Anderen, nicht des Etwas selbst; es begrenzt in ihr sein Anderes. - Aber das Andere ist selbst ein Etwas überhaupt; die Grenze also, welche das Etwas gegen das Andere hat, ist auch Grenze des Anderen als Etwas, Grenze desselben, wodurch es das erste Etwas als sein Anderes von sich abhält, oder ist ein Nichtsein jenes Etwas; so ist sie nicht nur Nichtsein des Anderen, sondern des einen wie des anderen Etwas, somit des Etwas überhaupt.«

Marković međutim postupa tako, tj. navodi samo jednu stranu spomenute »dijalektike«, jer mu je iznad svega važno pokazati da Hegel u čisto mišljenje »uvlači« prostorne odnose. To se još jasnije vidi kada razmatra drugi primjer nijeka, naime poznatu Hegelovu suprotnost (Marković kaže »suprotak«) $)^{74}$ duha i prirode. Prema Hegelu, veli Marković, »duh je nijek prirode« (str. 110). Ono što za Hegela doista jest, što je ǒv $\tau \omega \varsigma$ óv, isključivo je misao, ili pojam. No priroda također jest, dakle »ima« bitak, jer i ona je misao, ili pojam, samo što to ne zna. Stoga je ona »bezsebna (izvansebna) bezsvjestna misao, bezsvjestni pojam« (str. 108). No misao ne može biti »izvansebna«, jer je ona uvijek »pri sebi«, te je utoliko "prisebna«, ili »usebna«. Zato se u prirodi vidi težnja da bi i ona »došla k sebi«, tj. da bi postala "prisebna«, ili »usebna«. I to je upravo gravitacija: naime težnja prirode da ukloni svoju prostornost, svoju protežnost, ili kako kaže Marković, svoju »razsežnost«, i

73 Vidi Georg Wilhelm Friedrich Hegel, Wissenschaft der Logik I, str. 136. Usp. i hrvatski prijevod (Znanost logike, sv. 1., str. 125): »Nešto je, dakle, neposredno opstojanje koje se odnosi na sebe i ima granice ponajprije kao granice spram Drugoga; ona je nebitak Drugoga, ne sâmog onog Nešto; ono u njoj ograničuje svoje Drugo; - Ali Drugo je sâmo Nešto uopće; granica, dakle, koju nešto [tj. Nešto - B. M.] ima spram Drugoga, također je granica Drugoga kao onog Nešto [tj. kao nekoga Nešto - B. M.], njegova granica kojom ono prvo Nešto drži na odstojanju od sebe kao svoje Drugo, ili je nebitak onog Nešto; tako je granica ne samo nebitak Drugoga, nego i nebitak kako jednog tako i drugog Nešto, a time i onog Nešto uopće.»

74 Riječ suprotak nemaju ni Parčić ni Akademijin rječnik, ali ju donose Šulek (Hrvatsko-njemačko-talijanski rječnik znanstvenoga nazivlja, sv. II., str. 1125) i Filipović (Neues Wörterbuch der kroatischen und deutschen Sprache, sv. 2., str. 1755). Šulek kaže »phil. lat. contrarium, conträrer Gegensatz«, a Filipović samo »konträrer Gegensatz«. Riječ pak suprotica, koja je izvorno pisala (vidi u Dodatku), ne nalazi se ni u jednome od navedenih rječnika. 
da dospije k sebi, tj. u svoje središte. To je središte zapravo matematička točka, što znači potpuni, posvemni nijek prirode, naime njezine prostornosti, ili »razsežnosti«. Kada bi u tome uspjela, priroda bi prestala biti prirodom, ali ona to ne može, upravo nije u stanju, tako reći, $u$ prirodi, nego samo $u$ ljudskome $d u h u$. Drugačije rečeno, »judski duh je priroda u se sabrana, k sebi došla« (str. 109). Taj izvod Marković zaključuje ovako (str. 109-110):

»Dok je priroda bezsebna, razsebna, izvansebna, duh je priseban, useban; on ne teži istom $\mathrm{k}$ svojemu središtu, on ga je dosegao, on je samosvjestan, useban i oseban; duh je dakle misao, i to ne onakova, kakva je misao priroda - koju drugi misli -, nego on je misao, koja sama sebe misli, i koja druge mîsli mïslî (najpače misao prirodinu). Duh je sebi i subjekt i objekt mišljenja iliti i mislilac i mišljenik, dok je priroda samo objekt mišljenja, samo mišljenica, drugomu subjektu - duhu.«

To je na drugi način rečeno ono što Hegel kaže u Enciklopediji: ${ }^{75}$

„Der Geist hat für uns die Natur zu seiner Voraussetzung, deren Wahrheit und damit deren absolut Erstes er ist. In dieser Wahrheit ist die Natur verschwunden, und der Geist hat sich als die zu ihrem Fürsichsein gelangte Idee ergeben, deren Objekt ebensowohl als das Subjekt der Begriff ist."

No budući da je dakle duh nijek prirode, Marković postavlja pitanje o kakvu je nijeku riječ: o porječnome ${ }^{76}$ (kontradiktornome) nijeku, kao što je bijelo - nebijelo, ili o suprotnome (kontrarnome) nijeku, kao što je bijelo - crno. Zatim pruža i odgovor, naime da s Hegelova stajališta nije posrijedi porječan nijek, jer takav bi nijek prirodu u potpunosti uklonio, u potpunosti bi ju porekao, nego da je riječ o suprotnome nijeku, koji umjesto prirode postavlja nešto više, i to nešto više koje je ječno, tj. samoga sebe.

I sada slijedi ključno pitanje (str. 110): »[...] odkud absolutna logika dobiva to ječno (pozitivno) u pojmu duha?« Markovićev je odgovor - »iz opažanja prostornih razlika«, dakle iz iskustva. To se, po Markovićevu mišljenju, vidi upravo po prijedlozima izvan, pri i $u$, jer ti prijedlozi u riječima izvanseban, priseban i useban upravo označuju navedenu suprotnost: priroda je izvansebna, a duh je priseban, ili $u$ seban. Dakle ponovno je riječ o »podmetanju«.

$\overline{75}$ Vidi Georg Wilhelm Friedrich Hegel, Enzyklopädie der philosophischen Wissenschaften im Grundrisse (1830), Dritter Teil: Die Philosophie des Geistes: Mit den mündlichen Zusätzen, str. 17. Usp. i hrvatski prijevod (Enciklopedija filozofijskih znanosti, preveo Viktor D. Sonnenfeld, str. 329): »Duh ima za nas prirodu kao svoju pretpostavku, čija je on istina, a prema tome on je njezino apsolutno prvo. U toj je istini priroda iščezla, a duh se pokazao kao ideja koja je došla do svog bitka-za-sebe, čiji je objekt isto tako kao i subjekt pojam.« 
Razmatrajući različita značenja navedenih prijedoga, Marković upozorava na još nešto. Budući da je priroda prostorna, tj. protežna, njezin bi suprotni nijek i sam morao biti nešto prostorno, dakle protežno, tj. morao bi biti u području prostornosti, kao što suprotno bijelomu i samo mora biti neka boja, no kada o duhu kažemo da je useban, veli Marković, mi to govorimo isključivo metaforički, ${ }^{77}$ jer duh uistinu nije prostoran. Tako se samo kaže, i to u određenoj nalici spram prirode. Mogli bismo dodati, riječ je samo o stanovitoj jezičnoj porabi. Ali to opet znači da posrijedi nije suprotni nijek, kako u prvi mah izgleda u Hegelovu "metodnome postupu «, nego porječni nijek: duh nije suprotak prirodi, nego njezina porjeka ${ }^{78}$ Duh se naime, po Markovićevu mišljenju, uopće ne može dovesti u vezu s prirodom. Stoga Marković, općenito o nijeku u Hegela, iznosi ovakav zaključak (str. 112):

»Dakle glede nijeka kao orudja [\# svoga] kod izvadjanja drugoga pojma iz prvoga, pak četvrtoga iz trećega i t. d., nalazi se absolutna logika u ovoj dilemi: Ili je taj nijek porječan, kontradiktoran (A - non-A), ili je suprotan (kontraran) (A - Z); ako je porječan, to se izmir takovih dvaju pojma nikad ne može naći, iz $\mathrm{A}^{\mathrm{a}}$ i non- $\mathrm{A}^{\mathrm{a}}$ ne može se nikad treći pojam izviti, dakle absolutna logika zastaje ukočena već pri trećem svom koraku, t. j. gdje iz $+\mathrm{A}^{\mathrm{a}} \mathrm{i}-\mathrm{A}^{\mathrm{a}}$ hoće napraviti $\pm \mathrm{A}$. Ili je nijek samo suprotan (kontraran): onda se drugi pojam, suprotan prvome, ne da čistim mišljenjem izviti iz prvoga, nego ga može podati sämo opažanje stvarno; dakle logika absolutna ne može već ni drugi pojam iz prvoga izviti čistim mišljenjem, nego se mora kriomce poslužiti opažanjem, kojega ona tobože ne potrebuje.«

Prema tome, kako god shvatili nijek u Hegelovoj logici (a to znači uopće u Hegelovoj filozofiji), sama ta logika u oba slučaja zastaje, upravo biva ukočenom, i to ili pri trećem koraku, ako pretpostavimo da je nijek porječan (tj. kontradiktoran), ili već pri drugome koraku, ako pretpostavimo da je nijek suprotan (tj. kontraran), no tada joj u pomoć priskače opažanje, bolje reći - ona se njime u tome slučaju potajno služi.

\footnotetext{
77 Marković zapravo kaže »metaforno« (str. 111), a izvorno je pisalo »metaforički«, dakle ispravio je prilog metaforički u metaforno. Vidi i u Dodatku.

78 Ni riječ se porjeka, u takvu liku, tj. u takvu zapisu, ne nalazi u navedenim rječnicima (a ni riječ sriek, u onome slijedu iz Markovićeve Estetike: riek - porjeka - sriek).
} 


\subsection{Je li istota zbiljan spoj pojma i protupojma?}

Tako eto stoje stvari u pogledu nijeka. A kako je s drugim Hegelovim pomagalom »u pokretu dialektične metode « (str. 112), naime s istotom? Marković postavlja pitanje je li moguće da je istota »realna (sbiljna) jednota« (str. 113), tj. onaj viši pojam koji sam sobom »izmiruje suprotnost pojma i protupojma« (str. 112). Njegov je odgovor da to nije moguće, a tu nemogućnost izmira pokazuje na primjeru odnosa (on kaže »medjusobice « $)^{79} » k$ konačnoga (ograničenoga) i nekonačnoga (neograničenoga), relativnosti i absolutnosti« (str. 113). Riječ je najvećim dijelom o odjeljku pod naslovom Die Unendlichkeit u poglavlju Das Dasein Hegelove Znanosti logike. ${ }^{80}$

Markovićev izvod izgleda ovako. Na prvi pogled ono ograničeno (konačno) ima izvan sebe neizmjerje neograničenoga (beskonačnoga), tj. njime je okruženo. Ali to neograničeno i samo je ograničeno upravo tim ograničenim. I sada se ponovno javlja odnos Nečega i Drugoga. Naime ograničeno i neograničeno »dodiruju« se na granici. Granicom, kao nijekom ograničenoga, ono ograničeno »uvlači« u se ono neograničeno; i obrnuto, tom istom granicom, kao nijekom neograničenoga, ono neograničeno »uvlači« u se ono ograničeno. Stoga je ono ograničeno ujedno i neograničeno, a ono neograničeno ujedno i ograničeno (zapravo, neneograničeno). Utoliko je i ograničeno i neograničeno, jedno spram drugoga, istodobno i (neko) Nešto i (neko) Drugo. Oni su istodobno i ograničeni i neograničeni, pa su stoga istovjetni (tako reći, »padaju« u istotu). Time ih, u određenome smislu, čini upravo sama granica. Hegel kaže ovako: ${ }^{81}$

"So abgesondert sind sie ebenso wesentlich eben durch die sie abscheidende Negation aufeinander bezogen. [...] Die Grenze ist aber als die erste Negation, so sind beide begrenzte, endliche an sich selbst. [...] Indem so jedes an

$\overline{79}$ To je jedna od dviju riječi koje Marković rabi u značenju 'odnos'. Druga je uzajmica. O objema vidi potanje u Bojan Marotti, Nazivlje u Markovićevoj Etici, u časopisu Nova prisutnost, str. 487-507, posebice str. 501-502.

80 Vidi Georg Wilhelm Friedrich Hegel, Wissenschaft der Logik I, str. 149-173 (u hrvatskome prijevodu: Znanost logike, sv. 1., str. 137-160). Usp. i u Enciklopediji članke 89-95 u poglavlju Dasein [Enzyklopädie der philosophischen Wissenschaften im Grundrisse (1830), Erster Teil: Die Wissenschaft der Logik: Mit den mündlichen Zusätzen, str. 193-203 (u hrvatskome prijevodu: Enciklopedija filozofijskih znanosti, preveo Viktor D. Sonnenfeld, str. 109-113)].

Isto, str. 153-154. Usp. i hrvatski prijevod (isto, str. 142-143): »Tako odvojeni oni se jednako tako bitno međusobno odnose upravo posredstvom negacije koja ih odvaja. [...] Ali granica je kao prva negacija, pa tako oboje jesu ono ograničeno, ono konačno po samom sebi. [...] Time što svako od njih na sebi samome i iz svoje odredbe jest postavljanje svojeg Drugog, oni su nerazdvojni. [...] Time je određen način pojave tog jedinstva; postavljeno u opstojanju, ono je kao neko preokretanje ili prelaženje konačnog $\mathrm{k}$ beskonačnom i obrnuto, tako da se ono beskonačno na konačnome i konačno na beskonačnome, Drugo na Drugome, samo pojavljuje [...].« Naslov je toga pododjeljka Wechselbestimmung des Endlichen und Unendlichen (str. 151), tj. Uzajamno određivanje konačnog i beskonačnog (str. 140). 
ihm selbst und aus seiner Bestimmung das Setzen seines Anderen ist, sind sie untrennbar. [...] Dadurch ist die Weise der Erscheinung dieser Einheit bestimmt; im Dasein gesetzt ist sie als ein Umschlagen oder Übergehen des Endlichen zum Unendlichen und umgekehrt; so daß das Unendliche an dem Endlichen und das Endliche an dem Unendlichen, das Andere an dem Anderen, nur hervortrete [...]..

Svoj pak izvod Marković zaključuje ovim riječima (str. 114):

»Ograničeno i neograničeno dakle je istovjetno: $\tilde{v} v=\pi \tilde{\alpha} v$. U jednom je biću vasionstvo, a u vasionstvu je svako pojedino. Relativni duh postaje absolutnim, a absolutni bitkuje u pojedinih relativnih, t. j. bog je immanentan svietu, bog je $\mathbf{u}$ svietu, nije izvan svieta. To je Hegelov pantheisam.«

Ali, ta "poistovjetba«, po Markovićevu mišljenju, ne stoji. A ne stoji zato što je ona, tj. ta istovjetnost ograničenoga i neograničenoga, konačnoga i beskonačnoga, relativnoga i apsolutnoga "puka izjednačba dviju mirujućih misli, a nije zbiljstvena spojitba, nije pronik absolutnoga $u$ relativno, ni razmak relativnoga $u$ absolutno« (str. 115). K tomu, pita se dalje Marković, je li uopće ta istovjetnost mogla niknuti iz čiste misli? I odmah odgovara da nije, nego da je i ona dobivena iz opažajnih pomisli, naime iz opažanja prostornih razlika. Tako se i u temelju nijeka i u temelju istote, kako smatra Marković, uistinu nalazi opažanje.

\section{5. »Nelogičnost« apsolutne logike}

No apsolutna je logika ujedno i posve »nelogična«, tj. njezin postupak nije $u$ skladu s logikom, i to zato, kako kaže Marković, što »pravi one pogrješke u doumljivanju, koje se zovu paralogismi« (str. 116). Marković rabi riječ doumljivanje u značenju 'zaključivanje' (no izvorno je i pisalo zaključivanje, tj. »u zaključivanju«, pa je potom tu riječ precrtao te iznad nje napisao »doumljivanju«). ${ }^{82} \mathrm{~K}$ tomu, redovito ima doumak u značenju 'zaključak' (kao jedan od triju oblika misli), ${ }^{83}$ a riječ zaglavak u značenju 'konkluzija' (u tome se značenju katkada rabi i riječ zaključak, posebice na razgovornoj razini). Premisu pak Marković obično zove prednjakom.

82 Vidi u Dodatku.

83

Akademijin rječnik ne donosi riječ doumak, no Šulek, Filipović i Parčić navode i doum i doumak. Za doum Šulek kaže »phil. lat. ratiocinium, mittelbarer Schluß«, a za doumak »phil. lat. syllogismus, der eigentliche Schluß«, te navodi velik broj sveza uz jednu i uz drugu riječ (Hrvatsko-njemačko-talijanski rječnik znanstvenoga nazivlja, sv. I., str. 240). Filipović ima slično, za doum »mittelbarer Schluß«, a za doumak »der eigentliche Schluß (Neues Wörterbuch der kroatischen und deutschen Sprache, sv. 1., str. 173), dočim Parčić za doum veli »pensata, trovata, invenzione; induzione«, a za doumak »argomentazione; (log.) sillogismo« (Vocabolario croato-italiano, str. 124). Navodi k tomu i verižni doumak (sorite) te kriv doumak (paralogismo). Riječ doum tvorena je prema doumiti kao naum prema naumiti. 
Dakle, apsolutna logika griješi, tj. Hegel griješi u zaključivanju, iliti doumljivanju, a bolje bi bilo reći da pri doumljivanju ne poštuje logičke zakone, koje je već, kako kaže Marković, postavio Aristotel, i svi ih filozofi do danas priznaju, »samo Hegelova absolutna logika ne priznaje i navlaš vriedja te zakone« (str. 116). Da bi pokazao u kojoj mjeri apsolutna logika, tj. sam Hegel, »vriedja« logičke zakone, Marković razmatra drugi »silogismeni lik« (tj. figuru), te navodi i poznatu formulu, ili, kako kaže, »oblikovinu « ${ }^{84}$ za taj lik (str. 116):

$$
\begin{aligned}
& P \pm M \\
& S \mp M \\
& \hline S-P
\end{aligned}
$$

Pri tome Marković iznosi i pravila koja vrijede posebno za tu figuru, pa kaže ovako (str. 116): »[...] u drugom silogismenom liku zaglavak je svagda niječan, i svagda je jedan prednjak niječan a drugi ječan. Nikada se po drugom silogismenom liku ne može dobiti ječan zaglavak.« Dakako, to su pravila koja se mogu lako izvesti iz općih pravila za valjan silogizam. Poznato je naime da u silogizmu srednji pojam mora barem $u$ jednoj premisi (ili $u$ jednome prednjaku) biti raspodijeljen, tj. mišljen u cijelome svome opsegu. Budući da se u drugoj figuri srednji pojam nalazi na mjestu predikata (ili priroka), to znači da barem jedan prednjak mora biti niječan, kako bi taj srednji pojam mogao biti raspodijeljen. A ako je jedan prednjak niječan, opet prema općim pravilima za valjan silogizam, i zaglavak mora biti niječan.

No upravo protiv navedenih pravila griješi Hegel, jer po drugome »silogismenome liku« izvodi ječne zaglavke, i to iz dvaju ječnih prednjaka. Marković navodi i primjer (str. 117):

1. Čisti bitak je najprazniji (najabstraktniji) pojam;

2. Ništa je najprazniji pojam;

3. Dakle: Ništa je čisti bitak, i obratno: čisti bitak je ništa.

84 Riječ oblikovina nemaju ni Parčić ni Akademijin rječnik, no navode ju Šulek (Hrvatsko-njemačko-talijanski rječnik znanstvenoga nazivlja, sv. II., str. 684) i Filipović (Neues Wörterbuch der kroatischen und deutschen Sprache, sv. 1., str. 851), ali ne u značenju 'formula'. Šulek kaže »tech. Rundholz, frc. bois en grume, egl. round timber«, a Filipović ima samo »Rundholz«. Kao prijevod za riječ formula pokojni je profesor László rabio riječ obrazica. Vidi npr. Bulcsú László, Pabirci redničnoga i obavjèstnîčkôga pojmovlja oko razumnih sustava, u zborniku Obrada jezika i prikaz znanja, uredili Slavko Tkalac i Miroslav Tuđman, Zavod za informacijske studije, Zagreb, 1993. Usp. ovu rečenicu (str. 25): »Brojitba je ustànovba količinê pojavaka jednoga te istoga datka, a izračun je preoblika brojnih dataka po datoj obrazici (formula).« Inače za Schlußfigur (grčki $\sigma \chi \tilde{\eta} \mu \alpha$ ) Šulek ima oblik douma, a za Schlußweise (latinski modus) način douma (vidi pod doum, sv. I., str. 240). 
To je isto, veli Marković, kao kada bi netko iz sudova »C je slovo« $\mathrm{i} \gg C ̌$ je slovo« izveo zaglavak »C je $\check{C}$ (str. 116). Tu pak navodi i jednoga hegelovca, Karla Rosenkranza (1805. - 1879.), ${ }^{85}$ i njegovu logiku pod naslovom Wissenschaft der logischen Idee, kojoj je prvi svezak objelodanjen 1858. (Metaphysik), a drugi 1859. (Logik und Ideenlehre), i to zato što »Rosenkranz u svojoj logici veli na jednom mjestu: izreka, da je bitak i nebitak isto, istinita je, jer ni bitku ni nebitku ne može se prireći nikakav predikat« (str. 117). Evo kako to kaže sam Rosenkranz: ${ }^{86}$

»In dem Begriff des einfachen Nichts ist offenbar nichts zu denken, als die Bestimmungslosigkeit. In dieser ist es mit dem reinen Sein identisch, aber für sich ist es von ihm unterschieden. Wenn man daher sagt: Sein und Nichtsein seien dasselbe, so kann dies einen richtigen Sinn haben, nämlich, daß von beiden nichts ausgesagt werden könne.«

No da bi potanje objasnio svoje stajalište, Rosenkranz odmah dodaje i ovo: ${ }^{87}$ »Wollte man aber jene Identität von Sein und Nichtsein so verstehen, als ob Dasein und Nichtdasein identisch wären, so würde dies ein großer Irrthum sein.«

Naravno, dodaje Marković, Hegel je u potpunosti svjestan tih (svojih) paralogizama, tih pogrješnih doumaka, ali tvrdi »da su ti zakoni zastarjeli i da ne vriede ništa« (str. 117). Usuprot takvu gledištu, Marković zaključuje da ti zakoni

$\overline{85}$ Rosenkranz je godine 1833. postao profesorom u Königsbergu. Poznat je po tome što je napisao veliki Hegelov životopis (Georg Wilhelm Friedrich Hegel's Leben, beschrieben durch Karl Rosenkranz, Verlag von Duncker und Humblot, Berlin, 1844.). Obično ga svrstavaju u tzv. »Hegelovsku desnicu«, premda neki smatraju da, zajedno s Karlom Ludwigom Micheletom (1801. - 1893.), koji je bio profesor u Berlinu, pripada »sredini«, tj. da se nalazi između »desnoga« hegelovca Johanna Eduarda Erdmanna (1805. - 1892.), profesora u Halleu, s jedne strane, te skrajnje »Hegelovske ljevice«, poput Bruna Bauera (1809. - 1882.) i Ludwiga Feuerbacha (1804. - 1872.), s druge. O »Hegelovskoj desnici« vidi zbornik Die Hegelsche Rechte: Texte aus den Werken von F. W. Carové, J. E. Erdmann, K. Fischer, E. Gans, H. F. W. Hinrichs, C. L. Michelet, H. B. Oppenheim, K. Rosenkranz und C. Rössler, ausgewählt und eingeleitet von Hermann Lübbe, Friedrich Frommann Verlag (Günther Holzboog), Stuttgart-Bad Cannstatt, 1962. O Rosenkranzovu »mjestu « među »desnim « hegelovcima te o njegovim sličnostima i razlikama prema Micheletu i Erdmannu vidi Lübbeov Einleitung (str. 7-17), posebice str. 14-17. $\mathrm{Za} »$ Hegelovsku ljevicu« usp. zbornik Die Hegelsche Linke: Texte aus den Werken von Heinrich Heine, Arnold Ruge, Moses Hess, Max Stirner, Bruno Bauer, Ludwig Feuerbach, Karl Marx und Sören Kierkegaard, ausgewählt und eingeleitet von Karl Löwith, Friedrich Frommann Verlag (Günther Holzboog), Stuttgart-Bad Cannstatt, 1962., te osobito Löwithov Einleitung pod naslovom Philosophische Theorie und geschichtliche Praxis in der Philosophie der Linkshegelianer (str. 7-38).

Vidi Karl Rosenkranz, Wissenschaft der logischen Idee, Verlag der Gebrüder Bornträger, Königsberg, 1858., sv. 1. Metaphysik, str. 122.

Isto. Osim Rosenkranzove, Markovićjoš spominje sljedeće hegelovske logike (i ujedno logičare): Karl Werder, Logik: Als Commentar und Ergänzung zu Hegels Wissenschaft der Logik, Erste Abtheilung, Verlag von Veit und Comp., Berlin, 1841.; Johann Eduard Erdmann, Grundriss der Logik und Metaphysik: Für Vorlesungen, Zweite, verbesserte Auflage, Bei Johann Friedrich Lippert, Halle, 1843.; Kuno Fischer, Logik und Metaphysik oder Wissenschaftslehre: Lehrbuch für akademische Vorlesungen, C. P. Scheitlin's Verlagshandlung, Stuttgart, 1852. 
ipak vrijede, jer osim što se u tome slažu svi, od Aristotela do Milla, tomu svjedoči i »naravski razum svakoga čovjeka« (str. 117). Naime, pita se Marković, tko bi izvodio onakav zaglavak, da je $\mathrm{C}=\check{C}$ ? Pa odgovara: eto, Hegel bi. I potom, nakon što je razmotrio još nekoliko primjera takva (pogrješnoga) doumljivanja, zaključuje taj šesti odsjek, ostavlja Hegelovu filozofiju, smatrajući da je pružio dostatne dokaze kako je postupak apsolutne logike sam u sebi »nelogičan«, i vraća se potom na sustavnu izvedbu svoje logike.

\section{Temeljno obilježje Markovićeve kritike Hegela}

Kažem, Marković »ostavlja Hegelovu filozofiju«, a možda bi trebalo reći »ostavlja Hegelovu filozofiju s primjetnim olakšanjem«, jer valja uočiti da se u cijelome tome šestome odsjeku, koji je posvećen kritici Hegelove logike, osjeća određen Markovićev »otpor « prema Hegelu, i to ne samo prema »absolutnoj logici« nego i prema Hegelovoj filozofiji u cjelini. Kako sam kaže, prema toj »pretvorbi logike u metafiziku«.

No upravo to i jest Hegelova filozofija, ta "pretvorba«, naime to da je logika zapravo metafizika. A kako smo vidjeli, to je ono što Marković nikako ne može prihvatiti. I po tome u potpunosti pripada protuhegelovstvu, što je jedno od temeljnih obilježja tadanje »austrijske« filozofije, tzv. »austrijskoga realizma«, koji postupno nastaje u drugoj polovici devetnaestoga stoljeća, recimo na crti Prag - Beč - Graz - Zagreb, a kojemu je središnja osoba Franz Brentano. Začet je međutim ranije, još u prvoj polovici stoljeća, izvanredno važnim radovima velikoga Bernarda Bolzana.

To će zacijelo biti razlogom, naime taj spomenuti »otpor « prema Hegelu, da Marković, prilikom kritike pojedinih Hegelovih stavaka, ne uzimlje svagda u obzir cjelinu Hegelova izvoda, nego kadšto iznosi samo jednu »stranu«, ili jedan »aspekt« te cjeline, kao primjerice pri tumačenju »dijalektike« Nečega i Drugoga, koja se »odvija« na njihovoj granici, ili pak neprihvaćanjem onoga što se uobičajeno zove istovjetnošću istovjetnosti i razlike (identitetom identiteta i diferencije), o čem je već bilo riječi. A ipak, »Das Wahre ist das Ganze«, veli Hegel u Fenomenologiji duha. ${ }^{88}$ Dakako, Marković to zna, ali, reklo bi se, namjerno

88 Vidi Georg Wilhelm Friedrich Hegel, Phänomenologie des Geistes, 1970. (sv. 3. u izdanju Werke in zwanzig Bänden), str. 24 (Vorrede). Usp. i hrvatski prijevod [Fenomelogija duha, preveo Viktor D. Sonnenefeld, pogovor napisao Vladimir Filipović, Kultura, Zagreb, 1955., str. 14 (Predgovor)]: »Istinito je cjelina.« Doslovno bi bilo »Ono istinito je (ono) cijelo«, ili »Ono istinito je (ono) čitavo«, ili pak »Ono istinito je (ono) svo«, ali obično se veli »Istina je cjelina«. Potonje bi se moglo reći i »Istina je svota«, prema onome što za das Gesammte i das Ganze imaju Šulek (Hrvatsko-njemačko-talijanski rječnik znanstvenoga nazivlja, sv. II., str. 1135) i Filipović (Neues Wörterbuch der kroatischen und deutschen Sprache, sv. 2., str. 1774). 
toj »logici koja je pretvorena u metafiziku« pristupa samo iz logičkoga obzora, a ne istodobno i iz onoga metafizičkoga. Drugačije rečeno, knjigu kojoj je naslov Wissenschaft der Logik, Marković kritizira isključivo logički i samo joj s toga gledišta upućuje prigovore. A činjenicu da je posrijedi zapravo metafizika, jednostavno ne prihvaća. Bolje reći, ne želi na to pristati. Ili pak, ako se tako hoće, ne želi se (ili se ne može) »otvoriti« za jednu takvu misao.

Bitno je međutim uvidjeti da je, usprkos svemu tomu, Markoviću posve jasno da se mora (filozofski) »odrediti« prema Hegelu, u svakome slučaju prema njegovoj logici, ali ujedno i prema njegovoj filozofiji u cjelini. Jer to je upravo ono što kaže i u svojoj Estetici: ${ }^{89}$

»Ali razmatrajući poviestni razvoj estetike, [...], ne možemo na ino, a da te činjenice iliti pojedine glavne smjerove i nazore u dosadašnjoj estetici ne objasnimo kratkom oznakom i onih raznih filozofijskih sustava, iz kojih su razni smjerovi estetike nikli, pak da te razne nauke $u$ estetici ne prosudimo kritičkim načinom, budući da bi puko prikazivanje prošastih nazora i smjerova a bez kritike njihove bilo i bezplodno i gotovo nemoguće.«

Takvim se svojim pristupom povijesti filozofije razlikuje od mnogih protivnika Hegelova filozofiranja, dakle od mnogih protuhegelovaca, koji se, kako to inače često biva, uopće ne žele baviti Hegelovom filozofijom. Napokon, to i jest ono, među ostalim dakako, što Markovića čini jednim od temeljnih filozofa u novijoj hrvatskoj filozofiji (»novijoj«, to pak znači: u hrvatskoj filozofiji koja je pisana hrvatskim jezikom). Onim filozofom, naime, od kojega ta »novija« filozofija i započinje.

89 Vidi Franjo Marković, Razvoj i sustav obćenite estetike, str. 42. 


\section{DODATAK}

\section{Uvodna bilješka}

Spomenuto je već da se rukopis Markovićeve Logike čuva u Arhivu Hrvatske akademije znanosti i umjetnosti u Zagrebu, i to autograf pod oznakom XV 37/1, a pod oznakom XV 37/2 šest litografiranih primjeraka $(a-f)$, od kojih je najopsežniji onaj s oznakom $2 a$ (obaseže oko 820 str.). ${ }^{90} \mathrm{U}$ ovome se Dodatku nalazi (priređeni) prijepis šestoga odsjeka uvodnoga dijela Markovićeve Logike pod naslovom Razlozi proti absolutnoj logici, i to iz litografiranoga primjerka $2 a$ (str. 94-119). Stranice izvornika u prijepisu se navode u kosim zagradama. Prethodno je međutim potrebno reći nešto o načelima priređivanja Markovićeve Logike u cjelini.

Prije svega, čitav je rukopis Logike upisan u računalo, i to prema litografiranome primjerku $2 a$. $\mathrm{U}$ tome se primjerku nalaze i neki dijelovi kojih nema ni $\mathrm{u}$ autografu, a u njem ima i najviše unesenih Markovićevih ispravaka i dopuna. Pojedini se naime litografirani primjerci uzajamno razlikuju po potpunosti te po količini ispravaka. Potonjih ima najviše u primjercima $a, b$ i $c$. Ispravci su i dopune, kako je već rečeno, pisani Markovićevom rukom.

Budući da je namjera objaviti kritičko izdanje Logike, osim temeljnoga teksta, u bilješkama treba naznačiti i sve razlike prema temeljnome tekstu koje se nalaze $\mathrm{u}$ onim litografiranim primjercima u koje je Marković unosio ispravke, kao i sve razlike između temeljnoga teksta (tj. litografiranoga primjerka 2a) i Markovićeva autografa. Što se pak tiče ispravaka i dopuna u samome litografiranome primjerku $2 a$, one ulaze $\mathrm{u}$ »temeljni tekst«, tj. one se smatraju »posljednjim zahvatom«, dakle posljednjom potvrđenom voljom Franje pl. Markovića, a to je ono što prema tekstološkim pravilima mora imati prednost. Dakako, ono što je pisalo prije ispravka, ukoliko se može pročitati, također se unosi u bilješke, kao i oni dijelovi teksta koje je Marković precrtao (ti se dijelovi kadšto moraju unijeti u bilješke, ali katkada se mogu i ostaviti u temeljnome tekstu, uz posebnu oznaku, o kojoj će još biti riječi, da ih je Marković precrtao). U ulomku iz Logike koji ovdje donosim, ne navodim u bilješkama ispravke koje je Marković unosio u drugim primjercima, a ne navodim

$\overline{90}$ Ova se Uvodna bilješka ne razlikuje bitno od Uvodne bilješke koja se nalazi u mome članku O pojmu znaka u Markovićevoj Logici, u spomenutome zborniku Filozofijsko djelo Franje pl. Markovića, priredio Stipe Kutleša, Matica hrvatska, Zagreb, 2016., str. 94-100, i to prije sedmoga odsjeka uvodnoga dijela Markovićeve Logike (pod naslovom Psihologijska podloga logici), što ga ondje donosim kao prilog. Usporedna je i poglavlju pod naslovom Rukopis Markovićeve Logike u mome članku O Markovićevim filozofskim rukopisima u arhivima HAZU, u časopisu Civitas Crisiensis, vol. 2., 2016., str. 119-124., gdje kao prilog donosim prvi odsjek Sustava logike pod naslovom O riečih. K tomu, usporedna je i poglavlju O načelima priređivanja u mome pogovoru pod naslovom Franjo pl. Marković u knjizi: Franjo pl. Marković, Etika, kritičko izdanje priredio i pogovor napisao Bojan Marotti, Matica hrvatska, Zagreb, 2016., str. 224-228. To je dakako razumljivo, jer je riječ o istovjetnim načelima priređivanja. 
ni razlike prema autografu. To znači da se »krećemo« isključivo unutar primjerka $2 a$, pa nije potrebno posebno pripominjati da se određeni ispravak tiče upravo primjerka $2 a$ (a ne kojega drugoga), što opet znači da se taj primjerak uzimlje by default (tj. »navodi se nenavodom«). Dakako, u cjelokupnome kritičkome izdanju trebat će svagda naznačiti o kojem je primjerku riječ, kao i to je li možda riječ o autografu. Valja također pripomenuti da se Markovićev jezik beziznimno poštuje, i to kako na slovničnoj, tako i na pravopisnoj i na slovopisnoj razini.

Kritičko se izdanje Markovićeve Logike priprema u osnovi na isti način kako je priređen i Lexicon Latino-Illyricum Pavla Rittera Vitezovićeva. ${ }^{91}$ Tada sam temeljno načelo prema kojem je priređen Vitezovićev rukopisni rječnik, bio nazvao »načelom najveće moguće kritičnosti.$^{92}$ To bi značilo, mutatis mutandis, da sve ono što je na određeni način zapisano u primjerku $2 a$, mora tako biti otisnuto i u samome izdanju, dočim svako odstupanje od rukopisnoga izvornika mora u izdanju biti posve jasno naznačeno kao prirediteljev zahvat. Pri tome se javljaju dva posebna pitanja, naime Markovićevi ispravci koje je naknadno unosio, te precrtani dijelovi teksta. Evo kako to izgleda na jednome primjeru. Prve dvije Markovićeve rečenice u njegovoj rukopisnoj Logici (u litografiranome primjerku 2a) glase ovako:

Gospodo! Logika je, da rečem u prispodobi, kormilo na onoj putničkoj ladji, što no ju ljudski um otiskuje po bezkrajnoj pučini mislî, dogadjajâ i pojavâ put uviek željno izgledane istine, dobrote i ljepote.

To je ono što je izvorno pisalo, tj. što je, vjerojatno, neki slušač (ali možda i tkogod drugi) prepisao iz Markovićeva autografa. Međutim Marković je prvu rečenicu (upravo prvu riječ) »Gospodo!« precrtao, smatrajući očevidno da to obraćanje slušačima nije potrebno unositi u samo izdanje (koje je, kako sam već spomenuo, zacijelo pripremao), potom je dio »da rečem u prispodobi« također precrtao, ali je iznad napisao »reć bi«, te je zatim u riječi »kormilo« precrtao prvo o slijeva. U kritičkome će izdanju stoga biti ovako:

[\# Gospodo!] Logika je, reć bi, krmilo ${ }^{1}$ na onoj putničkoj ladji, što no ju ljudski um otiskuje po bezkrajnoj pučini mislî, dogadjajâ i pojavâ put uviek željno izgledane istine, dobrote i ljepote.

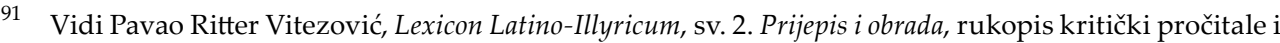
rječnik upisale Zrnka Meštrović i Nada Vajs, priredio i predgovor napisao Bojan Marotti, 2010. Vidi također moj predgovor tomu kritičkomu izdanju pod naslovom Kako je priređen Vitezovićev Lexicon Latino-Illyricum, str. V-CL.

92 Vidi spomenutomi predgovor Vitezovićevu Lexiconu, str. V.
} 
Dakle sve ono što je precrtano (a može se pročitati), navodi se u uglatim zagradama nakon "plota« (\#). U bilješci će pak pisati ovo:

${ }^{1}$ reć bi, krmilo : da rečem u prispodobi, kormilo

Uočiti je da dvotočje (:), pisano s razmakom s lijeve i s desne strane, pri tome znači 'prethodno je pisalo', ili 'prema', pa cjelinu treba pročitati ovako: " reć bi, krmilo", a prethodno je pisalo "da rečem u prispodobi, kormilo"«, ili: »"reć bi, krmilo" prema "da rečem u prispodobi, kormilo"«.

A evo i jedan primjer iz ovoga, šestoga odsjeka. Na str. 101. u litografiranome primjerku $2 a$ pisalo je ovako:

Pojam postajanja dobiven je osjetnim opažanjem zbiljnih promjenljivih pojavnih stvari, pak je odatle a ne iz čistoga mišljenja kriomce primetnut čistomu bitku i nebitku.

No Marković je iznad »dobiven« napisao »doznan«, a riječ je »dobiven« stavio u zagrade. Zatim je »ne« ispravio u »nije«, precrtao »iz«, pa označio da na tome mjestu valja umetnuti »domišljen samim«, potom ispravio »čistoga« $u$ »čistim« $\mathrm{i}$ »mišljenja $\mathrm{u}$ »mišljenjem«, te napokon obilježio da čitav novi odsječak »a nije domišljen samim čistim mišljenjem « treba prebaciti na kraj rečenice, i to nakon zareza koji je dodao iza riječi »nebitku«. Stoga će u kritičkome izdanju biti ovako (a tako je i ovdje, u priređenome šestome odsjeku):

Pojam postajanja doznan (dobiven) je osjetnim opažanjem zbiljnih promjenljivih pojavnih stvari, pak je odatle kriomce primetnut čistomu bitku i nebitku, a nije domišljen samim čistim mišljenjem. ${ }^{1}$

U bilješci će pisati ovo:

${ }^{1}$ kriomce primetnut čistomu bitku i nebitku, a nije domišljen samim čistim mišljenjem : a ne iz čistoga mišljenja kriomce primetnut čistomu bitku i nebitku

Primijetiti je da se u bilješci posebno ne naznačuje da je riječ »doznan« umetnuta naknadno, kao ni to da su i zagrade uz riječ »dobiven « naknadno dodane, tj. ne navodi se kako bi ta rečenica glasila bez tih (naknadnih) umetaka. Slično vrijedi i za Markovićeve ispravke različitih omaha u zapisu (kada je dakle posrijedi pisateljev lapsus calami). Stoga se dva navedena slučaja mogu smatrati svojevrsnim iznimkama u odnosu na ono što je rečeno, tj. da se u bilješkama redovito donose sve razlike prema temeljnome tekstu, dakle sve ono što je izvorno pisalo. No ostale se razlike, ma koliko se mogle činiti neznatnima, redovito naznačuju. 
Ako je Marković kojim slučajem štogod ispravljao dva puta, navode se (u prirediteljevoj bilješci) oba ispravka (tako reći, svi »slojevi« ispravljanja), svagda nakon dvotočja, i to prema ovakvu redoslijedu:

drugi ispravak : prvi ispravak : izvorni zapis

To znači da se ono što je bilo prvo napisano, u prirediteljevoj bilješci navodi na posljednjem mjestu. Dakako, u temeljni se tekst uvršćuje drugi ispravak, jer je to ono što je učinjeno posljednje [»posljednji zahvat«, ili "posljednja (Markovićeva) volja«]. Tako je primjerice na stranici 109. u litografiranome primjerku $2 a$ izvorno pisalo sljedeće:

Ali priroda je bezsebna (izvansebna) bezsvjestna misao, bezsvjestni pojam, budući pak da misao ne može pravo biti bezsebna, izvansebna, nego samo prisebna (prisobna), [...].

No Marković je najprije precrtao riječ »(prisobna)«, koja je unutar zagrada, pa iznad nje napisao »(usobna)«, također unutar zagrada, da bi zatim slovo $o$ ispravio $\mathrm{u} e, \mathrm{tj}$. »preko « $o$ napisao $e$. Stoga će u kritičkome izdanju biti ovako (a tako je i ovdje, u priređenome šestome odsjeku):

Ali priroda je bezsebna (izvansebna) bezsvjestna misao, bezsvjestni pojam, budući pak da misao ne može pravo biti bezsebna, izvansebna, nego samo prisebna (usebna), ${ }^{1}[\ldots]$.

A u bilješci će pisati ovo:

${ }^{1}$ (usebna) : (usobna) : (prisobna)

Općenito se može reći da se svaki prirediteljev pripomenak navodi u uglatim zagradama. $\mathrm{K}$ tomu, u uglatim se zagradama također navodi svako (prirediteljevo) pridodavanje pisménā (slova, brojaka, razgodaka). ${ }^{93}$ Suprotno tomu, suvišna se pismena nalaze u prelomljenim zagradama. $U$ kosim se zagradama navodi broj stranice u izvorniku (tj. u litografiranome primjerku 2a). Uskličnik u uglatoj zagradi znači da u izvorniku piše upravo tako. Evo kako to izgleda u preglednici:

$\overline{93}$ Rabim riječ písme otprilike u značenju engleskoga character, kako se danas obično nazivlje pojedini znak u nekome pismeníku (engleski font). Za takvu porabu vidi Bulcsú László, Pabirci redničnoga $i$ obavjèstnîčkôga pojmovlja oko razumnih sustava, u zborniku Obrada jezika i prikaz znanja, uredili Slavko Tkalac i Miroslav Tuđman, str. 11-73. I Parčić za pisme, uz lettera (dell'alfabeto), ima carattere (da stampa), a za hrvatsku riječ pismenik navodi talijansku otpovjednicu cassa de' caratteri (Vocabolario croatoitaliano, str. 642). Riječ je pisme $\mathrm{k}$ tomu i hrvatski prijevod za ono što se u jezikoslovlju zove grafem. 


\begin{tabular}{|c|c|}
\hline ZNAK & ZNAČENJE \\
\hline[] & pridodana pismena; prirediteljev \\
pripomenak
\end{tabular}

Napokon, $\mathrm{u}$ rukopisnome su primjerku $2 a$ neka pismena mjestimice pisana krupnije, katkada su podcrtana, kadšto su krupnija i podcrtana, a gdjegdje su opet dvaput podcrtana. Kako se to razlikuje u izdanju, pokazuje ova preglednica:

\begin{tabular}{|c|c|}
\hline RUKOPIS & IZDANJE \\
\hline krupna pismena & masna pismena \\
\hline podcrtana pismena & kosa pismena \\
\hline krupna i podcrtana pismena & masna $\boldsymbol{i}$ kosa pismena \\
\hline dvaput podcrtana pismena & SMANJENA VELIKA PISMENA \\
\hline
\end{tabular}

Donosim sada u cjelini taj šesti odsjek uvodnoga dijela Markovićeve Logike. 
/str. 94/

\section{ŠESTI ODSJEK.}

\section{RAZLOZI PROTI ABSOLUTNOJ LOGICI.}

\section{§1. Obilježje absolutne logike Hegelove.}

Pošto je Heraklit učio, da je vječita neprestana promjena jedino stalno i bićno (substancijalno) u svietu (dakle Preradovićeva izreka: »stalna na tom svietu samo miena jest« izvorno je misao Heraklitova); a Elejska škola učila protivno, da je jedno jedino, vječito, nepromjenljivo, beztvarno biće, koje ima sámo pravi bitak, a da su sve pojedinačne tvarne promjenjive stvari puki prolazni prividi bez bitka: Platon je postavio nauku, koja nadovezuje na one dvie medjusobom suprotne. Biće tj. nješto, što ima nepromjenjiv vječit bitak, ne može biti tvarno, jer što je tvar, neprestano se mienja. Nad tvarju ima netvarnih/str. 95/ idejâ, koje i jesu prava bića, jer su vječite, nepromjenjive. Svaki naš pojam, n. pr. pojam o stolu, o kući, o čovjeku, ima pralik svoj u ideji, koja sve pojmove oznake u sebi drži, ali tako, da ta ideja kao beztvaran pralik pojmov nije puka misao duha ljudskoga ili božanskoga, nego je posebno i samostalno beztvarno biće, ter ima bitak vječit i nepromjenjiv; ideja iliti pojmovina stola, čovjeka, biljke i t. d. obstoji kao biće od vieka do vieka u nadnebesju. Same tê pojmovine imaju pravi i zbiljni bitak, same one su cjelokupno tò ôv,

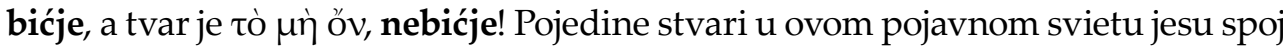
tvari i ideje (pojmovine), nebića i bića; n. pr. tvarni stol nosi na sebi palik, sliku pojmovine iliti ideje stolove, jer on podpada pod obći pojam stola i nosi na sebi obilježne oznake toga pojma; i samo po tom ima tvarni stol bitak, što je slika iliti palik pralika svoga t. j. idealnoga, bićnoga stola; u koliko pak tvarni stol ima i tvar (drvenu, kamenu i t. d.), on je nebićan, promjenjiv, prolazan; kad se sažge njegova drvena tvar, ${ }^{94}$ onda ona prima sliku druge ideje, druge pojmovine, pojmovine pepela te tako nestaje pojedinačni /str. 96/ tvarni stol kao palik pralika stola, ali taj pralik, ideja iliti pojmovina stola ostaje i nadalje vječito, nepromjenljivo. Tako je sav ovaj tvarni pojavni sviet spojevina idejâ i tvari, bićja i nebićja. Platon je dakle

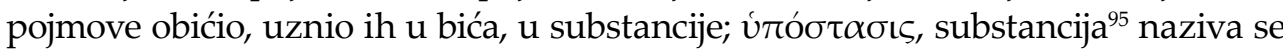
ono biće, koje stoji i obastaje vječito pod pojavnom prolaznom tvari. U srednjem vieku skolastični filosofi nadovezaše na tu nauku, razvijajući dva suprotna smjera. Jedni vele, da pojmovi nisu bića nego da su puke misli naše, koje su u riečih izra-

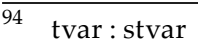

95 substancija : substancijom
} 
žene; n. pr. pojam stola da nema nikakova samostalna ${ }^{96} \mathrm{i}$ prava ${ }^{97}$ bitka nego obstoji samo u rieči, koja ga izražava; ${ }^{98}$ bitak imadu samo pojedine stvari, a pojam je puka rieč, »nomen « - po tom se zove ta škola nominalističkom. Drugi vele: pojmovi, i to vrstni pojmovi, npr. pojam čovjeka kao vrsti, imaju pravi i podpun ${ }^{99}$ bitak; ti pojmovi nisu puke misli, puke rieči, nego su bića, res; zato se ta škola zove realističnom u ovom, sada rečenom smislu. Po toj školi pojedinačni čovjek ima bitak samo po onom, što je na njem vrstno-pojmovno, obćenito ljudsko, a što je na njem pojedinačno, osobinsko, to ni nema bitka, to je prolazno; jer samo vrst obastaje, dok pojedinac nestaje. /str. 97/

$\mathrm{Na}$ Platonovu nauku, da su ideje ili pojmovine t. j. obićeni pojmovi prava bića, i na sholastičnu realističnu nauku, da su sami pojmovi prave stvarevine, res t. j. bića, nadovezuje Hegelova nauka absolutne logike.

Čisti pojam njeke stvari, to jest pojam njezin odlučen od svih osjetivih oznakâ njezinih, nije samo bivstvo (essencija), nego je i bitak (eksistencija) tê stvari. Čista misao o stvari, odlučena (abstraktna) od svih osjetnih pomišljaja stvari, nije od stvarî $\hat{1}^{100}$ odvojena nego je istovjetna sa stvarju. Sve konkretne, s osjećanjem srasle i upravo iz njega nikle pomisli o stvarih treba odbiti, odbaciti; u njih nije ništa bićna, ništa u istinu zbiljna (realna). Sámo abstraktno, od svega osjećanja odriešeno, i s toga čisto pojmovno mišljenje tako je podpuna prikaza bića i bivstva, da je čisti pojam upravo jednak bitku i bivstvu stvari. Zato, ako iz naših pomisli odbijemo sve konkretno, t. j. pojedinačno opažajno, osjećajno, ter tako imajući čisto (abstraktno) mišljenje, počnemo ${ }^{101} \mathrm{~s}$ najodlučenijim (najabstraktnijim) pojmom, možemo iz njega razviti neprekidan niz pojmovâ, /str. 98/ koji će u svojoj cjelokupnosti i u svom razvoju biti istovjetni s cjelokupnošću pravih bića i pravoga bitka ter razvitka svega svieta. Takovu, u bićnu jezgru svieta proničuću, spoznaju hoće tobože podati absolutna logika Hegelova; ona se i zove absolutnom zato, što tobože podaje absolutnu, posve dovršenu spoznaju svieta.

Osnovna načelna tvrdnja te logike jest: najodlučeniji (najabstraktniji) pojam, kao početak svih ostalih pojmova, razvija sam iz sebe, bez ikakve pomoći opažajnih, osjećanjem stvarnim nastalih pomisli, sveukupnost pojmova, dakle sveukupnost bića svega svieta.

\footnotetext{
96 samostalna : samostalnoga

97 prava : pravoga

98 izražava : izrazuje

99 podpun : podpuni

100 stvarî : stvarih

101 počnemo: počmemo
} 
Ali može se pokazati, $\alpha$ ) da absolutna logika onaj razvoj ne može izvesti inače nego samo tako, da proti svojoj načelnoj osnovnoj tvrdnji na odlučnih mjestih razvoja kriomice upotrebljava pomisli, koje su osjetnim opažanjem pojedinih stvari nastale; $\beta$ ) da je sav postup absolutne logike nelogičan, protivan neoborivim zakonom logike. Naše tvrdnje dokazat ćemo $(\operatorname{pod} \alpha$ i $\beta)$ u sliedećih dvaju paragrafih.

\section{$\S 2$.}

Koji je pojam najodlučeniji, i zato u nizu pojmova prvi, početni? Najjednostavniji su oni sudovi (izrieci), koji/str. 99/ se sastavljaju od njekoga subjekta i od takova predikata, koji tvrdi bitak subjektov, n. pr. Bog jest, čovjek jest (to su t. zv. existencijni sudovi); jednako jednostavne po smislu, premda po izrečnom ${ }^{102}$ obliku još jednostavnije, upravo najjednostavnije izreke jesu t. zv. bezsubjektne, n. pr. grmi: ta izreka tvrdi samo bitak osjeta iliti osjećanje grmljavine, a ne zna za nikakav subjekt grmeći. Ako u existencijnih sudovih odlučimo sve subjekte, to nam ostane sam predikat jest, koji tvrdi bitak. Dakle najodlučeniji i najjednostavniji pojam je pojam bitka; kad bismo odlučili, odbili i taj pojam, onda bi ostalo puko ništa.

Dakle najodlučeniji, najjednostavniji i s toga u nizu pojmova prvi i početni pojam je pojam bitka; taj čisti t. j. od svih subjekata posve odlučeni pojam bitka je isto, što sam čisti bitak.

Ali taj pojam čistoga bitka najdotjeranija je abstrakcija, od njega su svi subjekti odlučeni, odbijeni, a to će reći zanijekani; dakle čisti bitak je najdotjeraniji nijek (negacija), a taj se izjavlja ${ }^{103}$ riečju: ništo (t. j. ni što, nijedan subjekt nije tvrdjen, nego je svaki zanijekan). Dakle čistomu bitku kao savršenomu nijeku/str. 100/ istovjetno je puko, čisto ništo iliti čisti ne-bitak. Hegel veli: čisti bitak i čisto ništo jedno je te isto (»das reine Sein und das reine Nichts ist dasselbe«). Tako razvija prvi pojam - čisti bitak - samim svojim bivstvom sam iz sebe drugi pojam, t. j. svoj porječni nijek: čisti nebitak iliti čisto ništo.

No pošto je prvi pojam s drugim, čisti bitak s čistim nebitkom, po bivstvu istovjetan, to se oni ujedine u [\# jedan] treći pojam: u pojam bivanja iliti postajanja (das Werden); to će reći: postajanje sastavlja i ujedinjuje s nebitkom bitak. N. pr. dok biva (postaje) dan, on još nije, a i jest već; postajanje njegovo je postupno prelaženje iz nebitka u bitak, iliti spajanje nebitka s bitkom. Prvu trojnu skupinu tvore dakle u Hegelovoj logici ova tri pojma: 1. čisti bitak, 2. čisti nebitak, 3. postajanje. Ova trojnost sjeća Platonove nauke: ${ }^{104}$ po toj su ideje (t. j. čisti pojmovi) tò őv - bićje, a

\footnotetext{
102 izrečnom : izrječnom : izriečnom

103 izjavlja : izrazuje

104 Platonove nauke : na Platonovu nauku
} 


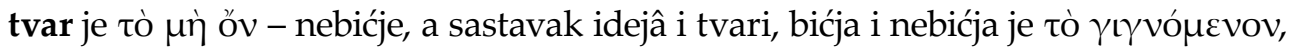
ono, što postaje, a to je sve pojavno stvarstvo; svaka pojavna stvar je spoj jedne ideje (kao vrstnoga pojma) s tvarju.

Pojam postajanja, taj treći pojam u prvoj skupini, izvilo je - tako tvrdi Hegel - / str. 101/ čisto mišljenje iz prvih dvaju pojma bez pripomoći ikakva stvarnoga osjećanja, opažanja; a taj je pojam najzbiljniji, najživotniji u svem svietu. No u istinu ne može čisto mišljenje toga pojma izviti iz pojma čistoga bitka i čistoga nebitka; čisti bitak je sam sobom [\# prazan] absolutan mir, podpuno nepromienljiv, a isto takav je i čisti nebitak sam sobom; njihovim sastavom ne može nići živo, pokretno, promjenljivo postajanje. Pojam postajanja doznan (dobiven) je osjetnim opažanjem zbiljnih promjenljivih pojavnih stvari, pak je odatle kriomce primetnut čistomu bitku i nebitku, a nije domišljen samim čistim mišljenjem. ${ }^{105}$ Jamačno je pomišljanje na $+E$ (ječnu munjinu) i na -E (niječnu munjinu), koje dvoje sastavom tvori ${ }^{106}$ živu iskru munjevnu, potaknulo Hegela, da iz ječnoga pojma »čisti bitak« i niječnoga pojma »čisti nebitak« izvije ječni pojam živa postajanja. Ali niječna munjina je nješto jednako zbiljno i po sebi ječno, kao što je ječna munjina; te ako sastavom toga dvojega ${ }^{107}$ niče živa zbiljna iskra, to ne dokazuje ništa za izvijanje pojma postajanja iz pojma čistoga bitka i čistoga nebitka. Iz ovih dvaju ${ }^{108}$ pojma čisto mišljenje ne bi nikad izvilo treći pojam »postajanje«, nego osjetno /str. 102/ opažanje, n. pr. toga pojava, ${ }^{109}$ kako postaje dan, stupa ovdje na mjesto čistoga bezopažajnoga mišljenja ter ovomu podmeće svoje doznaje. ${ }^{110}$

Tako je već na početku, kad iz prvih dvaju pojma hoće izviti treći, čisto mišljenje sámo sobom nemoćno, ono se sámo ne može ${ }^{111}$ doviti pojmu trećemu, pojmu postajanja, nego mu taj pojam prikučuje opažanje iliti izkustvo. ${ }^{12} \mathrm{~Pa}$ to se ponavlja ${ }^{113}$ diljem svega razvoja pojmovâ absolutne logike: ona može taj razvoj opravljati samo pomoćju izkustva, opažanja.

\footnotetext{
105 kriomce primetnut čistomu bitku i nebitku, a nije domišljen samim čistim mišljenjem : a ne iz čistoga mišljenja kriomce primetnut čistomu bitku i nebitku

106 tvori : daje

107 dvojega : dvoga

108 ovih dvaju : ova dva

109 n. pr. toga pojava, : ili

110 ovomu podmeće svoje doznaje : ovomu svoje doznaje podmeće

111 ono se sámo ne može : ono sámo ne može se

112 prikučuje opažanje iliti izkustvo : opažanje iliti izkustvo pozajmljuje

113 ponavlja : provlači
} 
A koje je $\mathrm{u}$ logici Hegelovoj metodno pokretalo, što no razvija prvi pojam $\mathrm{u}$ drugi, pak drugi u treći, pak treći u četvrti i t. d.? Početak sastavljaju ${ }^{114}$ ova tri pojma: 1. čisti t. j. najabstraktniji bitak, 2. čisti nebitak, 3. postajanje. Vidjesmo, da se prvi pojam, čisti bitak, razvije i upravo prometne u svoj nijek, u čisti nebitak, s toga, što čisti bitak, kao posve prazan, bezsubjektan, dakle kao bitak ni-čega, sam u sebi nosi svoj podpuni nijek; a zatim se prvi i drugi, ječni i niječni pojam, budući da su po svom bivstvu istovjetni, spoje i sastave u treći, u ječni pojam postajanja. /str. 103/ Dakle metodni postup je ovaj tročlani: najprije tvrdnja (pozicija), onda nijek njezin (negacija), zatim, radi nutarnje istote nijeka s tvrdnjom, sastav (sinteza) obojega u treći pojam ječan. ${ }^{115}$

Ovaj tročlani metodni postup ostaje i dalje diljem svega razvoja pojmovâ. Treći pojam, ječan, izvije opet iz sebe svoj niječni pojam, a taj četvrti s trećim, radi nutarnje istovjetnosti njihove, sastave se u peti, koji je opet ječan. I tako ide dalje, svagda u trojnih skupinah; a u svakoj je prvi pojam ${ }^{116}$ tvrdnja, drugi nijek te tvrdnje, a treći sastav (sinteza) njihov.

To možemo u ovoj podobi ${ }^{117}$ prikazati.

Prva trojna skupina je:,,$+- \neq$ (t. j. plus je ječan pojam, minus [\# je] nijek njegov, $a \neq$ je sastav obadvaju).

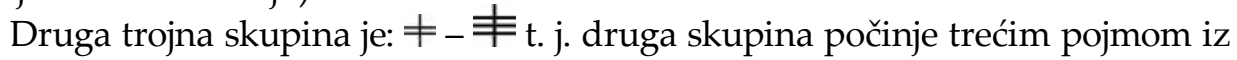
prve, taj se prometne u nijek svoj, a onda se nijek sastavi s početnim pojmom.

Treća trojna skupina je: jedinačna ${ }^{118}$ pojma, kojemu ${ }^{119}$ će biti ova podoba: ${ }^{120}$

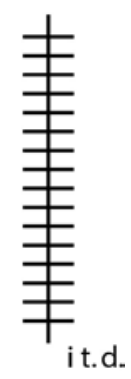

\footnotetext{
$\overline{114}$ Početak sastavljaju : Na početku imamo

115 ječan : ječni

116 a u svakoj je prvi pojam : u kojih svakoj prvi pojam je

117 podobi : slici

118 pojedinačna : pojedinačnoga

119 kojemu : komu

120 ova podoba : slika
} 
Ovo naše upodobljivanje ${ }^{121}$ pristaje posve dobro, jer Zeller u Poviesti njem[ačke] filosofije na str[ani] 793. veli: »logika je po Hegelu okostnica, kostur svieta«./str. 104/

Glavna pokretala u toj metodi, koju Hegel zove dialektičnom, jesu nijek, kojim se prvi pojam prometne ${ }^{122} \mathrm{u}$ drugi, i istovjetnost, po kojoj se prvi pojam $\mathrm{s}$ drugim sastavi u treći.

Pita se, odkud čisto, posve abstraktno mišljenje, dobiva nijek? Nijek može biti ili porječan (kontradiktoran), n. pr. bielo - nebielo, ili suprotan (kontraran), n. pr. bielo - crno [\# - crno je suprotan nijek bielu]. Pristanimo ${ }^{123}$ za čas, da sámo abstraktno mišljenje, bez pomoći stvarnoga opažanja, može iz ječnoga pojma »bielo« izviti njegov porječni nijek »nebielo«. Ali sam ječni pojam »bielo« ne može abstraktno mišljenje dobiti bez pomoći stvarnoga opažanja, kako ni pojam čistoga bitka nije dobiven inače nego iz stvarnih izreka: čovjek jest, zemlja jest i t. d., odlučivanjem svih stvarnih subjekatâ. ${ }^{124} \mathrm{~A}$ mogu li se dva porječna pojma, bielo i nebielo, ikad sastaviti i spojem svojim izviti treći pojam? Nikad. Izmira medju njima ${ }^{125}$ nema, oni se medjusobice izlučuju do vieka; poistovjetba i spojitba njihova nije moguća; kako da budu dva porječna pojma istovjetna? ${ }^{126}$ /str. 105/ Stoga njeki Hegelovci kažu, da ovaj nijek, koji razvije prvi pojam u drugi, nije porječan, nego je suprotan nijek: dakle primjer nije bielo - nebielo, nego bielo - crno. Ali pojam »bielo« ne može mišljenje bez pomoći stvarnoga opažanja prometnuti u njegov suprotak, $u$ crno, taj suprotak može se doznati ${ }^{127}$ samo opažanjem stvarnim.

Dakle Hegelova logika ima u nijeku, kao pokretalu i razvijalu pojmovâ, samo na izliku čisto misaono orudje, $\mathrm{u}$ istinu joj je stvarno opažanje podalo to orudje. Kako je Hegel mogao razviti, prometnuti čisti bitak u čisti nebitak, iznaći njihovu istotu? ${ }^{128}$ Samo tako, da je čisti bitak, koji je bezsubjektan, poredio sa stvarnim bitkom, koji ima za subjekt njeku stvar, n. pr. ČOVJEK jest - pak je našao, da je prema stvarnomu bitku onaj čisti bitak posve prazan, ništav, te je jednak ničemu, nebitku. Nikada ne bi abstraktno mišljenje samo, ne obazirući se, opažanjem, na stvarnu zbiljnost, naći moglo, da je čisti bitak po svom bivstvu isto, što je čisti nebitak. Tako na početku, pa i dalje, razvoj ječnoga pojma ${ }^{129} \mathrm{u}$ niječni logika ne može

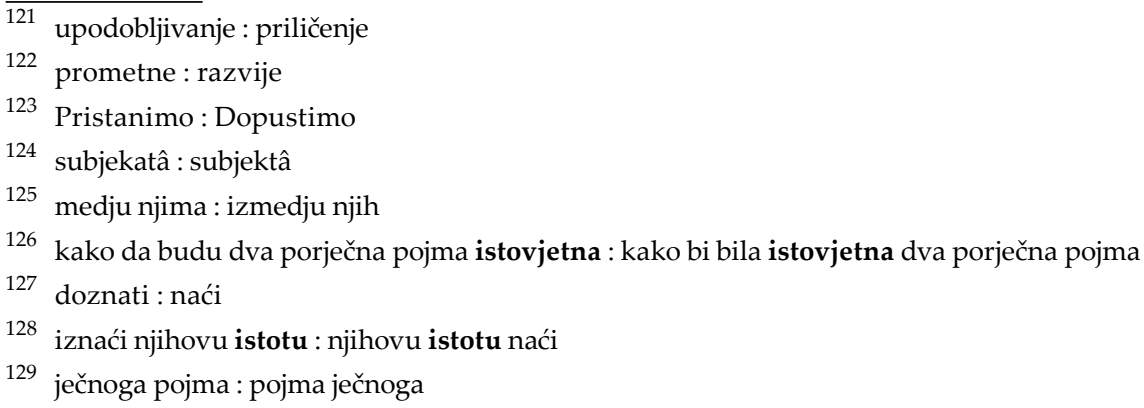


/str. 106/ čistim mišljenjem dobiti. Pokažimo to još na njekih pojmovih u razvoju logike Hegelove.

Pošto se je iz čistoga bitka i čistoga nebitka razvilo postajanje, razvija se iz ovoga obastanak. Sámo postajanje je vječito, nikad dovršeno, ${ }_{130}^{130}$ a ako se ono dovrši, i tim svoju bitnost, svoju vječitu nedovršivost zaniječe: onda postane obastanak iliti osobit $^{131}$ bitak (njem[ački]: Dasein). Prielazom postajanja u postanak i obastanak te spojem postajanja s obastankom postane nješto (Etwas) t. j. njeka (neodredjena) pojedinka $^{132}$ (njeki neodredjen individuj). A kako se dalje razvija to nješto, pravo reći pojam nječega? Ovako. Stvarni primjer pojmu nječega je pojedinačan krug.

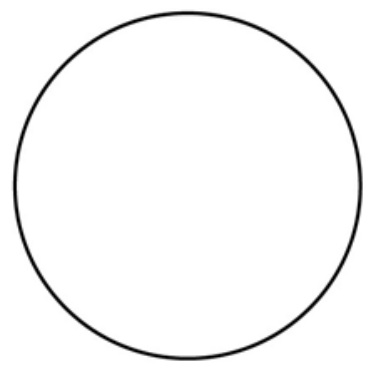

Nješto, - n. pr. taj krug - ima osobit bitak, obastanak svoj; dakle je ječno (pozitivno). Ali budući da je bitak nječega osobit, pojedinačan, to ima njegov bitak granicu svoju - n. pr. krugovu liku granica je obod njegov - ta granica tj. nijek obsežnijega bitka nječesova, n. pr. obod kao granica obsežnijega bitka krugova, pripada još i sam $\mathrm{k}$ bivstvu ${ }^{133}$ nječesa, pa tako prima nješto, $n$. pr. onaj krug, u sebe i svoj /str. 107/ vlastiti nijek. Bitak nječega $u$ njegovih granicah je samòbitak njegov (Ansichsein), a bitak nječega izvan njegovih granica je inòbitak njegov (Anderssein). Pošto granica nječega pripada i samome nječemu, n. pr. obod krugov pripada i samome krugu ${ }_{1}^{134}$ to je granicom ${ }^{135} \mathrm{u}$ samòbitak nječega uvučen i nijek toga samòbitka t. j. inòbitak, pa tako se samòbitak i inòbitak istovjete ${ }^{136} \mathrm{i}$ spajaju, iliti: nješto iz svoga samòbitka izvija inòbitak, a to će reći: mienja se. Zato je svako nješto, budući da je ograničeno iliti pojedinačno, ujedno neprestano promjenljivo.

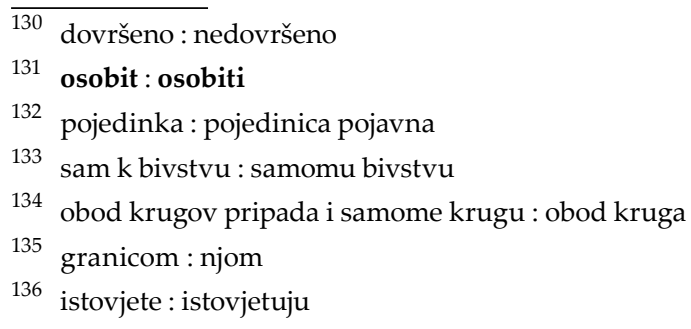


Tako je Hegel čisto misaonim razvojem samih čistih pojmova, bez ikakva obzira na stvarni sviet, dobio živi svjetovladni pojam neprestane promjene: svako se nješto ili svašto se mienja (»Táv no opažanje stvarno, da bi se došlo ${ }^{137}$ do pojma promjene; sámo čisto mišljenje ne može iz pojma »nješto « izviti ${ }^{138}$ pojam promjene.

Pomislimo, ${ }^{139}$ na primjer, dva kruga dodirna:

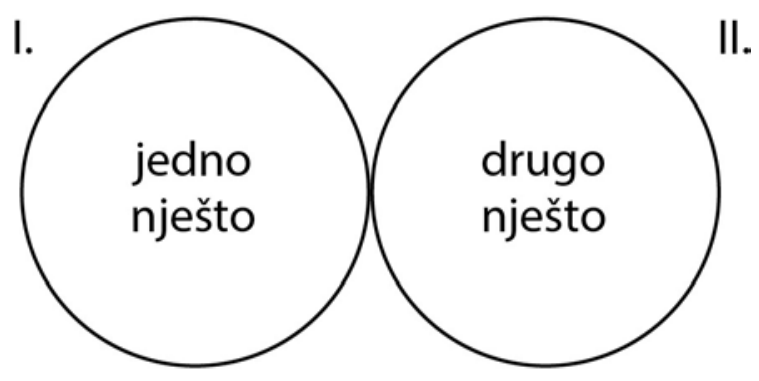

Doduše prvi krug je prama drugomu ini, a i drugi prema prvomu ini; ali zato, što /str. 108/ i jedan i drugi krug dobiva u toj relaciji, u tom poredjaju predikat »ini«, zato oni ipak nisu istovjetni, niti postaje prvi ${ }^{140} \mathrm{krug}$ drugim, t. j. ne promjenjuje se prvi krug u drugi, nego i jedan i drugi ostaje ${ }^{141}$ do vieka [\# svaki] ono, što jest.

Kako će se i kada će se I. krug zbilja promieniti u krug II.? Ako se gibaju; onda će I. krug zapremiti mjesto II ${ }^{\text {oga }}$ kruga. - Dakle gibanje, koje poznajemo samo po opažaju stvarnom, ${ }^{142}$ a koje pukim mišljenjem ne možemo stvoriti, podmećemo ovdje ${ }^{143}$ ako hoćemo iz nijeka jednoga nječega izvesti promjenu. Nije dakle istina, da se iz samoga nijeka jednoga nječega dade izvesti promjenjivanje njegovo kao bitna oznaka njegova bivstva. ${ }^{144}$

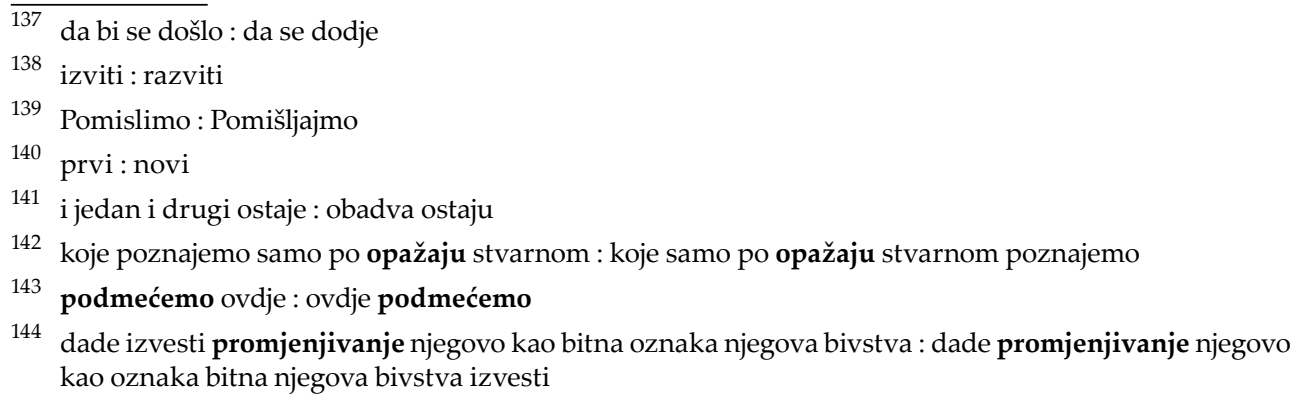


Snagu nijeka promotrimo u znamenitome za Hegelovu logiku suprotku ${ }^{145}$ duha i prirode. Hegel govori ovako: Pojam duha dade se ustanoviti samo tako, da se smotri medjusobica duha prema prirodi. ${ }^{146}$ Bitak ima samo misao, pojam. Priroda ima bitak, jer je i ona misao, pojam. Ali priroda je bezsebna (izvansebna) bezsvjestna misao, bezsvjestni pojam, budući pak da misao /str. 109/ ne može pravo biti bezsebna, izvansebna, nego samo prisebna (usebna), ${ }_{1}^{147}$ to se i vidi u prirodi vječita težnja, da bi skinula sa sebe oblik bezsebnosti, i da bi došla k sebi, da bi postala prisebna, usebna; ${ }^{148}$ t. j.: prostorna, razsežna, reć bi ${ }^{149}$ iz sebe razložena $i$ razvučena tvar teži uviek k svome središtu, a središte je matematička točka, t. j. podpuni nijek ${ }^{150}$ razsebnosti, raz-nosti, razloženosti. Sve u prirodi po zakonu gravitacije teži na to, da bi izašlo iz svoje razsebnosti, i da bi k sebi došlo, t. j. k središtu svome. ${ }^{151} \mathrm{Kad}$ bi se izpunila ta težnja prirode te bi se priroda skupila, uvukla ${ }^{152} \mathrm{u}$ svoje središte, onda bi ona prestala biti prostornom, razsežnom - prestala bi biti prirodom. Priroda je dakle bezsebna, razsebna i ukočena misao, koja se ne može u se uvući, k sebi doći, i prisebna biti. Misao, koja se porazsebila, porazsegla i ukočila u prirodu, ne može više k sebi doći $u$ prirodi, ali ona k sebi dolazi u duhu ljudskom; ljudski duh je priroda u se sabrana, k sebi došla [\# priroda]. Duh je dakle nijek prirodine bezsebnosti, izvansebnosti i razsebnosti, a tim je baš on konačni ${ }^{153}$ razvitak prirode, on je njezin završetak, on je istinito bivstvo prirode. Dok je priroda bezsebna, razsebna, /str. 110/ izvansebna, duh je priseban, useban; on ne teži istom $\mathrm{k}$ svojemu središtu, on ga je dosegao, on je samosvjestan, useban i oseban; duh je dakle misao, i to ne onakova, kakva je misao priroda - koju drugi misli -, nego on je misao, koja sama sebe misli, i koja druge mîsli mïslî (najpače misao prirodinu). Duh je sebi i subjekt i objekt mišljenja iliti i mislilac i mišljenik, dok je priroda samo objekt mišljenja, samo mišljenica, drugomu subjektu - duhu.

Eto od prirode bude nijekom nje same duh, iliti duh je nijek prirode, i to ne porječan nijek, koji bi prirodu samo uklanjao, ${ }^{154}$ nego suprotan koji mjesto pri-

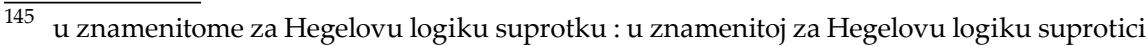

146 da se smotri medjusobica duha prema prirodi : da se medjusobica duha prema prirodi smotri

147 (usebna) : (usobna) : (prisobna)

148 da bi došla k sebi, da bi postala prisebna, usebna : da dodje k sebi, da postane prisobna, usobna

149 reć bi : kao

150 nijek : negacija

151 na to, da bi izašlo iz svoje razsebnosti, i da bi k sebi došlo, t. j. k središtu svome : tako, da izadje iz svoje razsebnosti, i da k sebi dodje, t. j. k središtu svomu

152 te bi se priroda skupila, uvukla : te da se priroda skupi, uvuče

153 konačni : završni

154 uklanjao : ništio : uništio
} 
rode postavlja nješto više, nješto ječno t. j. sama sebe. ${ }^{155}$ Pitamo sad, odkud absolutna logika dobiva to ječno (pozitivno) u pojmu duha? Predlozi izvan, pri, u, kod riečih »izvanseban«, »priseban «, »useban « označuju onu suprotnost: priroda je izvansebna (bezsvjestna), duh je priseban, useban (svjestan). Očito je ovako obilježena suprotnost doznana ${ }^{156}$ samo iz opažanja prostornih razlika:

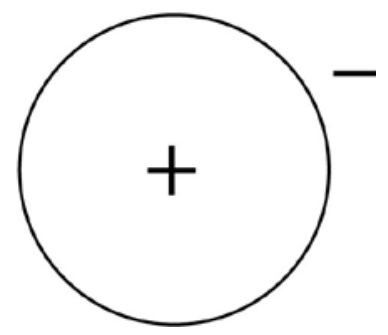

unutri, izvana, u i van, ili pri i izvan: »izvan sebe« biti, »pri sebi biti« (»dušu $u$ se povući«), to su očevidno prostorne suprotne oznake, koje se čistim mišljenjem /str. 111/ ne mogu izviti, ${ }_{157}^{157}$ već je Hegel podmetnuo čistomu mišljenju one ${ }^{158}$ opažajne prostorne suprotke. Ali još nješto. »Izvansebnost« prirode je njezina prostorna razsežnost, tvarna ukočenost: samo to može značiti »izvansebnost« prirode. Suprotnost toj izvansebnosti morala bi biti takodjer u području prostornosti; jer suprotak njekome ${ }^{159}$ pojmu može se nalaziti samo u istovrstnih pojmih: suprotak bjelini nije muklina, nego crnina, to jest suprotak njekoj šari (boji) može biti samo opet šara (boja), ${ }_{r}^{160}$ tako suprotak prostornoj izvansebnosti mora biti opet prostoran; dakle prisebnost, usebnost duha morala bi biti takodjer prostorna. Ali o duhu govorimo samo metaforno, ${ }^{161}$ da je priseban, useban, $u$ sebe uvučen; glede duha ne govorimo o prostornosti ${ }^{162}$ inače nego metaforom; dakle duh $^{163}$ ne može sastavljati s prirodom suprotak, kontrarnost, iliti: nije duh suprotan, nego je porječan (kontradiktoran) nijek prirode. Ako dakle [\# već] s Hegelom počnemo ovako: »duh je nijek prirode prostorne (razsežne)«, to treba da

\footnotetext{
155 prirode postavlja nješto više, nješto ječno t. j. sama sebe : prirode nješto višega, ječnoga t. j. duha postavlja

156 doznana : crpljena

157 koje se čistim mišljenjem ne mogu izviti : koje se iz čistoga mišljenja ne mogu izvaditi

158 one : te

159 njekome : njekomu

160 može biti samo opet šara (boja) : može samo opet šara (boja) biti

161 metaforno : metaforički

162 glede duha ne govorimo o prostornosti : kod duha o prostornosti ne govorimo

163 dakle duh : duh dakle
} 
nastavimo ${ }^{164}$ ovako: duh je neprispodobljii ${ }^{165} \mathrm{~s}$ prirodom, on nije završak prirode, nego je porjeka prirode; priroda je A; duh je non A; duh i priroda medju/str. 112/ sobom se izlučuju. ${ }^{166}$ Dakle glede nijeka kao orudja [\# svoga] kod izvadjanja drugoga pojma iz prvoga, pak četvrtoga iz trećega $i \mathrm{t}$. d., nalazi se absolutna logika ${ }^{167} \mathrm{u}$ ovoj dilemi: Ili je taj nijek porječan, kontradiktoran (A - non-A), ili je suprotan (kontraran) (A - Z); ako je porječan, to se izmir takovih dvaju pojma nikad ne može $\mathrm{e}^{168}$ naći, iz $\mathrm{A}^{\mathrm{a}}$ i non- $\mathrm{A}^{\mathrm{a}}$ ne može se nikad treći pojam izviti, dakle absolutna logika zastaje ${ }^{169}$ ukočena već pri trećem svom koraku, t. j. gdje iz $+A^{a}$ $\mathrm{i}-\mathrm{A}^{\mathrm{a}}$ hoće napraviti $\pm \mathrm{A}$. Ili je nijek ${ }^{170}$ samo suprotan (kontraran): onda se drugi pojam, suprotan prvome, ${ }^{171}$ ne da čistim mišljenjem izviti iz prvoga ${ }^{172}$ nego ga može podati sämo opažanje stvarno; dakle logika absolutna ne može već ni drugi pojam iz prvoga izviti173 čistim mišljenjem, nego se mora kriomce poslužiti opažanjem, kojega ona tobože ne potrebuje.

Drugo je pomagalo $u$ pokretu dialektične metode istota. 1. je pojam; 2. je protupojam; 3. iz istote njihove nastaje treći, viši pojam, koji sobom izmiruje $^{174}$ suprotnost pojma i protupojma; taj treći je nad njima dvjema, on je istota njihova, i s toga tek prava istina njihova. /str. 113/ Istota se po tom pričinja kao da je realna (sbiljna) jednota, realan (zbiljan) spoj pojma i protupojma; a nije, nego je samo abstraktna, umišljena istota njihova.

Vidjesmo gore: 1. čisti bitak, 2. čisti nebitak; iz istote njihove bude 3. bivanje (postajanje). Čisti bitak je prazan, bezsubjektan bitak, bitak ni-česa; zato je on isto što nebitak, a nebitak je isto što čisti bitak. To je podpuna logična (abstraktna) izjednačba. Ali da će odatle sbiljan (realan) spoj njihov nastati i živo bivanje nići, - to nije moguće; od čistoga bitka i ničesa ne mògu trećega pojma, bivanja, izviti onako, kako od kisika i vodika spojem bude voda. Ovakovu realnu jednotu mislio je Hegel da može izviti; ${ }^{175}$ iz $+x^{a} i-x^{a}$; ali od $+x^{a} i-x^{a}$ bude 0 (ništica), a nikad ne bude realni pojam »bivanje« iliti »postajanje «.

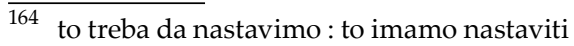

165 neprispodobljiv : neprispodobiv

166 priroda medju sobom se izlučuju : priroda se medju sobom izključuju

167 nalazi se absolutna logika : logika absolutna nalazi se

168 nikad ne može : ne može nikad

169 absolutna logika zastaje : logika absolutna stane

170 Ili je nijek : Ili nijek je

171 prvome : prvomu

172 izviti iz prvoga : iz prvoga izvaditi

173 izviti : izvaditi

174 sobom izmiruje : izmiruje u sebi

175 izviti : izvaditi
} 
U najznatnijoj misli svoga sustava, koja odredjuje medjusobicu konačnoga (ograničenoga) i nekonačnoga (neograničenoga), relativnosti i absolutnosti, upotrebljava ${ }^{176}$ Hegel načelo istote. Evo ovako:

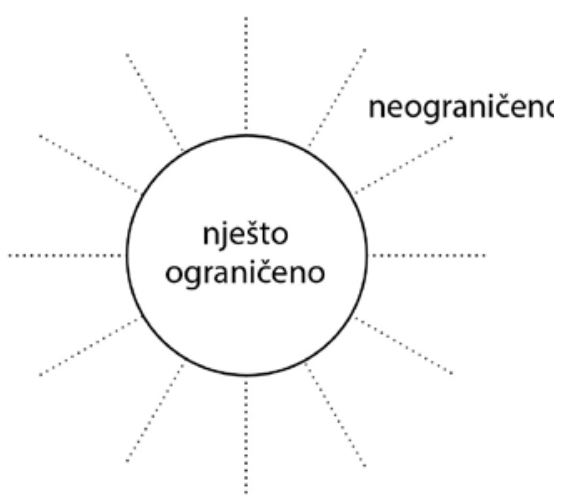

Nješto ograničeno ${ }^{177}$ ima izvan sebe, oko sebe neizmjerje neograničeno. Ali u brzo razabiramo, ${ }^{178}$ da je neograničeno istovjetno /str. 114/s [\# izmjernim] ograničenim. Jer [\# ono] neograničeno sámo ${ }^{179}$ je ograničeno [\# samim] onim ograničenim, koje u sebi kao mali kolut zatvara.

\section{znaci - stoje za neograničeni \\ [\# neizmjerni] prostor izvan $\mathrm{A}^{\mathrm{a}}$}

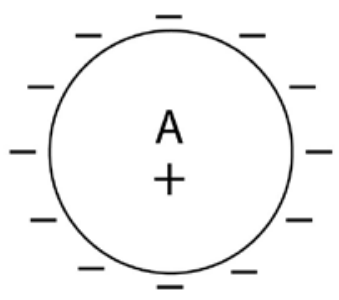

Ograničeno i neograničeno dakle je istovjetno: $\tilde{\varepsilon} v=\pi \tilde{\alpha} v$. U jednom je biću vasionstvo, a u vasionstvu je svako pojedino. Relativni duh postaje absolutnim, a absolutni bitkuje u pojedinih relativnih, t. j. bog je immanentan svietu, bog je u svietu, nije izvan svieta. To je Hegelov pantheisam. Ali Hegelova poistovjetba ograničenoga i neograničenoga netemeljit je postup. On umuje ovako. Onaj A,

\footnotetext{
176 relativnosti i absolutnosti, upotrebljava : relativnoga i absolutnoga, rabi

177 ograničeno : konačno

178 u brzo razabiramo : odmah vidimo

179 sámo : baš
} 
nješto izmjerno (ograničeno), ${ }^{180}$ graničeći s neizmjernim ukazuje sámo sobom na neizmjerno ter svojim obodom, svojom granicom [\# ono] uvlači u se bivstvo neizmjernoga; i opet obratno: neizmjerno, graničeći s izmjernim, uvlači u se to izmjerno, dapače [\# ono] sámo postaje izmjerno iliti ne-neizmjerno. Ali to umovanje Hegelovo ne valja; jerbo ${ }^{181}$ ono njegovo neizmjerno izvan $\mathrm{A}^{\mathrm{a}}$ sämo je tobože neizmjerno, ono je $\mathrm{u}$ istinu takodjer izmjerno kao što je i $\mathrm{A}$; dakle ovdje se ne istovjetuje relativno $\mathrm{s}$ absolutnim, nego se istovjetuje jedno relativno ${ }^{182} \mathrm{~s}$ drugim nerelativnim. A je li i to istovjetovanje dozvoljeno, je li moguće? je li moguće tako, da bi se realno, zbiljstveno spojilo oboje u pravu /str. 115/ neizmjernost, te ${ }^{183}$ bi prostor izvan kruga $\mathrm{A}^{\text {a }}$ provalio granice $\mathrm{A}^{\text {ove }} \mathrm{i}$ slio se $\mathrm{s} \mathrm{A}^{\text {om }}$, ili bi ${ }^{184} \mathrm{krug} \mathrm{A}$ razvalio svoju granicu i razlio se $\mathrm{u}$ prostor izvan svoje granice? Onda bi $\mathrm{u}$ istinu nastala prava neizmjernost, prava absolutnost; ali odkud $\mathrm{A}^{\mathrm{u}}$ i non- $\mathrm{A}^{\mathrm{u}}$ taj pokret [\# njihov], odkud njima ta realna, živa sila na jednoč? Ta $\mathrm{A}$ i non- $\mathrm{A}^{185}$ miruju, eto vidimo da miruju, i do vieka će, koliko je do njih samih, mirovati: iz čiste misli onaj ${ }^{186}$ pokret njihov ne nastade do vieka. Istovjetnost izmjernoga i neizmjernoga, relativnoga i absolutnoga, jest dakle ovdje puka ${ }^{187}$ izjednačba dviju mirujućih misli, a nije zbiljstvena spojitba, nije pronik absolutnoga u relativno, ni razmak relativnoga $u$ absolutno.

Pak zar mogaše i sve ovo, što govorasmo, izvodeći tobože istovjetnost ograničenoga $s$ neograničenim, nići ${ }^{188}$ iz čiste misli? Jamačno ne mogaše, nego iz pomišljanja opažanih prostornih razlika; pa kako mi pomažemo sebi zornimi kruzi, da shvatimo Hegela, bit će i on sämo pomišljanjem takovih zornih krugova došao na svoju [\# po]istovjetbu ograničenoga s neograničenim. Dakle: iz čistoga mišljenja ne nikoše ni prvi pojmovi ni protupojmovi ni izmirni pojmovi, ${ }^{189}$ nego svigdje krišom pomažu opažajne stvarne pomisli. ${ }^{190} /$ str. 116/

\footnotetext{
$\overline{180}$ nješto izmjerno (ograničeno) : izmjerno

181 jerbo : $u$ istinu $\mathrm{i}$

182 dakle ovdje se ne istovjetuje relativno s absolutnim, nego se istovjetuje jedno relativno : nije dakle ovdje istovjetovanje relativnoga s absolutnim, nego istovjetovanje jednoga relativnoga

183 neizmjernost, te : neizmjernost tako, da

184 ili bi : ili da bi

185 A i non-A : oni

186 onaj : taj

187 puka : samo

188 nići : nastati

189 mišljenja ne nikoše ni prvi pojmovi ni protupojmovi ni izmirni pojmovi : mišljenja prvi pojmi ni protupojmi, ni izmirni pojmi ne nastadoše

190 krišom pomažu opažajne stvarne pomisli : opažajne stvarne pomisli krišom pomažu
} 


\section{$\S 3$.}

Postup absolutne logike nelogičan je, t. j. on pravi one pogrješke $u$ doumljivanju, ${ }^{191}$ koje se zovu paralogismi. Zakoni, koje je Aristotel postavio o licih i načinih silogisma, priznaju se i danas. Pristaše najrazličitijih smjerova u filosofiji drže, da su oni zakoni neoborivi; samo Hegelova absolutna logika ne priznaje i navlaš vriedja te zakone. Evo tomu primjera u postupu njegove logike. Oblikovina (formula) drugoga silogismenoga lika ova je:

$$
\begin{aligned}
& P \pm M \\
& S \mp M \\
& S-P
\end{aligned}
$$

t. j. u drugom silogismenom liku zaglavak je svagda ${ }^{192}$ niječan, i svagda ${ }^{193}$ je jedan prednjak niječan $\mathrm{a}^{194}$ drugi ječan. Nikada se po drugom silogismenom liku ne može dobiti ječan zaglavak. Proti tomu grieši Hegelova absolutna logika, izvodeći po drugom silogismenom liku ${ }^{195}$ ječne zaglavke, i to iz takovih dvaju prednjaka, koji su obadva ječna. Hegelova logika radi onako, kao da bi iz dvaju suda:

\section{C je slovo, \\ 2. $\check{C}$ je slovo}

sljedovao zaglavak: dakle ${ }^{196} \mathrm{C}$ je Č [\# (?)]. Zar doista sljeduje? ${ }^{197}$ /str. 117/ Nikada! A ipak ovako (t. j. iz ječnih dvaju prednjaka dobivajući po $2^{\text {om }}$ silogismenom liku ječan zaglavak) često izvodi Hegelova absolutna logika u svom postupu, kadno za pokretalo ${ }^{198}$ rabi istovjetnost.

Evo tomu primjerâ. Prvi primjer:

1. Čisti bitak je najprazniji (najabstraktniji) pojam;

2. Ništa je najprazniji pojam;

3. Dakle: Ništa je čisti bitak, $\mathrm{i}^{199}$ obratno: čisti bitak je ništa.

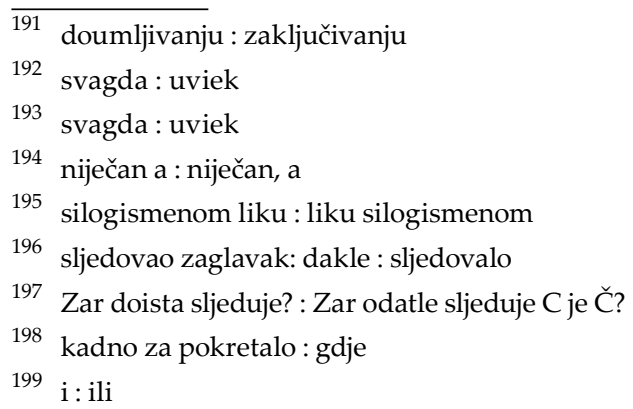


Drugi primjer. Hegelovac Rosenkranz u svojoj logici veli na jednom mjestu: izreka, da je bitak i nebitak isto, istinita je, jer ni bitku ni nebitku ne može se prireći nikakav predikat. Rosenkranz gradi dakle ovaj doumak:200

1. Bitak ne može imati predikata;

2. Nebitak ne može imati predikata;

3. Dakle nebitak je bitak, $\mathrm{i}^{201}$ obratno: bitak je nebitak.

Ovakovi pogrješni doumci ${ }^{202}$ (paralogismi) povlače ${ }^{203}$ se kao [\# h]rdjava nit po svoj absolutnoj logici. Hegel je dakako jasno razabirao tu svoju protivnost logičkim zakonom doumljivanja, ali se je pravdao tvrdnjom, da su ti zakoni zastarjeli i da ne vriede ništa. $\mathrm{No}^{204}$ to mu ne pomaže, kad svi drugi, počevši od Aristotela do Milla, kažu, da oni (stari) zakoni logički vriede, budući da ${ }^{205}$ naravski razum svakoga čovjeka svjedoči, ${ }^{206} d a$ vriede. Tko će onako izvoditi, ${ }^{207}$ da je $\mathrm{C}=$ Č? Hegel hoće. Ali Herbart je [\# prvi] temeljito dokazao ${ }^{208}$ logične pogrješke Hegelove; mnogi Hegelovci nisu ga htjeli poslušati, škodeći tako sami usavršavanju svoje nauke. ${ }^{209} /$ str. $118 /$

Treći primjer:

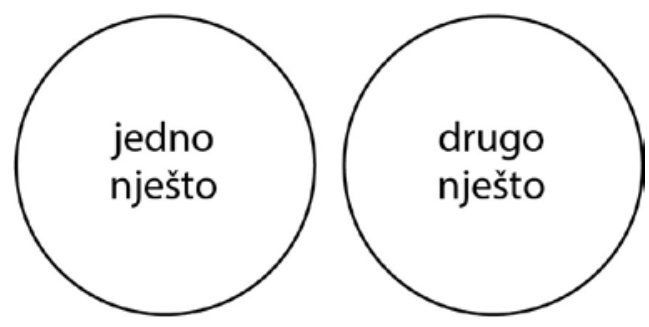

${ }^{200}$ ni bitku ni nebitku ne može se prireći nikakav predikat. Rosenkranz gradi dakle ovaj doumak : ni o bitku ni o nebitku ne može se nikakav predikat reći. Zaključak je eto ovaj

201 i : ili

202 doumci : zaključci

203 povlače : provlače

204 Hegel je dakako jasno razabirao tu svoju protivnost logičkim zakonom doumljivanja, ali se je pravdao tvrdnjom, da su ti zakoni zastarjeli i da ne vriede ništa. No : Je li Hegel opazio tu svoju suprotnost sa zakoni zaključivanja? Jest. On veli: ti zakoni ne vriede ništa. Ali

205 budući da : kad

206 svjedoči : kaže

207 izvoditi : reći

208 dokazao : dokazivao

209 svoje nauke : svojega sustava 
1. Jedno nješto je prama drugome nječemu INO;

2. Drugo nješto je prema jednome (t. j. s njegova motrišta drugome) ${ }^{210}$ nječemu INO;

3. Dakle je jedno nješto drugo nješto, t. j. jedno nješto promieni se $u$ drugo nješto.

Četvrti primjer:

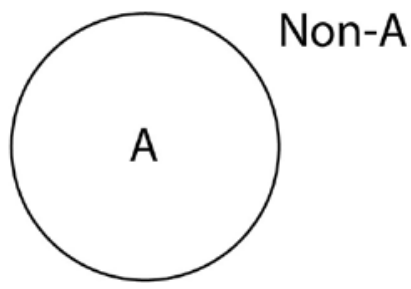

1. A je ograničeno;

2. Non-A je ograničeno;

3. Dakle: non-A je $\mathrm{A}, \mathrm{i}^{211}$ obraćeno: $\mathrm{A}$ je non-A, t. j. absolutno je istovjetno $\mathrm{s}$ relativnim, i opet relativno je istovjetno s absolutnim.

Herbartovac Exner u spisu: Die Psy[c]hologie der Hegeláiñschen Schule (Lipsko, 1842 i 1844, dvie svezke) ${ }^{212}$ dokazao je paralogisme u dialektičnoj Hegelovoj metodi tako tvrdo (suglasno s Trendelenburgom), da mu je pobjedu priznao i Hegelovac Weisse (u Zeitschrift für Philosophie und speculative Theologie, [\# god.] 1844, XIII. str. 258 i dalje, u razpravi: ${ }^{213}$ Die Hegeláiñsche Psy[c]hologie und die Exneráiñsche Kritik). Taj Weisse i I[mmanuel] H[ermann] Fichte spoznavši ${ }^{214}$ nedostatke Hegelova sustava, nastojahu ga prenoviti; ${ }^{215}$ ali bez uspjeha.

Glavne hegelovske logike jesu:

1. Werder: Logik als Commentar und /str. 119/ Ergänzung zu Hegels Wissenschaft der Logik. Berlin 1841.

2. Johann Ed[uard] Erdmann: Grundriss der Logik und Metaphysik. 1843.

3. Karl Rosenkranz: Wissenschaft der logischen Idee. Königsberg 1858 i 1859.

4. 4. Kuno Fischer: Logik und Metaphysik. 1852.

\footnotetext{
$\overline{210}$ motrišta drugome : gledišta drugomu

211 i : ili

212 dvie svezke : dva svezka

213 razpravi : članku

214 spoznavši : uvidjajući

215 prenoviti : reformirati
} 


\section{POPIS NAVOĐENIH I U ŠIREM SMISLU KORIŠTENIH DJELA}

Bain, Alexander. Logic / by Alexander Bain, LL. D., Professor of logic in the University of Aberdeen. London : Longmans, Green, Reader, \& Dyer, 1870. Part 1: Deduction.

Bain, Alexander. Logic / by Alexander Bain, LL. D., Professor of logic in the University of Aberdeen. London : Longmans, Green, Reader, \& Dyer, 1870. Part 2: Induction.

Bain, Alexander. Logique : déductive et inductive / par Alexandre Bain, professeur de logique à l'Université d'Aberdeen ; traduit de l'anglais par Gabriel Compayré , docteur ès lettres, professeur suppléant à la Faculté des lettres de Toulouse. Paris : Librairie Germer-Baillière, 1875. Tome 1: Déduction.

Bain, Alexander. Logique : déductive et inductive / par Alexandre Bain, professeur de logique à l'Université d'Aberdeen ; traduit de l'anglais par Gabriel Compayré , docteur ès lettres, chargé du cours de philosophie à la Faculté de Toulouse. Paris : Librairie Germer-Baillière, 1875. Tome 2: Induction.

Barac, Antun. Članci o književnosti. Zagreb : Binoza, Nakladni Zavod u Zagrebu, [1935]. [Moderni hrvatski pisci ; kolo 1, knj. 2.]

Bazala, Albert. Povjest filozofije / napisao dr. Albert Bazala. U Zagrebu : Izdala »Matica hrvatska «, 1909. Sv. 2: Knjiga druga: filozofija helenističko-rimska ; Knjiga treća: filozofija u srednjem vijeku ; Knjiga četvrta: novija filozofija do Kanta. [Poučna knjižnica »Matice hrvatske«; knj. 35/1.]

Bazala, Albert. Filozofijski portret Franje Markovića / napisao član dopisnik Dr. Albert Bazala ; primljeno u sjednici razreda juridičko-filozofičkoga od 5 julija 1921. // Rad Jugoslavenske akademije znanosti i umjetnosti. (1921), knj. 224 ; str. 221 - 312. Razreda historičko-filologičkoga i juridičko-filologičkoga [tj. juridičkofilozofičkoga] ; knj. 98.

Bazala, Albert. Filozofijski portret Franje Markovića. Zagreb : Institut za filozofiju Sveučilišta u Zagrebu, 1974.

Beneke, Friedrich Eduard. De veris philosophiae initiis / dissertatio inauguralis scripsit atque amplissimi philosophorum ordinis auctoritate pro summis in philosophia ordinis in Universitatis Berolinensi rite adipiscendis publice defendet d. IX. m. August. a. MDCCCXX hora XI. Fridericus Eduardus Beneke Berolinensis ; opponentibus H. Ritter, phil. doctore et in hac univ. litt. privatim docente, Henr. Abegg, iur. utr. doctore, Car. Bresler, theol. candidato. Berlin : Formis Brueschckianis, [1820].

Beneke, Friedrich Eduard. Neue Grundlegung zur Metaphysik / als Programm zu seinen Vorlesungen über Logik und Metaphysik dem Druck übergeben von Dr. F. E. Beneke, Privatdocenten an der Universität zu Berlin. Berlin ; Posen : In Commission bei E. S. Rittler, 1822. [Got.]

Benešić, Julije. Rječnik hrvatskoga knjižeonoga jezika : od preporoda do I. G. Kovačića / za tisak priredio i uvod napisao Josip Hamm. Zagreb : Jugoslavenska akademija znanosti i umjetnosti, Razred za suvremenu književnost ; Globus, 1985 - 1990. 12 sv. 
Benešić, Julije. Rječnik hrvatskoga književnoga jezika : od preporoda do I. G. Kovačića / urednici Milan Moguš , Anja Nikolić-Hoyt , Josip Vončina ; priredili za tisak Ivana Filipović Petrović, Alemko Gluhak, Bojana Marković, Anja Nikolić-Hoyt. Zagreb : Hrvatska akademija znanosti i umjetnosti, 2013. Sv. 13: S - spužvast.

Berg, Jan. From Bolzano's point of view / Jan Berg. // The Monist : an international quarterly journal of general philosophical inquiry. Vol. 83 (2000), No. 1 (January) ; str. $47-67$.

[Bolzano, Bernard.] Dr. B. Bolzanos Wissenschaftslehre : Versuch einer ausführlichen und größtentheils neuen Darstellung der Logik mit steter Rücksicht auf deren bisherige Bearbeiter / herausgegeben von mehren seine Freunde ; mit einer Vorrede des Dr. J. Ch. A. Heinroth. Sulzbach : In der J. E. von Seidelschen Buchhandlung, 1837. 4 sv. [Got.]

Botica, Stipe. Etički sadržaj naših narodnih poslovica u interpretaciji Franje pl. Markovića. // Civitas Crisiensis : radovi Zavoda za znanstvenoistraživački i umjetnički rad Koprivničko-križevačke županije u Križevcima = papers of the Institute for scientific research and artistic work of Koprivnica-Križevci County in Križevci. (2016), vol. 2 ; str. 23 - 33.

Brentano, Franz. Von der mannigfachen Bedeutung des Seienden nach Aristoteles / von Franz Brentano. Freiburg im Breisgau : Herder'sche Verlagshandlung, 1862. [Got.]

Brentano, Franz. Psychologie vom empirischen Standpunkte : in zwei Bänden / von Dr. Franz Brentano, o. ö. Professor der Philosophie an der K. K. Universität zu Wien. Leipzig : Verlag von Duncker \& Humblot, 1874. Band 1.

Burbidge, John W. Hegel's logic. // The rise of modern logic: from Leibniz to Frege / edited by Dov M. Gabbay, Departement of Computer Science, King's College London , Strand, London, WC2R 2LS, UK and John Woods, Philosophy Departement, University of British Columbia, Vancouver, BC Canada, V6T IZI and Departement of Computer Science, King's College London , Strand, London, WC2R 2LS, UK. Amsterdam ; Boston ; Heidelberg ; London ; New York ; Oxford ; Paris ; San Diego ; San Francisco ; Singapore ; Sidney ; Tokyo : Elsevier, North Holland, 2004. Str. 131 - 175. [Handbook of the history of logic ; Vol. 3.]

Carré, Meyrick H. Realists and nominalists / by Meyrick H Carré , Lecturer in Philososphy, University of Bristol. Oxford : Oxford University Press, 1946.

Compayré, Gabriel. Préface du traducteur. // Logique : déductive et inductive / par Alexandre Bain, professeur de logique à l'Université d'Aberdeen ; traduit de l'anglais par Gabriel Compayré , docteur ès lettres, professeur suppléant à la Faculté des lettres de Toulouse. Paris : Librairie Germer-Baillière, 1875. Tome 1: Déduction. Str. V - XL.

Copleston, Frederick Charles. A history of philosophy / Frederick Copleston, S. J. New York ; London ; Toronto ; Sydney ; Auckland : Image Books ; Doubleday, 1993. Vol. 2: Medieval philosophy. 
Copleston, Frederick Charles. A history of philosophy / Frederick Copleston, S. J. New York ; London ; Toronto ; Sydney ; Auckland : Image Books ; Doubleday, 1994. Vol. 7: Modern philosophy: from the Post-Kantian idealists to Marx, Kierkegaard, and Nietzsche.

Čehok, Ivan. Franjo Marković. // Novija hrvatska filozofija / Franjo Zenko. Zagreb : Školska knjiga, 1995. Str. 31 - 45. [Hrestomatija filozofije ; sv. 10.]

Despot, Branko. Filozofija u Hrvatskoj od osnutka Sveučilišta. // Prilozi za istraživanje hrvatske filozofske baštine. God. 22 (1996), sv. 1 - 2 (br. 43 - 44) ; str. 237 - 253.

Despot, Branko. Filozofija?. Zagreb : Demetra, 2000. [Demetra : filosofska biblioteka Dimitrija Savića ; sv. 50.]

Die Hegelsche Linke: Texte aus den Werken von Heinrich Heine, Arnold Ruge, Moses Hess, Max Stirner, Bruno Bauer, Ludwig Feuerbach, Karl Marx und Sören Kierkegaard / ausgewählt und eingeleitet von Karl Löwith. Stuttgart-Bad Cannstatt : Friedrich Frommann Verlag (Günther Holzboog), 1962.

Die Hegelsche Rechte: Texte aus den Werken von F. W. Carové, J. E. Erdmann, K. Fischer, E. Gans, H. F. W. Hinrichs, C. L. Michelet, H. B. Oppenheim, K. Rosenkranz und C. Rössler / ausgewählt und eingeleitet von Hermann Lübbe. Stuttgart-Bad Cannstatt : Friedrich Frommann Verlag (Günther Holzboog), 1962.

Dlustuš, Ljuboje. Dr. Franjo Marković : njegov život i rad. Osijek : Izvanredno izdanje Kluba hrvatskih književnika u Osijeku, 1915.

Dummett, Michael. Origins of analytical philosophy / Michael Dummett. London : Duckworth, 1993.

Erdmann, Johann Eduard. Grundriss der Logik und Metaphysik : für Vorlesungen / von Dr. Johann Eduard Erdmann, ordentlichem Professor der Philosophie an der Universität Halle-Wittenberg. 2., verbesserte Auflage. Halle : Bei Johann Friedrich Lippert, 1843.

Erdmann, Johann Eduard. Outlines of logic and metaphysics / by Johann Eduard Erdmann, late Professor of Philosophy in the University of Halle ; translated from the $4^{\text {th }}$ (revised) edition, with prefatory essay by B. C. Burt, Ph.D. London : Swan Sonnenschein \& Co. Limited ; New York : Macmillan \& Co., 1896.

Filipović, Ivan. Neues Wörterbuch der kroatischen und deutschen Sprache / zum Gebrauche für Juristen, Beamte, Lehrer, Handel- und Gewerbetreibende etc., nach den neuesten Quellen zusammengestellt von Ivan Filipović, unter Mitwirkung von Gj. Deželić, Lj. Modec und Gj. Simončić = [Novi rječnik hrvatskoga i njemačkoga jezika / za porabu pravnikâ, činovnikâ, učiteljâ, trgovaca, obrtnikâ itd., po najnovijih izvorih sastavio Ivan Filipović uz sudjelovanje Gj. Deželića, Lj. Modca i Gj. Šimončića]. Agram : Verlag von Leop. Hartmán's Buchhandlung = [U Zagrebu : Naklada knjižare Lav. Hartmána], 1875. 2 sv.

Filipović, Vladimir. Franjo Marković - rodoljubni pjesnik i učitelj filozofije : koliko u filozofiji Herbartovac?. // Prilozi za istraživanje hrvatske filozofske baštine. God. 8 (1982), sv. 1 - 2 (br. $15-16)$; str. $7-24$. 
Filozofijsko djelo Franje pl. Markovića : zbornik radova / priredio Stipe Kutleša. Zagreb : Matica hrvatska, 2016. [Zbornici i monografije.]

Filozofski leksikon / glavni urednik Stipe Kutleša ; pomoćnici glavnog urednika Filip Grgić, Željko Pavić ; leksikografske urednice Sanja Fabijanić, Mirjana Mataija ; strukovni urednici Goran Kardaš , Josip Oslić , Nenad Smokrović , Lino Veljak. Zagreb : Leksikografski zavod »Miroslav Krleža«, 2012.

Fischer, Kuno. Logik und Metaphysik oder Wissenschaftslehre : Lehrbuch für akademische Vorlesungen / von Dr. Kuno Fischer, Docent der Philosophie an der Universität zu Heidelberg. Stuttgart : C. P. Scheitlin's Verlagshandlung, 1852. [Got.]

Fischer, Kuno. System der Logik und Metaphysik oder Wissenschaftslehre / von Kuno Fischer. 2. völlig umgearbeitete Auflage. Heidelberg : Verlagsbuchhandlung der Friedrich Bassermann, 1865. [Got.]

Fries, Jakob Friedrich. System der Philosophie als evidente Wissenschaft / aufgestellt von Jakob Fries, D. und Privatdocent der Philosophie in Jena. Leipzig : Bey Johann Conrad Hinrichs, 1804.

Fries, Jakob Friedrich. System der Metaphysik : ein Handbuch für Lehrer und zum Selbstgebrauch / von Jakob Friedrich Fries, D. der Phil. und Med. Gr. H. S. W. Hofrath und ord. Prof. d. Phil. zu Jena, corr. Mitgl. d. königl. Akad. d. Wiss. zu München u. Berlin. Heidelberg : Bey Christian Friedrich Winter, 1824.

Fries, Jakob Friedrich. Die Geschichte der Philosophie dargestellt nach den Fortschritten ihrer wissenschaftlichen Entwicklung / von Jakob Friedrich Fries, Doctor der Philosophie und Medicin, Großherzogl. Sächs. Geh. Hofrath und ordentlichem Professor der Physik und Mathematik zu Jena, correspondirendem Mitglied der königl. Akademieen der Wissenschaften zu Berlin und München. Halle : Verlag der Buchhandlung des Waisenhauses, 1837 - 1840. 2 sv. [Got.]

Gilson, Étienne. Filozofija u srednjem vijeku / preveo Dušan Janić ; [priredio D. S. [tj. Dimitrije Savić]]. Zagreb : Demetra, 2011. Sv. 1. [Demetra : filosofska biblioteka Dimitrija Savića ; sv. 128a.]

Grabmann, Martin. Die Geschichte der scholastischen Methode / nach den gedruckten und ungedruckten Quellen dargestellt von Dr Martin Grabmann, Professor der Dogmatik am bischöflichen Lyzeum zu Eichstätt. Freiburg im Breisgau : Herdersche Verlagshandlung, 1909. Band 1: Die scholastische Methode von ihren ersten Anfängen in der Väterliteratur bis zum Beginn des 12. Jahrhunderts. [Pretisak. Berlin : Akademie-Verlag, 1988.]

Grabmann, Martin. Die Geschichte der scholastischen Methode / nach den gedruckten und ungedruckten Quellen bearbeitet von Dr Martin Grabmann , Professor der Dogmatik am bischöflichen Lyzeum zu Eichstätt. Freiburg im Breisgau : Herdersche Verlagshandlung, 1911. Band 2: Die scholastische Methode im 12. und beginnenden 13. Jahrhundert. [Pretisak. Berlin : Akademie-Verlag, 1988.]

Hegel, Georg Wilhelm Friedrich. Fenomelogija duha / preveo Viktor D. Sonnenefeld ; pogovor napisao Vladimir Filipović. Zagreb : Kultura, 1955. 
Hegel, Georg Wilhelm Friedrich. Phänomenologie des Geistes. Frankfurt am Main : Suhrkamp Verlag, 1970. [Werke / Georg Wilhelm Friedrich Hegel ; Band 3.]

Hegel, Georg Wilhelm Friedrich. Wissenschaft der Logik I. Frankfurt am Main : Suhrkamp Verlag, 1969. Teil 1: Die objektive Logik : erstes Buch. [Werke / Georg Wilhelm Friedrich Hegel ; Band 5.]

Hegel, Georg Wilhelm Friedrich. Wissenschaft der Logik II. Frankfurt am Main : Suhrkamp Verlag, 1969. Teil 1: Die objektive Logik : zweites Buch. Teil 2: Die subjektive Logik. [Werke / Georg Wilhelm Friedrich Hegel ; Band 6.]

Hegel, Georg Wilhelm Friedrich. Enzyklopädie der philosophischen Wissenschaften im Grundrisse (1830). Frankfurt am Main : Suhrkamp Verlag, 1970. Band 1: Erster Teil : die Wissenschaft der Logik : mit den mündlichen Zusätzen. [Werke / Georg Wilhelm Friedrich Hegel ; Band 8.]

Hegel, Georg Wilhelm Friedrich. Enzyklopädie der philosophischen Wissenschaften im Grundrisse (1830). Frankfurt am Main : Suhrkamp Verlag, 1970. Band 2: Zweiter Teil : die Naturphilosophie : mit den mündlichen Zusätzen. [Werke / Georg Wilhelm Friedrich Hegel ; Band 9.]

Hegel, Georg Wilhelm Friedrich. Enzyklopädie der philosophischen Wissenschaften im Grundrisse (1830). Frankfurt am Main : Suhrkamp Verlag, 1970. Band 3: Dritter Teil : die Philosophie des Geistes : mit den mündlichen Zusätzen. [Werke / Georg Wilhelm Friedrich Hegel ; Band 10.]

Hegel, Georg Wilhelm Friedrich. Enciklopedija filozofijskih znanosti / [preveo Viktor D. Sonnenfeld]. [2. izd.] Sarajevo : »Veselin Masleša«; Svjetlost, 1987. [Biblioteka Logos.]

Hegel, Georg Wilhelm Friedrich. Znanost logike. Zagreb : Demetra, 2003. Dio 1: Objektivna logika. Sv. 1: Nauk o bitku : (1832) / preveo Sulejman Bosto ; [redaktura Željko Pavić , Dimitrije Savić]. [Demetra : filosofska biblioteka Dimitrija Savića ; sv. 70a.]

Hegel, Georg Wilhelm Friedrich. Znanost logike. Zagreb : Demetra, 2003. Dio 1: Objektivna logika. Sv. 2: Nauk o bîti : (1813) / preveo Željko Pavić. [Demetra : filosofska biblioteka Dimitrija Savića ; sv. 70b.]

Hegel, Georg Wilhelm Friedrich. Znanost logike. Zagreb : Demetra, 2003. Dio 2: Subjektivna logika ili Nauk o pojmu : (1816) / preveo Željko Pavić. [Demetra : filosofska biblioteka Dimitrija Savića ; sv. 70c.]

Hegelovska desnica : [tekstovi iz djela F. V. Karovea, J. E. Erdmana, K. Fišera, E. Gansa, H. F. V. Hinrihsa, K. L. Mišlea, H. B. Openhajma, K. Rozenkranca i K. Reslera] / [izbor i uvod Hermana Libea ; preveo sa njemačkog Dušan Travar ; predgovor Kasim Prohić]. Sarajevo : IRO »Veselin Masleša«, 1980. [Biblioteka Logos.]

Hegelovska ljevica : [tekstovi iz djela H. Hajnea, A. Rugea, M. Hesa i B. Bauera] / [izbor i uvod Karla Levita ; preveo sa njemačkog Besim Ibrahimpašić ; predgovor Kasim Prohić]. Sarajevo : IRO »Veselin Masleša«, 1980. [Biblioteka Logos.]

Herbart, Johann Friedrich. Lehrbuch zur Einleitung in die Philosophie / von Johann Friedrich Herbart, ordentlichem Professor der Philosophie und Pädagogik auf der Universität zu Königsberg. Königsberg : Bey August Wilhelm Unzer, 1813. 
Hjelmslev, Louis. Prolegomena to a theory of language / translated by Francis J. Whitfield. Madison ; Milwaukee ; London : The University of Wisconsin Press, 1969.

Hjelmslev, Louis. Prolegomena teoriji jezika / prijevod Ante Stamać ; predgovor Mirko Peti. Zagreb : GZH, 1980. BibliotekaTeka.

Klaić, Vjekoslav. Dr. Franjo Marković / V. Klaić. // Vienac : zabavi i pouci. God. 16 (1884), br. 21 (24. svibnja) ; str. 335 - 337, br. 24 (14. lipnja) ; str. 384 - 386, br. 38 (20. rujna); str. $608-611$.

Kneale, William ; Kneale, Martha. The development of logic / by William Kneale , F.B.A. and Martha Kneale. Oxford : At the Clarendon Press, 1962. [Pretisak. 1971 (with corrections).]

Kovač, Srećko. Formalizam i realizam u logici : Franjo pl. Marković i Gjuro Arnold. // Prilozi za istraživanje hrvatske filozofske baštine. God. 18 (1992), sv. 1 - 2 (br. $35-36)$; str. $141-182$.

Kovač, Srećko. Die kroatische Philosophie des 19. Jahrhunderts, Čučić und Marković : ein Überblick. // Kroatische Philosophie im europäischen Kontext / Jure Zovko (Hrsg.). Sankt Augustin : Gardez! Verlag, 2003. Str. 93 - 110. [Hermeneutik im Gardez! ; Band 4.]

Kovač, Srećko. Logika u filozofiji Franje pl. Markovića. // Filozofijsko djelo Franje pl. Markovića : zbornik radova / priredio Stipe Kutleša. Zagreb : Matica hrvatska, 2016. Str. 57 - 73. [Zbornici i monografije.]

Kutleša, Stipe. Markovićevo nastojanje oko istraživanja hrvatske filozofije. // Filozofijsko djelo Franje pl. Markovića : zbornik radova / priredio Stipe Kutleša. Zagreb : Matica hrvatska, 2016. Str. 141 - 152. [Zbornici i monografije.]

László, Bulcsú. Neka pitanja strojnoga razumijevanja prirodnoga jezika. // Informacijske znanosti i znanje / uredili Slavko Tkalac, Miroslav Tuđman. Zagreb : Zavod za informacijske studije, 1990. Str. 11 - 31.

László, Bulcsú. Pabirci redničnoga i obavjèstnîčkôga pojmovlja oko razumnih sustava. // Obrada jezika i prikaz znanja / uredili Slavko Tkalac, Miroslav Tuđman. Zagreb : Zavod za informacijske studije, 1993. Str. $11-73$.

Marković, Franjo. Estetička ocjena Gundulićeva Osmana / napisao dr. Franjo Marković. U Zagrebu : Tisak Dioničke tiskare, 1880.

Marković, Franjo. Filosofijske struke pisci hrvatskoga roda s onkraj Velebita u stoljećih XV. do XVIII. / rektorski govor Dr. Franje Markovića prigodom instalacije dne 19. listopada 1881. U Zagrebu : Tisak Lav. Hartmana i družbe, 1882. [Pretisak. Prilozi za istraživanje hrvatske filozofske baštine. God. 1 (1975), br. 1 - 2 ; str. 255 - 279.]

Marković, Franjo. Filosofijski rad Rugjera Josipa Boškovića / čitao u skupnoj sjednici jugoslavenske akademije znanosti i umjetnosti dne 14. veljače 1887. pravi član dr. Franjo Marković. // Rad Jugoslavenske akademije znanosti i umjetnosti. (1887 - 1888), knj. 87, 88, 90 ; str. 543 - 716. [Život i ocjena djelâ Rugjera Josipa Boškovića / uspomeni prve stogodišnjice smrti njegove posvećuje Jugoslavenska akademija znanosti i umjetnosti.] 
Marković, Franjo. Etički sadržaj naših narodnih poslovica / čitao u sjednici filozofičko-juridičkoga razreda jugoslavenske akademije znanosti i umjetnosti dne 17. studenoga 1886. pravi član dr. Franjo Marković. // Rad Jugoslavenske akademije znanosti i umjetnosti. (1889), knj. 96 ; str. 167 - 227. Razredi filologičko-historički i filosofičko-juridički ; knj. 25.

Marković, Franjo. Razvoj i sustav obćenite estetike / napisao Dr. Franjo pl. Marković, sveučilištni profesor. U Zagrebu : Nakladom kr. hrv.-slav.-dalm. zemaljske vlade, 1903. [Znanstvena knjižnica što je izdaje kr. hrv.-slav.-dalm. zemalj. vlada, odio za bogoštovlje i nastavu. Razdio 2. Filozofijske i historijske nauke ; sv. 2.] [Pretisak. Split : Izdavačka radna organizacija LOGOS, 1981.]

Marković, Franjo. Logika / napisao Dr Franjo pl. Marković ; priredio S. Kovač. // Prilozi za istraživanje hrvatske filozofske baštine. God. 18 (1992), sv. 1 - 2 (br. 35 - 36) ; str. $247-258$.

Marković, Franjo. Vrsti sudova po njihovih oblicih / Franjo pl. Marković ; priredio Srećko Kovač. // Prilozi za istraživanje hrvatske filozofske baštine. God. 19 (1993), sv. 1 - 2 (br. $37-38$ ) ; str. $251-265$.

Marković, Franjo. Uvod u pedagogiku / [priredio Ivan Čehok]. // Novija hrvatska filozofija / Franjo Zenko. Zagreb : Školska knjiga, 1995. Str. 115 - 121. [Hrestomatija filozofije ; sv. 10.]

Marković, Franjo. Sustav općenite pedagogike / [priredio Ivan Čehok]. // Novija hrvatska filozofija / Franjo Zenko. Zagreb : Skolska knjiga, 1995. Str. 122 - 128. [Hrestomatija filozofije ; sv. 10.]

[Marković, Franjo.] Gimnazijska pedagogika Franje Markovića : (prvotisak prema izvornom rukopisu) / [priredio Ante Bežen]. // Napredak : časopis za pedagogijsku teoriju i praksu. God. 149 (2008), br. 3 (srpanj - rujan) ; str. 351 - 368.

Marković, Franjo. Etika / Franjo pl. Marković ; kritičko izdanje priredio i pogovor napisao Bojan Marotti. Zagreb : Matica hrvatska, 2016. [Biblioteka Parnas. Niz Filozofija.]

[Marković, Franjo.] Psihologijska podloga logici / [priredio Bojan Marotti]. // Filozofijsko djelo Franje pl. Markovića : zbornik radova / priredio Stipe Kutleša. Zagreb : Matica hrvatska, 2016. Str. 101 - 130. [Zbornici i monografije.]

[Marković, Franjo.] O riečih / [priredio Bojan Marotti]. // Civitas Crisiensis : radovi Zavoda za znanstvenoistraživački i umjetnički rad Koprivničko-križevačke županije $\mathrm{u}$ Križevcima $=$ papers of the Institute for scientific research and artistic work of Koprivnica-Križevci County in Križevci. (2016), vol. 2 ; str. 125 - 147.

Marotti, Bojan. Kako oriječiti misao? : o jednome Krstićevu prigovoru Šančevoj Filozofiji srednjega vieka. // Scopus : časopis za filozofiju Hrvatskih studija. God. 4 (2000), sv. 3 (br. $13-14$ ) ; str. $33-44$.

Marotti, Bojan. Pojam jezika u Kruna Krstića (članci 1940. - 1945.). // Prolegomena : časopis za filozofiju = journal of philosophy. God. 4 (2005), br. 1 (lipanj) ; str. 71 - 92.

Marotti, Bojan. Ciprino razumijevanje jezika. // Vrijeme metamorfoza: Uz Metamorfoze metafizike Marijana Cipre / priredio Damir Barbarić. Zagreb : Matica hrvatska, 2009. Str. 123 - 151. [Zbornici i monografije.] 
Marotti, Bojan. Rječnik hrvatskoga filozofskoga nazivlja. // Prilozi za istraživanje hrvatske filozofske baštine. God. 35 (2009), sv. 1 - 2 (br. 69 - 70) ; str. 123 - 180.

Marotti, Bojan. Kako je priređen Vitezovićev Lexicon Latino-Illyricum. // Lexicon Latino-Illyricum / Pavao Ritter Vitezović. Zagreb : ArTresor naklada, 2010. Sv. 2: Prijepis i obrada / rukopis kritički pročitale i rječnik upisale Zrnka Meštrović, Nada Vajs ; priredio i predgovor napisao Bojan Marotti. Str. V - CL. [Oživljena baština ; knj. 4, sv. 2.]

Marotti, Bojan. Uvod u Vitezovićev Lexicon Latino-Illyricum. Zagreb : ArTresor naklada, 2014. [Raspon ; knj. 2.]

Marotti, Bojan. Franjo pl. Marković. // Etika / Franjo pl. Marković ; kritičko izdanje priredio i pogovor napisao Bojan Marotti. Zagreb : Matica hrvatska, 2016. Str. 199 - 241. [Biblioteka Parnas. Niz Filozofija.]

Marotti, Bojan. O Markovićevim filozofskim rukopisima u arhivima HAZU. // Civitas Crisiensis : radovi Zavoda za znanstvenoistraživački i umjetnički rad Koprivničkokriževačke županije u Križevcima = papers of the Institute for scientific research and artistic work of Koprivnica-Križevci County in Križevci. (2016), vol. 2 ; str. $109-152$.

Marotti, Bojan. O pojmu znaka u Markovićevoj Logici. // Filozofijsko djelo Franje pl. Markovića : zbornik radova / priredio Stipe Kutleša. Zagreb : Matica hrvatska, 2016. Str. 75 - 139. [Zbornici i monografije.]

Marotti, Bojan. Nazivlje u Markovićevoj Etici. // Nova prisutnost : časopis za intelektualna i duhovna pitanja. God. 16 (2018), br. 3 ; str. 487 - 507.

Mill, John Stuart. A system of logic, ratiocinative and inductive, being a connected view of the principles of evidence, and the methods of scientific investigation / by John Stuart Mill. London : John W. Parker, West Strand, 1843. 2 sv.

Mill, John Stuart. System der deductiven und inductiven Logik : eine Darlegung der Principien wissenschaftlicher Forschung, insbesondere der Naturforschung / von John Stuart Mill ; in's Deutsche übertragen von J. Schiel. Dritte deutsche, nach der fünften der Originals erweiterte Auflage. Braunschweig : Druck und Verlag von Friedrich Vieweg und Sohn, 1868. 2 sv.

Papić Bogadi, Valentina ; Peklić, Ivan. Kazališna umjetnost i Franjo Marković, s posebnim osvrtom na recepciju u novinama na njemačkom jeziku = Theatres and Franjo Marković - special reference to theatrical reviews in German language newspapers. // Podravina : časopis za multidisciplinarna istraživanja = scientific multidisciplinary research journal. God. 11 (2012), br. 21 ; str. 77 - 97.

Parčić, Dragutin Antun. Vocabolario croato-italiano / compilato per cura di Carlo A. Parčić, Canonico Croato a Roma $=[$ Rječnik hrvatsko-talijanski / pripravio ga za tisak Dragutin A. Parčić , Hrvatski Kanonik u Rimu]. 3. ed. corretta ed aumentata. Zara : Tipografia editrice »Narodni List « = [U Zadru : Tisak i naklada »Narodnoga Lista «], 1901. [Pretisak. Zagreb : ArTresor studio, 1995. Oživljena baština ; knj. 1.] 
Pavletić, Krsto. Život i pjesnička djela Franje Markovića. U Zagrebu : Izdala Matica hrvatska, 1917.

Peklić, Ivan. Život i djelo Franje Markovića. Zagreb : Hrvatska akademija znanosti i umjetnosti ; Križevci : Zavod za znanstveno-istraživački rad Koprivničko-križevačke županije u Križevcima, 2014.

Prior, Arthur Norman. Historija logike / uredio A. N. Prior ; [preveo Branko Petrović ; pogovor Gajo Petrović]. Zagreb : Naprijed, 1970.

Rječnik hrvatskoga ili srpskoga jezika / na svijet izdaje Jugoslavenska akademija znanosti i umjetnosti. Zagreb : Jugoslavenska akademija znanosti i umjetnosti, 1880 - 1976. 23 sv.

Robert Zimmermanns philosophische Propädeutik und die Vorlagen aus der Wissenschaftslehre Bernard Bolzanos : eine Dokumentation zur Geschichte des Denkens und der Erziehung in der Donaumonarchie / eingeleitet und herausgegeben von Eduard Winter. Wien : Verlag der Österreichischen Akademie der Wissenschaften, 1975. Österreichische Akademie der Wissenschaften, Philosophisch-historische Klasse : Sitzungsberichte ; Band 299, Abhandlung 5. Veröffentlichungen der Kommission für Geschichte der Erziehung und des Unterrichts ; Heft 16.

Rosenkranz, Karl. Georg Wilhelm Friedrich Hegel's Leben / beschrieben durch Karl Rosenkranz ; mit Hegel's Bildniß, gestochen von K. Barth. Berlin : Verlag von Duncker und Humblot, 1844. Supplement zu Hegels Werken. [Got.]

Rosenkranz, Karl. Wissenschaft der logischen Idee / von Karl Rosenkranz. Königsberg : Verlag der Gebrüder Bornträger, 1858. Theil 1: Metaphysik. [Got.]

Rosenkranz, Karl. Wissenschaft der logischen Idee / von Karl Rosenkranz. Königsberg : Verlag der Gebrüder Bornträger, 1859. Theil 2: Logik und Ideenlehre. [Got.]

Saussure, Ferdinand de. Cours de linguistique générale / publié par Charles Bally, Albert Sechehaye ; avec la collaboration de Albert Riedlinger ; édition critique préparée par Tullio De Mauro. Paris : Payot, 1980. [Payothèque.]

Saussure, Ferdinand de. Tečaj opće lingvistike / uvod i komentar Tullio De Mauro ; prijevod s francuskoga i talijanskoga Vojmir Vinja ; predgovor hrvatskomu izdanju August Kovačec. Zagreb : ArTresor naklada ; Institut za hrvatski jezik i jezikoslovlje, 2000. [Posebna izdanja.] [Biblioteka Jezikoslovni temeljci ; knj. 3.]

Smith, Barry. Austrian philososphy : the legacy of Franz Brentano. Chicago ; LaSalle, Illinois : Open Court Publishing Company, 1994.

Šulek, Bogoslav. Hrvatsko-njemačko-talijanski rječnik znanstvenoga nazivlja : osobito za srednja učilišta = Deutsch-kroatische wissenschaftliche Terminologie = Terminologia scientifica italiano-croata / po nalogu visoke kr. dalm.-hrv.-slav. zemaljske vlade sastavio Dr. Bogoslav Šulek. U Zagrebu : Tiskom Narodne tiskare dra. Ljudevita Gaja, 1874 - 1875. 2 sv. [Pretisak. Zagreb : Globus, 1990. Biblioteka Rječnici.]

Švacov, Vladan. Franjo Marković. // T \& T : Theater \& Theorie = teatar \& teorija = theater \& theory. God. 1 (1995), br. 2 ; str. $27-47$. 
The rise of modern logic: from Leibniz to Frege / edited by Dov M. Gabbay, Departement of Computer Science, King's College London, Strand, London, WC2R 2LS, UK and John Woods, Philosophy Departement, University of British Columbia, Vancouver, BC Canada, V6T IZI and Departement of Computer Science, King's College London, Strand, London, WC2R 2LS, UK. Amsterdam ; Boston ; Heidelberg ; London ; New York ; Oxford ; Paris ; San Diego ; San Francisco ; Singapore ; Sidney ; Tokyo : Elsevier, North Holland, 2004. [Handbook of the history of logic ; Vol. 3.]

Tiberghien, Guillaume. Logique : la science de la connaissance / par G. Tiberghien, docteur en philosophie - professeur ordinaire à l'Université de Bruxelles. Paris : Librairie internationale ; Bruxelles ; Livourne ; Leipzig : A. Lacroix, Verboeckhoven et $C^{i e}, 1865$. Partie 1: Théorie générale de la connaissance : ses origines, ses lois, sa légitimité.

Trendelenburg, Adolf. Platonis de ideis et numeris doctrina ex Aristotele illustrata / scripsit Fridericus Adolphus Trendelenburg, philos. doct. Lipsiae : Sumtibus Frid. Chr. Guil. Vogelii, 1826.

Trendelenburg, Adolf. Die logische Frage in Hegels's System : zwei Streitschriften / von Adolf Trendelenburg. Leipzig : F. A. Brockhaus, 1843.

Trendelenburg, Adolf. Logische Untersuchungen / von Adolf Trendelenburg. Dritte vermehrte Auflage. Leipzig : Verlag von S. Hirzel, 1870. 2 sv.

[Ueberweg, Friedrich.] Friedrich Ueberwegs Grundriss der Geschichte der Philosophie der patristischen und scholastischen Zeit / herausgegeben von Dr. Matthias Baumgartner, ord. Professor der Philosophie an der Universität Breslau. 10., vollständig neu bearbeitete und stark vermehrte, mit einem Philosophen- und Litteratoren-Register versehene Auflage. Berlin : Ernst Siegrfied Mittler und Sohn, 1915. [Friedrich Ueberwegs Grundriss der Geschichte der Philosophie. Zweiter Teil : Die mittlere oder die patristische und scholastische Zeit.]

[Ueberweg, Friedrich.] Die patristische und scholastische Philosophie / herausgegeben von Dr. Bernhard Geyer. 12. Auflage : unveränderter Nachdruck der völlig neubearbeiteten 11. Auflage. Graz : Akademische Druck- u. Verlagsanstalt, 1951. [Friedrich Ueberwegs Grundriss der Geschichte der Philosophie. Zweiter Teil : Die patristische und scholastische Philosophie.]

Vitezović, Pavao Ritter. Lexicon Latino-Illyricum. Zagreb : ArTresor naklada, 2010. Sv. 2: Prijepis i obrada / rukopis kritički pročitale i rječnik upisale Zrnka Meštrović , Nada Vajs ; priredio i predgovor napisao Bojan Marotti. [Oživljena baština ; knj. 4, sv. 2.]

Vodnik, Branko. Franjo Marković : studija. // Savremenik : ljetopis Društva hrvatskih književnika. God. 1 (1906), knj. 2 ; str. 81 - 96, knj. 3 ; str. 161 - 178.

Werder, Karl. Logik : als Commentar und Ergänzung zu Hegels Wissenschaft der Logik / von K. Werder, Dr. und außerord. Professor der Philosophie an der Universität zu Berlin. Berlin : Verlag von Veit und Comp., 1841. Erste Abtheilung. [Got.] 
Zimmermann, Robert. Anthroposophie im Umriss : Entwurf eines Systems idealer Weltansicht auf realistischer Grundlage / von Robert Zimmermann. Wien : Wilhelm Braumüller, 1882.

Zeller, Eduard. Geschichte der deutschen Philosophie seit Leibniz / von Dr Eduard Zeller. München : R. Oldenbourg, 1873. [Geschichte der Wissenschaften in Deutschland : neuere Zeit ; Band 13.] [Got.] 
Summary

\section{Marković's Critique of Hegel's Logic}

The manuscript Logic of Franjo Marković (1845-1914), the first professor of philosophy at the restored University of Zagreb (1874), is kept in the Archives of the Croatian Academy of Sciences and Arts, viz. the autograph (XV 37/1), and six lithographed copies (XV 37/2, $a-f$ ), of which the most extensive one is $2 a$ (approximately 820 pages). Marković taught logic at the University for 32 years, from 1875 until 1907. The manuscript of Logic, roughly speaking, consists of two parts: the first is introductory, and the second part is entitled System of Logic. The first part is divided into seven, and the second part into eleven sections. The article discusses the sixth section of the first part, whose title is Reasons Against Absolute Logic (in 2a, pp. 94-119), in which Marković sets forth his criticisms of Hegel's logic. Firstly, the manuscript of Logic is described, and then Marković is placed in the philosophical and intellectual background of the second half of the $19^{\text {th }}$ century. Next, two substantial Marković's objections to Hegel are considered: first, it is not possible from one (most abstract) concept, which would be the beginning of all other concepts, to deduce the wholeness of concepts (and at the same time the totality of Being) without the help of ideas acquired by perception; and secondly, absolute logic itself is "illogical", i.e. contrary to the irrefutable laws of logic. Finally, it is concluded that Marković's criticism of Hegel's logic, which is actually metaphysics, is made exclusively from the logical point of view, because Marković does not accept Hegel's "conversion" of logic into metaphysics. It is emphasized Marković's intent to outline his philosophical position on Hegel, since many Hegel's opponents, whom Marković himself belongs to, are mostly reluctant to deal with Hegel's philosophy. The Appendix contains the transcription of the sixth section of the first part of Marković's Logic.

Keywords: Franjo Marković; logic; Georg Wilhelm Friedrich Hegel; critique of Hegel's logic; anti-Hegelianism; Robert Zimmermann; Friedrich Adolf Trendelenburg; Aristotelianisam; Franz Brentano; Austrian realism. 